


THE GENERATION OF INSECTS 


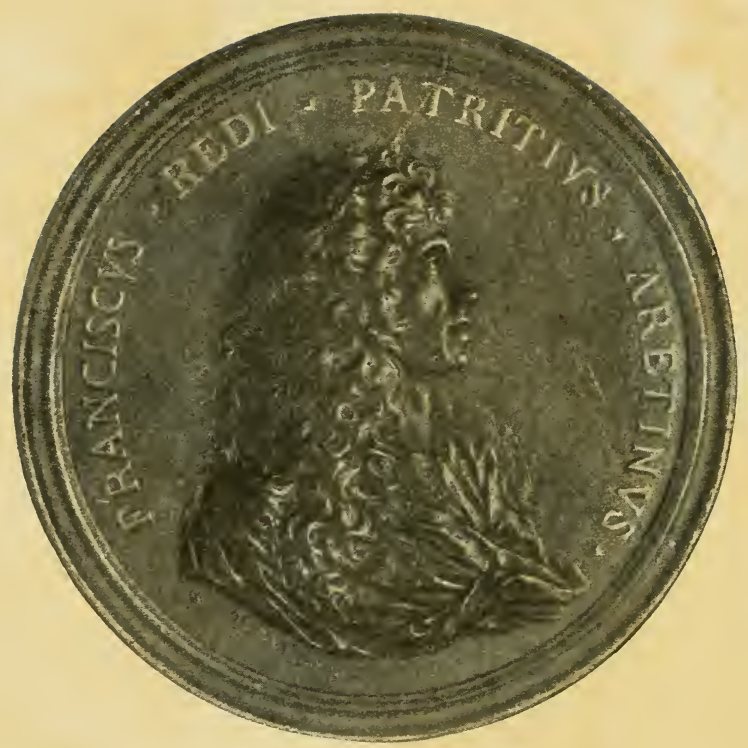

FRANCESCO REDI

From a medal dated 1684 in the Storer Collection of the Boston Medical Library. 


\title{
Experiments
}

\author{
ON THE

\section{Generation of Insects}

\author{
FRANCESCO REDI \\ OF AREZZO
}

TRANSLATED FROM THE ITALIAN EDITION OF 1688 BY MAB BIGELOW

\section{CHICAGO}

THE OPEN COURT PUBLISHING COMPANY

\section{LONDON AGENTS}

Kegan Paul, Trench, Trübner \& Co., L'T'D.

Ig09 
Copyright by

THE OPEN COURT PUBLISHING CO. 1909 


\section{CONTENTS}

INTRODUCTION.

PAGES

Life of Redi . . . . . . . . . . . . $5-8$

Significance of his work . . . . . . . . . 8-II

Bibliography . . . . . . . . . . . . . . I3

EXPERIMENTS ON the Generation of Insects.

Plea for the experimental method . . . . . . I9-2I

Historical review . . . . . . . . . . 2I-26

Redi's hypothesis . . . . . . . . . . . . $26-27$

Experiment on dead snakes . . . . . . . . . 27

Experiments with various meats . . . . . . . 30

Meat placed in sealed flasks . . . . . . . . 33

Discussion of Kircher's experiment . . . . . . 34

Air admitted to flask, but flies excluded by a net . . 36

Criticism of previous writers and description of an-

cient beliefs in the spontaneous generation of bees

$37-43$

Explanation of Biblical story of bees in carcass of lion 44-45

Digression on the habits of bees and wasps . . . . 46-50

History of opinions on the origin of scorpions . . 5I-53

Observations on scorpions . . . . . . . . . 53-62

Further observations disproving spontaneous generation $\quad 62-66$

Observations on spiders . . . . . . . . . 66-72

Experiments with cheese . . . . . . . . . 73-75

On insects appearing in fruits and vegetables . . . 75-76

Explanation of the belief that animals arise from mud and soil . . . . . . . . . . 76-80

Toads that appear with rain . . . . . . . 80

Refutation of the belief in organisms part plant and part animal . . . . . . . . . . 8I-85

On the mantis. Grafting experiment . . . . 85-89

Final conclusions on the breeding of flies and other wing insects in dead flesh, fish, plants, and fruits . 89-90

Occurrence of worms in living fungi . . . . . . 90

Liceto's corpuscular hypothesis . . . . . . . . 9I

Redi's belief in heterogenesis in living plants . . 92-94

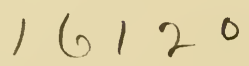




\section{CONTENTS}

PAGES

Galls and gall insects . . . . . . . . . . 94-95

On the argument that the lower cannot produce the higher . . . . . . . . . . . . 95

On the sensitiveness of plants . . . . . . . . 96-99

Fruit worms . . . . . . . . . . . . . . 99-102

Butterflies, their metamorphoses and egg laying . . 102-107

Parasites of cabbage butterfly . . . . . . . 107

Willow galls . . . . . . . . . . . . . I08-109

No other caterpillars produced by trees . . . . . IO9-II3

Internal parasites . . . . . . . . . . . . II3-II6

Lice and other external parasites . . . . . . II6-I25

Conclusion . . . . . . . . . . . . . . . 126

Plates . . . . . . . . . . . . . . . . I27-155

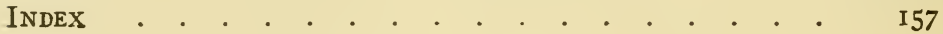




\section{INTRODUCTION}

The life of Francesco Redi centers in a period favorable to his fame. He was born in Arezzo, Tuscany, in 1626, sixteen years after the publication of Galileo's "Sydereus Nuncius" and six years before his "Dialogues on the Ptolemaic and Copernican Systems," at a time when the twenty century old authority of Aristotle was still undiminished.

The speculative philosophers Bruno, Campanella, Varini, and Kepler, all critics of Aristotle, prepared the way for the new Master, who was creator as well as critic. There was a third influence, however, to be considered: the Jesuits had monopolized all branches of learning, and had made Aristotle their own. His observations presented in the form of concrete and isolated facts, and especially his theories concerning the stability of the earth and the fixity of species, were not subversive of theological doctrine, hence the fathers invoked his name to clench every proposition. But the Mathematician put the Biologist's simple "qualities" together and on comparing them with his own ascertained "quantities," found new values, hence new truths. The combination of mathematical and natural science was formidable, especially when expressed in the vernacular; the Church, alarmed by Galileo's “ Dialogues," demanded his abjuration.

Redi was committed early to the care of the Jesuit Fathers. After leaving their school in Florence, he 
studied medicine and philosophy at the University of Pisa, whence he returned with his Doctor's degree to practice in Florence, where his family, meanwhile, had settled. His parents were of the provincial nobility, and his father, Gregory, a well-known physician, supported the family by his profession. Francesco had the good luck to be called to attend the Grand Duke after a hunting accident. Subsequently he became court physician and was much beloved by Ferdinand II and by his son and successor, Cosimo III. This prince did not resemble his magnanimous father, the founder of the Accademia del Cimento, for he did not protect the arts and sciences through love of them, but rather from vanity and a sense of his own importance. Cosimo was a bigot, whose mind was chiefly occupied in prosecuting religious offenders or in settling matters of etiquette. Small wonder that Swammerdam refused an invitation to this Court, or that Steno, his friend, who accepted it, soon afterwards abjured Protestantism. Redi's training admirably fitted him for this position, which was a difficult one; for besides his duties as physician and head of the Medicean laboratory, he was often commanded to negotiate minor diplomatic matters or requested to act as mediator when friction occurred between the Grand Duke and his son. He was obliged to follow the Court in its migrations to seaside and villa, forced to interrupt his own work, and to add to his troubles, his nephews (Redi was unmarried), who through his influence held lucrative positions, were often in difficulties of a compromising nature.

The favor accorded to Redi by Cosimo caused him to be courted by many learned men, and he unselfishly used his privileges for the benefit of his numerous friends, among whom were the poets Filicaja and Menzini, Bel- 
lini the physician, and Marchetti, mathematician and translator of Lucretius. Bellini wrote of him to Malpighi: "Everyone burns incense to the Idol."

Redi never failed in deference to the Jesuits. Father Segneri, the most celebrated orator of the day, was his close friend, and to Father Kircher, the founder of the collection in the Collegio Romano, is inscribed his report on "Various Natural Curiosities brought from India;" Redi even expressed esteem for Father Gottignes of Brussels, " a mathematician, who disliked algebra, and an astronomer, who contested Cassini's discoveries." This constant friendship for the Jesuits must have had a maleficent effect on our Author's mind, as it exacted blind faith and put a limit to his, logic. It is pleasanter to think of his relations with such scientists as Borelli and Magalotti, to the latter of whom the "Observations on Vipers" was written in epistolary form, and Carlo Dati, to whom the present work was addressed; all were of the Galilean school and members of the Accademia del Cimento, reorganized in 1657 by Leopoldo Medici, Ferdinand's brother, for the purpose of investigating the nature of things according to Galileo's experimental method. Redi was also a member of the Lincei, the earliest scientific academy, founded at Rome in 1603 , and an Arcadian, under the patronage of Queen Christina, of Sweden. He was arch consul of the famous Accademia della Crusca, created to preserve the purity of the Tuscan language, and aided in compiling the third edition of its dictionary.

Redi was a rare combination of naturalist and poet. As the latter, he is best known in Italy, where his writings are admired for their clearness and grace, and where his famous dithyramb on wine is still popular, being sold 
in penny prints in open stalls. This festive song describes Bacchus in the act of sampling the Tuscan vintages, which he praises and offers to Ariadne.

In a sequel to this composition, written in similar vein, Ariadne is ill from excessive potations, and tells her maidens to bring water from all the fountains of Europe, that her thirst may be quenched. From the equal justice done both subjects, it is apparent that the Author's mind was ever in equilibrium and that he appreciated the value of opposite things. In true Anacreontic spirit, he sings of the vivifying power of wine, and again he wisely lauds the healing virtue of water. Indeed Redi was the first to reintroduce the use of water in medical treatment, much to the disgust of his father, Gregory, who disliked Hippocratian remedies and preferred prescriptions "a mile long " after the Arabian fashion. Francesco believed with Galen that Nature possesses a healing power of her own, which the physician can only aid. Levi calls him "the Father of Tuscan medicine."

In the latter part of his life, Redi suffered from senile debility and other ailments, but he bore all patiently, and when a friend asked if he did not dread the approach of death, he replied that it was useless to do so, as he had never observed that death could be kept away through fear. He died suddenly in Pisa, March Ist, I697. Abbe Salvini writes of his end: "Death, his great enemy, whom he had so often fearlessly encountered and defeated, not daring to look into his face, approached him stealthily as he lay unconscious, and took him unawares, so he passed in an instant from sleep to eternal repose."

As has been said, Redi was able to delve deeply in the Aristotelean mine of thought by aid of Galileo's meth- 
ods; that he strictly belongs to the Galilean school, as many writers state, is hardly exact. He was not, nor were most pure biologists, led into the acceptance of an entirely physico-mechanical interpretation of Nature, as were Borelli, Descartes, and others, who carried the new teaching to the extreme, and ended in assuming that the human body is a machine, moved (Aristotle to the rescue!) by the pneuma, or spiritus.

Galileo had proved the falsity of Aristotle's theory of motion, but another doctrine of his lay open to discussion, namely: spontaneous generation, an ancient and persistent popular belief, which the father of biology had accepted, being unable to find any other origin for the lower animals. Paracelsus was an extreme exponent of the theory, attempting, it was said, to re-create human life. His reported experiments in this line excited the indignation of our orthodox author, who saw in them an attack on the mystery of Faith. Harvey, in spite of "omne vivum ex ovo," did not contradict the Greek philosopher, neither did Cesalpino of Arezzo, the discoverer, of the circulation of blood in the lungs. Giuseppe Aromatari of Assisi was the first to publish his disbelief in the time-honored tradition. In his treatise, "De Rabia Contagiosa" (Venice, r625), writing on the generation of plants, he insists that they arise from the seed, and that likewise all animals are born from the egg. Redi, however, was the first to prove this truth by experiments, that have been compared to those of Tyndall and Pasteur two hundred years later. Not content with merely recording what he perceived, he created new conditions in which the objects examined presented new aspects, reaching in this way a different viewpoint from that of the ordinary observer. Redi also possessed a 
singularly clear reasoning power, and a large measure of common sense, not an habitual concomitant of knowledge at the time. After disproving the generation of animals in dead matter, he logically tried to disprove it in a living medium, and in the case of insects arising from galls, he thought that the fly laid its egg in the slit twig, and that the usual transformation occurred. Unfortunately his observations, far from confirming his opinion, caused him to change it; that Nature prepared the gall for the insect seemed evident, so Redi, ever distrustful of himself, sacrificed his idea to that of Aristotle, acknowledging the creative power of the spiritus. This error was subsequently corrected by Redi's pupil, Vallisneri, who continued his investigations.

The "Esperienze Intorno alla Generazione degl' Insetti" gives the circumstances and methods by which Redi reached his important conclusions and is the work by which he is best known to men of science. Many editions prove that it was fully appreciated by his contemporaries: the book appeared in I668, and in 1688 reached the fifth edition, the one from which the following translation was made. A Latin version was published in Amsterdam in $167 \mathrm{I}$ and was reprinted as Part Ist of a larger work, "De Insectis," in I686. Pouchet ( 1859 ) mentions a French translation: "Collection Academique," Tome VI. The title of the work gives little hint of its varied contents. It is a formal letter grown into a book showing the attitude of seventeenthcentury Italians towards their surroundings, and affording a clear insight into their conception of Nature. The opinions of priests, philosophers, and poets of the period, on natural phenomena of perennial interest, are here set down with grave simplicity enlivened by occasional hu- 
morous comment, and many elaborate quotations from the classics are inserted as proof or refutation of theories advanced.

To the student of the history of biology, the book is a milestone marking the beginning of a great epoch. It records the first, and therefore the most important, statement supported by experimental evidence of that great generalization named by Huxley the theory of biogenesis, a theory, which in its application, has probably been of more benefit to mankind than any other result of scientific investigation.

The Translator. 


\section{TRANSLATOR'S NOTE}

This work is indexed and revised by

Dr. Robert P. Bigelow 


\section{BIBLIOGRAPHY}

Aristotle - History of Animals.

Cuvier, G-Histoire des sciences naturelles.

FABRoN I - Vitae Italorum Illustrium.

GoRANI - Elogi di due illustri scopritori italiani (unable to procure).

Imbert, Gaetano - F. Redi, Uomo di Corte e Uomo privato, N. Antologia, October, 1895 .

“ “ F. Redi, Cenni Biografici, nel Practico (out of print).

JOURDAN - Biographie médicale.

Nicéron - Mémoires, II I Vol. Io (unable to procure).

Pouchet, F. A.- Hétérogénie, ou traité de la generation spontanée, basé sur de nouvelles expériences, Paris, 1859.

RadL, E.-Geschichte der biologischen Theorien. Teil I, Leipzig, I905.

REDI, F.- Osservazioni intorno alle vipere, Firenze, I664.

“ “ Esperienze intorno alla generazione degl' insetti, Firenze, I668.

“ “ Lettera sopra alcune opposizioni fatte alle sue osservazioni intorno alle vipere, Firenze, I670.

“ “ Esperienze intorno a diverse cose naturali e particolarment a quelle che ci son portate dell' Indie, Firenze, I67I.

“ " Lettera intorno alla invenzione degli occhiali, Firenze, 1678.

" " Osservazioni intorno agli animali viveni che si trovano negli animali viventi, Firenze, I684.

“ " Consulti medici, Firenze, I726.

“ " Lettere di Redi. Ed. 2, Firenze, I779-1795. 3 Vols.

Salvini - Vite degl' Arcadi.

Settembrini, Luigi - Lezioni di letteratura Italiana, Vol. 2, Napoli.

Thompson, J. A.- Science of Life, 1899.

Tiraboschi - Storia della Letteratura Italiana, Vol. 8. 



\section{ESPERIENZE Intorno alla Generazione}

\section{DEGL'INSETT I F A T T E}

DA FRANCESCO REDI Gentiluomo Aretino, e Accademico della Crufce $E$ da Luiscritte in una Lettera ALL' ILLVSTRISSIMO SIGNOR

\section{A R L D A TI. Quinta Imprefsione.}

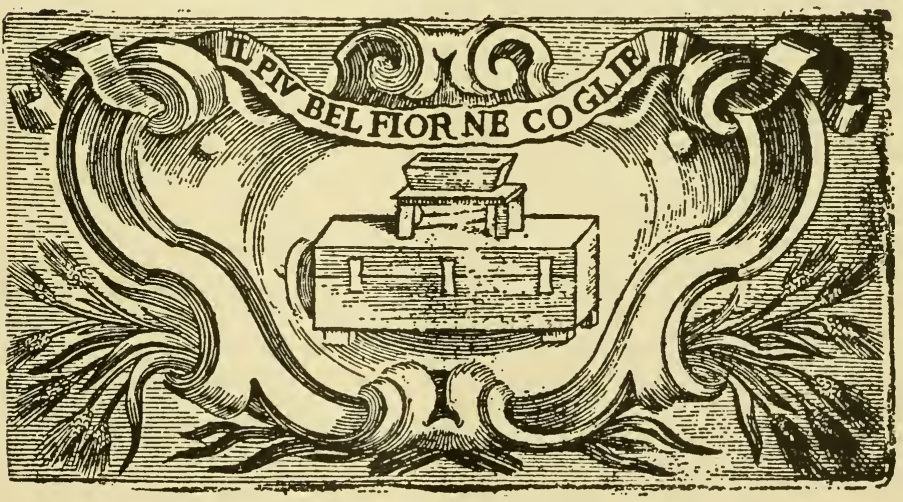

IN FIRE NZ E. MDCLXXXVIIT.

Nella Stamperia de Piero Matins, all Infegaa del Lion d'Oio. CONZICEIJ'A DE'SVTERIOLL. 



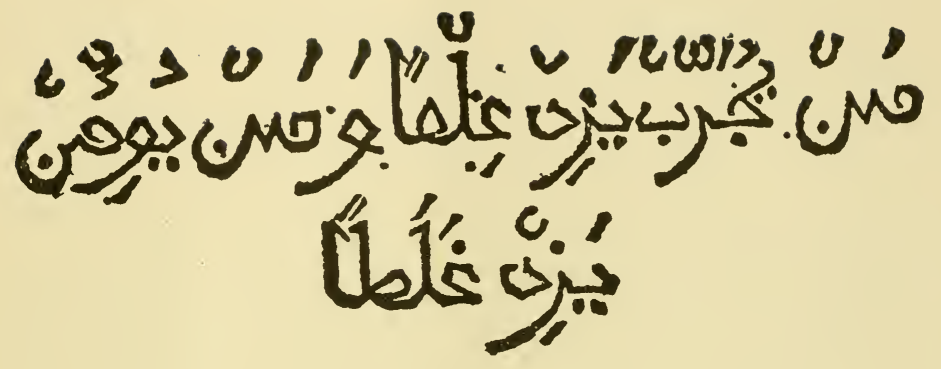

Experiment adds to knowledge,

Credulity leads to error.

Arab proverb, Erpenius, 57. 
Nature is nowhere to be seen to greater perfection than in the very smallest of her works. For this reason then, I must beg of my readers, notwithstanding the contempt they may feel for many of these objects, not to feel a similar disdain for the information I am about to give relative thereto, seeing that in the study of nature, there is none of her works that is unworthy of our consideration.

Pliny. ${ }^{1}$

1 Trans. of Bostock and Riley.

I 8 


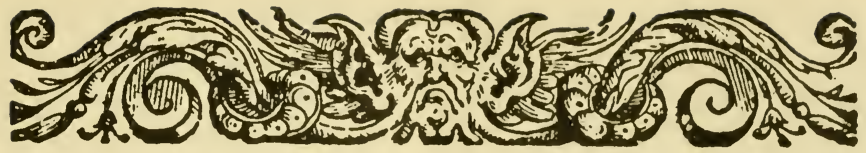

\section{SIR:}

There is no doubt that the senses were given to Reason by the Supreme Architect as aids to the better comprehension of natural things. They are like windows or doors through which she may look out on those things, or through which they may come in and make themselves known. Still better said: the senses are scouts, or spies, that seek to discover the nature of things, and report these observations to Reason within, who passes judgment on everything, describing with more or less clearness and precision, according to the validity, alertness, and accuracy of her informers. Hence it is that in order to verify observations, we frequently approach or recede from the object that we wish to examine, change its position or its light, and perform many other actions relating not only to the sense of sight, but also to those of hearing, smell and touch. In fact, no one of the slightest intelligence would attempt to exact judgment from Reason in any other way than this. Therefore, I believe Nature could not possibly choose any more useful gift for man than his five perfect senses. It is evident that a man searching for the truths of Natural History would go far astray if he did not keep his senses clear, for Reason, if set to work on a superficial report of the senses, would render a hasty and faulty verdict. Thus it happens that even young men new to the schools hold this opinion, which is but common sense, 
and has been stated by wise men of early days, who in philosophical matters were singularly in advance of their time. Among these, that great genius who knew everything and could write wonderfully well on all subjects, said in the second canto of Paradiso: ${ }^{1}$

Somewhat she smiled; and then, "If the opinion of mortals be erroneous," she said,

"Where'er the key of sense doth not unlock,

Certes the shaft of wonder should not pierce thee

Now, forasmuch as following the senses,

Thou seest that the reason has short wings."

But, if the senses do not do their duty, if they do not obtain correct information of what is happening in $\mathrm{Na}$ ture and thus do not aid Reason, is it strange that she should make but uncertain progress, now hastening forward impetuously, now retarded by fallacy and caught in the net of error? Hence, though my philosophical studies have been pursued with more zeal than profundity, I have nevertheless given myself all possible trouble and have taken the greatest care to convince myself of facts with my own eyes by means of accurate and continued experiments before submitting them to my mind as matter for reflection. In this manner, though I may not have arrived at a perfect knowledge of anything, I have gone far enough to perceive that I am still entirely ignorant of many things the nature of which I supposed was known to me, and when I discover a palpable falsehood in ancient writings or in modern belief, I feel so irresolute and doubtful of my own knowledge that I scarcely dare attack it without first consulting some

1 The Dante quotations in this work are from Longfellow's versions. All other extracts from Italian verse are Englished by the translator. 
learned and prudent friends. Thus having recently made many experiments especially in regard to the origin of those living creatures considered, to the present day, by all schools to have been generated by chance, that is spontaneously, without paternal seed; and being distrustful of myself, but still desirous of submitting the results of my labors to other minds, it occurred to me that I might have recourse to you, Signor Carlo, as you have graciously given me a place among your closest friends. Your great knowledge fortified by philosophy and nobly adorned with varied erudition is admired by all men of learning, and is the pride of Tuscany, who envies neither Latium her Varros, nor Greece her Plutarchs. Therefore I beg you to take the trouble to read this letter in your leisure moments and to give me your sincere opinion of it, together with your friendly advice and wise counsel, by the aid of which I shall be enabled to remove all superfluous and trivial matter and to add whatever may be necessary.

"Perchance I may with greater diligence And patient study yet perfect this work."

Many have believed that this beautiful part of the universe which we commonly call the earth, on leaving the hands of the Eternal, began to clothe itself in a kind of green down, which gradually increasing in perfection and in vigor, by the light of the sun and nourishment from the soil, became plants and trees, which afforded food to the animals that the earth subsequently produced of all kinds, from the elephant to the most minute and invisible animalcule. But the Earth, not content with producing dumb animals, desired the glory of being the Mother of Man. Hence, we are told by Lactantius that 
the Stoics asserted that human beings sprang forth from the soil of hill and plain like sprouting mushrooms. It was the general belief that they did not originate everywhere, but arose in some special place or country; hence the Egyptians, the Ethiopians, and the Phrygians gave the credit to their own lands, and the Arcadians, Phœnicians, and inhabitants of Attica put forth their claims. The Athenians, as a sign that the fathers of the human race originated in Greece (being born from the soil direct as even now grasshoppers are supposed to be born) wore golden ornaments in the hair fashioned like the grasshopper. But whatever may have been the country of origin, according to the teaching of Archelaus, a pupil of Anaxagoras, light, arid soil would not do nor would a mere sand bank serve the purpose of creation. It was necessary that the ground should be rich, warm, and capable of germination, whereupon a milky substance would be produced forming the first food of man and beast.

Those creatures living in the early days of the world were, according to Empedocles and Epicurus, born all at once, hastily and in disorder from the womb of Earth, still unused to motherhood. Such haphazard generation resulted in great confusion; some animals were born without mouths and without arms, others without eyes and without legs; some creatures with monstrous grafting of hands and feet tumbled about headless; still others were seen with a human head and the body of a beast; others had foreparts of beasts and the nether limbs of man; and certain ones were perhaps made in such guise as the poets describe the Minotaur of Crete, the Sphinx, the Chimera, the Siren, and winged horse of Perseus, or like the Atlante of Corena described by Ariosto: 
“Nature's own work, no artificial steed, His dam a mare, a griffin fierce his sire Who 'queathed his plumage and his wings, indeed His head and fore feet and the beak entire.

In other parts he to the mare came nigher; Fleet as the wind was Hyppogriff in speed."

But at last the great mother, perceiving that such monstrosities were neither good nor likely to endure, and having become more expert in the art of generation, succeeded in producing men and animals according to their species. Democritus bears witness that men first appeared in the form of small worms, which little by little assumed human shape; or, as Anaximander relates, on escaping from the womb of Earth they were enveloped in a kind of rough, spiny skin, not unlike the burr of a chestnut. After a long period of fertility, during which many monstrous and marvelous generations were brought forth, the Earth Mother became at last exhausted and sterile and lost her power of producing men and the larger animals, still she retained enough vigor to bring forth (besides plants that are presumed to be generated spontaneously) certain small creatures such as flies, wasps, spiders, ants, scorpions, and all the other ter-

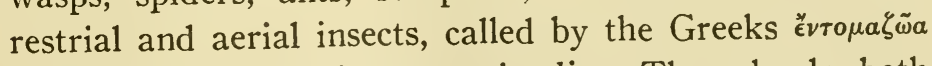
and by the Latins, insecta animalia. The schools, both ancient and modern, all agree in this, and constantly teach that the Earth has continued to produce these creatures and will produce them so long as she exists. They do not, however, agree as to the manner in which these insects are generated, nor how life is communicated to them; for they say that not only does the Earth possess this occult power, but that it is possessed by all animals living and dead, also by all things produced from the 
Earth, and finally by those which are about to decay and return to dust. Hence others have claimed putrefaction itself to be the all-potent cause of generation, and still others, natural heat. Many additional causes have been adduced, conforming to the divers modes of thought of different sects, who speak of active and efficient forces, the world soul, so to say - the spirit of the elements, ideas, the heavens, their light and motion, and higher influences. Nor was there lacking the assertion that the generation of all insects is caused by the generative principle residing in the original and sentient vegetative souls, of which particles remain alive in the dead bodies of animals and plants, in a quiescent state, which is changed into activity by contact with surrounding heat and communicates new life to corrupt matter. There is still another class of wise persons who hold it to be true that generation proceeds from certain minute agglomerations of atoms, which contain the seed of all things. These persons say further that the seed was created by God at the beginning of the world and scattered in all directions for the fertilization of the elements, bestowing upon them, not a transitory, but a permanent fecundity as stable as the elements themselves; in this way, they say, are to be interpreted the words of the Sacred Book, "God created all things together." But that great philosopher of our time, the immortal William Harvey, also held that all living things are born from seed as from an egg, be it the seed of animals of the same species or elsewhere derived; thus he says, "Because this is common to all living creatures, viz: that they derive their origin either from semen or eggs, whether this semen have proceeded from others of the same kind, or have come by chance or something else. For what sometimes 
happens in art occasionally occurs in nature also; those things, namely, take place by chance or accident which otherwise are brought about by art, of this health (according to Aristotle) is an illustration. And the thing is not different as respects generation (in so far as it is from seed) in certain animals; their semina are either present by accident, or they proceed from an univocal agent of the same kind. For even in fortuitous semina there is an inherent motive principle of generation, which procreates from itself and of itself; and this is the same as that which is found in the semina of congenerative animals - a power, to wit, of forming a living creature." 1 But at first he had said that those invisible seeds, like atoms floating in the air, were scattered hither and thither by the winds; although he never explains whence or from whom they take origin; only it may be gathered from the above quoted words that he believes that those fortuitous seeds, flying in the air and carried by winds, proceed from an agent not univocal, to express myself in the language of the schools, but equivocal. Perhaps, however, he would have stated his opinion with greater clearness and precision if the notes which he had collected on this subject had not been dispersed during the tumult of civil war, to the deplorable loss of the republic of philosophy. Many persons would have difficulty in believing that Harvey could have hit upon the truth, in as much as they obstinately assert that it is impossible to indicate the efficient cause of the procreation of insects. The subtlest philosopher of past centuries, after vainly seeking it in our world, declared that the imme-

${ }_{1}^{1}$ Anatomical Exercises on the Generation of Animals (I651). Translated by Robert Willis. Works of William Harvey. London: Sydenham Society, 1847. p. 427. 
diate cause of the generation of insects was none other than the Omnipotent Hand of Him whose knowledge transcends all, that is, the great and good God, from whom all flying animals received their spirit directly, as Ennius thought, if we are to believe Varro, who wrote in the fourth book "De Lingua Latina" : "Ova parire solet genu' penneis condecoratum; Non animus, ut ait Ennius. Et post. Inde venit divinitu' pulleis insinuans se ipsa anima." Hereupon others add that it is no wonder Galen should confess so modestly in his book his inability to find this origin, and therefore prays all philosophers who may happen to fall in with it to let him know of it. But he, holding opinion contrary to the Platonists, was never able to believe that the Power and Wisdom which produces perfect animals, could be the same which stoops to form scorpions, flies, worms, and such like, called imperfect by the scholastics. What may be the truth among so many opinions or what comes nearest to it, I am unable to say, nor is it now in my power or intent to decide, but if it happens that I disclose my own belief on the subject, I do so with much hesitation, and fear, as I imagine that the lines sung by our divine poet sound in my ear:

"Aye to that truth which has the face of falsehood A man should close his lips as far as may be, Because without his fault it causes shame."

Although content to be corrected by any one wiser than myself, if I should make erroneous statements, I shall express my belief that the Earth, after having brought forth the first plants and animals at the beginning by order of the Supreme and Omnipotent Creator, has never since produced any kinds of plants or animals, 
either perfect or imperfect; and everything which we know in past or present times that she has produced, came solely from the true seeds of the plants and animals themselves, which thus, through means of their own, preserve their species. And, although it be a matter of daily observation that infinite numbers of worms are produced in dead bodies and decayed plants, I feel, I say, inclined to believe that these worms are all generated by insemination and that the putrefied matter in which they are found has no other office than that of serving as a place, or suitable nest, where animals deposit their eggs at the breeding season, and in which they also find nourishment; otherwise, I assert that nothing is ever generated therein. And, in order, Signor Carlo, to demonstrate to you the truth of what I say, I will describe to you some of those insects, which, being most common, are best known to us.

It being thus, as I have said, the dictum of ancients and moderns, and the popular belief, that the putrescence of a dead body, or the filth of any sort of decayed matter engenders worms; and being desirous of tracing the truth in the case, I made the following experiment:

At the beginning of June I ordered to be killed three snakes, the kind called eels of Esculapius. As soon as they were dead, I placed them in an open box to decay. Not long afterwards I saw that they were covered with worms of a conical shape and apparently without legs. These worms were intent on devouring the meat, increasing meanwhile in size, and from day to day $\mathrm{I}$ observed that they likewise increased in number; but, although of the same shape, they differed in size, having been born on different days. But all, little and big, after having consumed the meat, leaving only the bones intact, 
escaped from a small aperture in the closed box, and I was unable to discover their hiding place. Being curious, therefore, to know their fate, I again prepared three of the same snakes, which in three days were covered with small worms. These increased daily in number and size, remaining alike in form, though not in color. Of these, the largest were white outside, and the smallest ones, pink. When the meat was all consumed, the worms eagerly sought an exit, but I had closed every aperture. On the nineteenth day of the same month some of the worms ceased all movements, as if they were asleep, and appeared to shrink and gradually to assume a shape like an egg. On the twentieth day all the worms had assumed the egg shape, and had taken on a golden white color, turning to red, which in some darkened, becoming almost black. At this point the red, as well as the black ones, changed from soft to hard, resembling somewhat those chrysalides formed by caterpillars, silkworms, and similar insects. My curiosity being thus aroused, I noticed that there was some difference in shape between the red and the black eggs [pupæ], ${ }^{1}$ though it was clear that all were formed alike of many rings joined together; nevertheless, these rings were more sharply outlined, and more apparent in the black than in the red, which last were almost smooth and without a slight depression at one end, like that in a lemon picked from its stalk, which further distinguished the black egg-like balls. I placed these balls separately in glass vessels, well covered with paper, and at the end of eight days, every shell of the red balls was broken, and from each came forth a fly of gray

1 Throughout this work Redi uses the word "uova" where the context shows that pupa is meant. In this he followed Harvey, who called any embryonic mass an "egg." 
color, torpid and dull, misshapen as if half finished, with closed wings; but after a few minutes they commenced to unfold and to expand in exact proportion to the tiny body, which also in the meantime had acquired symmetry in all its parts. Then the whole creature, as if made anew, having lost its gray color, took on a most brilliant and vivid green; and the whole body had expanded and grown so that it seemed incredible that it could ever have been contained in the small shell. Though the red eggs [pupæ] brought forth green flies at the end of eight days, the black ones labored fourteen days to produce certain large black flies striped with white, having a hairy abdomen, of the kind that we see daily buzzing about butchers' stalls. These at birth were misshapen and inactive, with closed wings, like the green ones mentioned above. Not all the black eggs [pupr] hatched after fourteen days; on the contrary, a large part of them delayed until the twenty-first day, at which time there came out some curious flies, quite distinct from the other two broods in size and form, and never before described, to my knowledge, by any historian, for they are much smaller than the ordinary house-flies. They have two silvery wings, not longer than the body, which is entirely black. The lower abdomen is shiny, with an occasional hair, as shown by the microscope, and resembles in shape that of the winged ants. The two long horns, or antennæe (a term used by writers of natural history) protrude from the head; the first four legs do not differ from those of the ordinary fly, but the two posterior ones are much larger and longer than would appear to be suitable for such a small body; and they are scaly, like the legs of the locusta marina; they are of the same color, but brighter, so red, in fact, that they would put cinnabar 
to shame; being all covered with white spots, they resemble fine enamel work.

That different generations of flies issued from the same dead body was perplexing, and I sought further knowledge from experiment. To this end, having made ready six boxes without covers, I placed in the first, two of the snakes described above, in the second, a large pigeon, in the third two pounds of veal, in the fourth a large piece of horse-flesh, in the fifth, a capon, in the sixth, a sheep's heart; and all became wormy in little more than twenty-four hours. The worms, five or six days after birth, changed as usual to eggs [pupæ]. From those in the snakes there hatched, after two days, large flies, some blue and some purple. The eggs [pupæ] in the second box, some of which were red and others black, hatched out flies; green flies being produced from the red eggs [pupæ] after eight days, and after fourteen days the black eggs [pupæ] broke in the place where there was no depression, and there escaped from the shell the same number of black flies striped with white. Similar flies were seen issuing from all the other eggs [pupæ] in the boxes containing the veal, the capon, the horse-flesh, and the sheep's heart; but with this difference, that in the sheep's heart, blue and violet flies were produced, as well as the black flies striped with white.

In the meanwhile I had placed in a glass dish some skinned river frogs, and having left the dish open, I found the next day, on examination, that some small worms were occupied in devouring them, while some others swam about, at the bottom of the dish, in a watery matter that had run out of the frogs. The next day the worms had all increased in size and many others had appeared that also swam below and on top of the water, 
where they devoured the floating fragments of flesh; and after two days, having consumed all that was left of the frogs, they swam and sported about in the fetid liquid, now creeping up, all soft and slimy, on the side of the glass, now wriggling back to the water until at last on the following day, without my knowledge, they all disappeared, having reached the top of the dish.

At the same time I enclosed some fish, called Barbi, in a box full of holes, with a lid perforated in the same way. When I opened it after four hours, I found a large number of very minute maggots on the fish, and I saw a great many tiny eggs adhering in bunches to the joints and around all the holes in the interior of the box: some of these were white and others, yellow. I crushed them between my nails and the cracked shell emitted a kind of whitish liquid, thinner and less viscuous than the white of a fowl's egg.

Having rearranged the box as it was before, and having opened it, on the following day, I observed that all the eggs had hatched into the same number of maggots, and that the empty shells were still attached in the places where the hatching occurred; I also noted that the first maggots hatched had increased to double their size; but what surprised me most was that on the following day they had grown so large that every one of them weighed about seven grains, while only the day before there would have been twenty-four or thirty to a grain. All the later ones hatched were very small. The whole lot, almost in the twinkling of an eye, finished devouring the flesh of the fish, leaving all the bones so clean and white that they looked like skeletons polished by the hand of the most skilful anatomist.

All these maggots, having been placed where they 
could not escape in spite of all their endeavors, five or six days after birth turned as usual into as many eggs [pupæ], some of red and some of black color, and not of the same size; subsequently, at the proper time, different kinds of flies came out, green flies, big blue flies, black flies striped with white, and others resembling the marine locust and winged ants, which I have described. Besides these four kinds I also saw eight or ten common flies, such as daily hover and buzz about our dinner tables.

Having on the twentieth day noticed that among the larger eggs [pupæ], there were some still unhatched, I separated them from the others in a different vessel, and two days after there gradually came out of them some very small gnats, the number of which after two days had greatly exceeded the number of eggs [pupæ]. I opened the vessel and having broken five or six of the eggs [pupæ] I found them so packed with gnats that each shell held at least twenty-five or thirty, and at most forty.

I continued similar experiments with the raw and cooked flesh of the ox, the deer, the buffalo, the lion, the tiger, the dog, the lamb, the kid, the rabbit; and sometimes with the flesh of ducks, geese, hens, swallows, etc., and finally I experimented with different kinds of fish, such as sword-fish, tun, eel, sole, etc. In every case, one or other of the above-mentioned kinds of flies were hatched, and sometimes all were found in a single animal. Besides these, there were to be seen many broods of small black flies, some of which were so minute as to be scarcely visible, and almost always I saw that the decaying flesh and the fissures in the boxes where it lay were covered not alone with worms, but with the eggs from which, as I have said, the worms were hatched. These 
eggs made me think of those deposits dropped by flies on meats, that eventually become worms, a fact noted by the compilers of the dictionary of our Academy, and also well known to hunters and to butchers, who protect their meats in Summer from filth by covering them with white cloths. Hence great Homer, in the nineteenth book of the Iliad, has good reason to say that Achilles feared lest the flies would breed worms in the wounds of dead Patrocles, whilst he was preparing to take vengeance on Hector.

Having considered these things, I began to believe that all worms found in meat were derived directly from the droppings of flies, and not from the putrefaction of the meat, and I was still more confirmed in this belief by having observed that, before the meat grew wormy, flies had hovered over it, of the same kind as those that later bred in it. Belief would be vain without the confirmation of experiment, hence in the middle of July I put a snake, some fish, some eels of the Arno, and a slice of milk-fed veal in four large, wide-mouthed flasks; having well closed and sealed them, I then filled the same number of flasks in the same way, only leaving these open. It was not long before the meat and the fish, in these second vessels, became wormy and flies were seen entering and leaving at will; but in the closed flasks I did not see a worm, though many days had passed since the dead flesh had been put in them. Outside on the paper cover there was now and then a deposit, or a maggot that eagerly sought some crevice by which to enter and obtain nourishment. Meanwhile the different things placed in the flasks had become putrid and stinking; the fish, their bones excepted, had all been dissolved into a thick, turbid fluid, which on settling became clear, with 
a drop or so of liquid grease floating on the surface; but the snake kept its form intact, with the same color, as if it had been put in but yesterday; the eels, on the contrary, produced little liquid, though they had become very much swollen, and losing all shape, looked like a viscous mass of glue; the veal, after many weeks, became hard and dry.

Not content with these experiments, I tried many others at different seasons, using different vessels. In order to leave nothing undone, I even had pieces of meat put under ground, but though remaining buried for weeks, they never bred worms, as was always the case when flies had been allowed to light on the meat. One day a large number of worms, which had bred in some buffalomeat, were killed by my order; having placed part in a closed dish, and part in an open one, nothing appeared in the first dish, but in the second worms had hatched, which changing as usual into egg-shape balls [pupæ], finally became flies of the common kind. In the same experiment tried with dead flies, I never saw anything breed in the closed vessel.

Hence I might conjecture that Father Kircher, though a man worthy of esteem, was led into erroneous statements in the twelfth book of "The Subterranean World," where he describes the experiment of breeding flies in the dead bodies of the same. "The dead flies," says the good man, "should be besprinkled and soaked with honey-water, and then placed on a copper-plate exposed to the tepid heat of ashes; afterward very minute worms, only visible through the microscope, will appear, which little by little grow wings on the back and assume the shape of very small flies, that slowly attain perfect size." I believe, however, that the aforesaid honey-water only 
serves to attract the living flies to breed in the corpses of their comrades and to drop their eggs therein; and I hold that it is of little use to make the experiment in a copper vessel heated by warm ashes, for without these accessories the worms would have bred in the dead bodies. I also frankly confess my inability to understand how those small worms, described by Kircher, could change into small flies without at first, for the space of some days, being converted into egg-like balls [pupæ], nor how those small flies could hatch out so small and then grow larger, as all flies, gnats, mosquitoes and butterflies, as I have observed many times, on escaping from the chrysalis are of the same size that they keep through life. But, oh, how this single, ill-considered experiment of Kircher must have delighted and elated those persons who fondly imagined that they could re-create man from man's dead body by means of fermentation, or other similar or still more extraordinary processes! I am of the opinion that they might have used it as a base for their theories, and would have boastfully said:

"Thus do great sages openly proclaim That Phœnix dies and is reborn the same."

Whereupon these same boasters would perhaps have be stirred themselves about that incredible undertaking, which has been attempted more than once, as I have heard but have not believed. The absurd tale is not worth the trouble of confutation, for as Martial says:

"Turpe est difficiles habere nugas,

Et stultus labor est ineptiarum."

Even Father Kircher, in the eleventh book of the "Subterranean World," has nobly stood out against the folly 
of the charlatan, Paracelsus, who, impiously, would have us believe that there is a way to create manikins in the retorts of alchemists. I am still more scandalized at the assertions of others, who make these lies a foundation for conjecture concerning the greatest mystery of the Christian faith, namely, the resurrection of the body at the end of the world. The Greek, George Pisida, was one of those who exhorted people to believe in the Resurrection, giving the phœnix as an example of it; and the famous chemist, Sir Kenelm Digby, tried to prove the same by re-creating crabs out of their own salts, by chemical means. The holy mysteries of our Faith cannot be comprehended by human intelligence; unlike natural things, these are of the special workmanship of God, who is believed to be omnipotent, and therefore it is possible to believe blindly in all His works, for so they are best understood. In this sense a charming Italian poet wrote:

"Heaven's secrets he alone of men perceives, Who shuts his eyes and trustfully believes."

Leaving this long digression and returning to my argument, it is necessary to tell you that although I thought I had proved that the flesh of dead animals could not engender worms unless the semina of live ones were deposited therein, still, to remove all doubt, as the trial had been made with closed vessels into which the air could not penetrate or circulate, I wished to attempt a new experiment by putting meat and fish in a large vase closed only with a fine Naples veil, that allowed the air to enter. For further protection against flies, I placed the vessel in a frame covered with the same net. I never saw any worms in the meat, though many were to be 
seen moving about on the net-covered frame. These, attracted by the odor of the meat, succeeded at last in penetrating the fine meshes and would have entered the vase had I not speedily removed them. It was interesting, in the meanwhile, to notice the number of flies buzzing about which, every now and then, would light on the outside net and deposit worms there. I noted that some left six or seven at a time there, and others dropped them in the air before reaching the net. Perhaps these were of the same breed mentioned by Scaliger, in whose hand, by a lucky accident, a large fly deposited some small worms, whence he drew the conclusion that all flies bring forth live worms directly and not eggs. But what I have already said on the subject proves how much this learned man was in error. It is true that some kinds of flies bring forth live worms and some others eggs, as I have proved by experiment. Nor am I in the least degree convinced by the authoritative testimony of Father Honore Fabri of the venerable Company of Jesus, who asserts, in his book on the "Generation of Animals," that flies always drop eggs and never worms. It is possible (I neither affirm nor deny it) that flies sometimes drop eggs and at other times live worms, but perhaps they would habitually drop eggs if it were not for the heat of the season that matures the egg and hatches it in the body of the fly, which as a consequence brings forth live and active worms.

Johann Sperling, who is usually accurate in his statements, is also mistaken in writing in his "Zoölogy" that worms are not engendered by flies, but arise from the dung of the same, and in explanation adds with false premises: Ratio huius rei animis candidis obscura esse nequit; musca enim omnia liguriunt, vermiumque ma- 
teriam una cum cibo assumunt, assumptamque per alvum reddunt." Sperling failed to observe what may be daily seen by everyone, namely, that flies have their ovaries divided into two separate cells which contain the eggs that are sent down through a single and common canal from which they are ejected, and, indeed, in such large quantities as would appear incredible, certain green flies being so fertile that each one would have in its ovary as many as two hundred eggs. Hence Sperling erred in his belief that the maggots of flies are generated from the dung of the same. A friend of mine went equally wide in his conclusions, for having noticed that a fly, entangled in a web, dropped a worm whenever the spider bit it, he believed that the spider's bite had power to create worms in the bodies of flies. Hence as I have shown, no dead animal can breed worms.

How then can it be true that bees are born in the decayed flesh of bulls? Yet this statement has been made and believed. Varro relates that the Greeks called them Bovyóvas on that account. This is a sample of one of those ancient falsehoods of fabulous origin, which are subsequently confirmed as truth by other writers and always with some addition; for all do not describe the wonderful generation of bees in the same way. Columella declared that, not wishing to waste time, he would adhere to the opinion of Celsus, who conceded immortality to the bees, hence it was superfluous to seek for them in the entrails of a decayed bull. But Magone, quoted by Columella, teaches that the decayed viscera of the bull is their place of origin; to which Pliny adds, as necessary, a covering of dung. Antigonus Carystius, in his "Collection of Wonderful Histories," says that a whole bullock must be put under ground, allowing the horns 
to protrude; these, in due time being sawn off, out fly (says he) the bees. Ovid in the first book of the "Fasti" largely follows Antigonus:

"Qua, dixit, repares arte, requiris, apes?

Obrue mactati corpus tellure invenci;

Quod petis a nobis, obrutus ille dabit.

Iussa facit pastor, fervent examina putri

De bove: mille animas una necata dedit."

Varro, in the second book ["De Re Rustica"] does not state whether the bullock must be buried, or whether it might be left to rot above ground. Neither does Columella mention this detail, and Galen is silent concerning it in the fifth chapter of that book in which he inquires: "Is that which is contained in the uterus, an animal?" Virgil in his " Georgics," fourth book, seems to have been of the opinion that it is not necessary to bury the animal, but that it might be left in the open air in the woods.

"Quattuor eximos praestanti corpore tauros, Qui tibi nunc viridis depascunt summa Lycaei, Delige, et intacta totidem cervice invencas. Quattuor his aras alta ad delubra Dearum Constitue, et sacrum iugulis demitte cruorem, Corporaque ipsa boum frondoso desere luco.

And further:

"Post, ubi nona suos Aurora induxcrat ortus, Inferias Orphei mittit, lucumque revisit. Heic vero subitum, ac dictu mirabile, monstrum Adspiciunt: liquefacta boum per viscera toto Stridere apes utero, et ruptis effervere costis, Immensasque trahi nubes: iamque arbore summa Confluere, et lentis uvam demittere ramis." 
And yet he had stated in some verses preceding these, that a walled-in and covered place was requisite for this wonderful creation;

Exiguus primum, atque ipsos contractus ad usus Eligitur locus" . .

But Juba, king of Libya, according to Fiorentino, in the fifteenth book of the teachings of agriculture, insisted that the calf be placed in a wooden chest. Fiorentino does not seem to approve of this, on the contrary, holding the opinions of Democritus and Varro, and remembering the saying of Virgil, he affirms that this operation must proceed in a room especially built for the purpose, which he describes minutely, adding that common bees arise from the flesh of the bull, but that the queens are generated in the brain and in the spinal marrow; those originating in the brain being stronger, larger, and more beautiful. As for the number of days required for this work of creation, Varro differs from Virgil, assigning thirty-two instead of nine. Giovanni Rucellai is silent on this point, but he has otherwise fully described this remarkable process, in his charming, little poem on bees :

"In the green country, bordering on the Nile,

Whose waters rear the savage crocodile, Are people versed in many a skilful art.

A means they know, that I'll to thee impart,

Of adding to the number of their bees,

Should these be lessened by some dire disease,

Or Winter's frost, or any sudden harm

Come to the members of the busy swarm.

This is the way to recreate the race:

Choose first of all a very sunny place, Enclose it well, with walls encircling round, 
And with a tiled roof let the room be crowned; Four windows full ope then to the four winds, To let in light, life's maker, without blinds.

A fine young bull I then would have thee take, (Now hearken well, that there be no mistake)

He must be wearing newly his curved horn;

Scarce three years may have passed since he was born;

His noble vigor will his roar proclaim,

That echoing loud puts thunder, e'en, to shame.

Now, haply, hast thou heavy boughs and sound

To beat the calf till he fall on the ground;

Then, having shut him in the wallèd space,

Fresh poplar twigs and willow thou must place

Under the body, and on top be spread

Thyme and serpellium; cassia's for the head.

This must occur in the fair time of Spring,

When, to the Alps, on ever hastening wing,

The cranes return in a long, fleeting tribe

And the Greek delta in the air describe.

Now from the bullock's tender, yielding bones

A tepid humor gently oozing comes.

(Oh, Power of God, how measureless Thou art!)

Marvel of marvels! Now, from every part,

There come forth animals of simple kind,

Formless at first, dragging no legs behind,

Wingless, mere worms, that scarcely seem in motion,

What they may be, at first, one has no notion;

But soon the spirit does in them create

The members all, and limb to limb relate,

And many varied colors charm the eye,

As with spread wings the creatures humming fly;

Like misty rain, they seem, as on they come,

Lashed by the wind and sparkling in the sun;

Or like bright arrows from the bended bow

Of Turk or Parthian, they swiftly go."

Among the Greeks and the Latins there were many poets, who described this origin of bees, or alluded to it in various writings; Philetas of Cos, preceptor of Ptolo- 
mæus Philadelphus, Archelaus, the Athenian, cited by Varro, Philas of Tarsus (in the description of his famous antidote), Georgius Pisida, Nicander and, lastly, Ovid, who sings in the fifteenth of the "Metamorphoses":

"I quoque, delectos mactatos obrue tauros:

(Cognita res usu) de putri viscere passim

Florilegae nascuntur apes, quae more parentum

Rura colunt, operique favent, in spemque laborant."

Many prose writers also add confirmation to the theory, among whom may be mentioned Origen, Plutarch, the Hebrew Philo, etc. These ancients are followed by all the modern philologists and philosophers, who admit this fable to be true, and often on this foundation aspire to erect great structures. Even that sublime writer, that brilliant light of the modern schools, Pierre Gassendi, relates the tale as a true one, and having noticed that Virgil prescribes that the aforesaid operation should occur in the beginning of Spring, before the plants begin to flower:

"Hoc geritus, Zephyris primum impellentibus undas, Ante novis rubeant quam prata coloribus; ante Garrula quam tignis nidum suspendat hirundo:"

Gassendi says that the admonition is wisely made, for in that season the bullock [of the experiment] has fed on grasses bearing seeds, which later would have flowered; and he further adds that Virgil and Fiorentino correctly advise that the dead calf be placed on a layer of thyme and cassia, for these herbs contain seeds, most efficacious in the generation of bees; being very aromatic and pungent, they penetrate the rotten mass of the dead body, and make it turn into those same industrious insects. 
I repeat that many were, and still others are now, imbued with this idea, as for instance; Pietro Crescenzi, Ulysse Aldrovandi, Fortunio Liceto, Jerome Cardano, Thomas Moufet, John Johnston, Francis Grembs, Thomas Bartholin, Francesco Folli, inventor of the instrument which indicates the humidity and dryness of the air, and Philip James Sachs, a man of most inquiring mind, who in his learned book the "Gamberologia" makes every effort to uphold this thing as true; and though Johann Sperling, who is an accurate writer, had stated in his "Zoölogy" that during a great pestilence among the herds of Wittemburg, that fictitious generation of bees was not observed, nor seen in any way, nevertheless, Sachs, quoting in his own defense the "Idolatry," of Gerard Voss, answers that the coldness of the climate of that country was the cause of the failure to produce bees.

The artificial generation of bees was also a matter of belief with Father Athanasius Kircher, who even went further, stating in the twelfth book of the "Subterranean World" that worms resembling caterpillars arise in the dung of oxen, and putting out wings change into bees. I do not know whether that estimable author had ever carefully made this experiment; but when I made it, following Father Kircher's directions and leaving the dung in an exposed place, worms were hatched invariably in Spring, Summer and Fall, and from the worms arose flies and gnats, but not bees: if however the dung were kept in a tight place where no flies nor gnats could penetrate to lay their eggs, I observed no generation of any kind.

Returning to my subject, I affirm anew that numerous modern authors are convinced that bees originate in the 
flesh of bulls. The learned Father Honore Fabri, whose famous works will never be buried in the gloom of oblivion, reiterates this belief in his book on the "Generation of Animals." I could name many more if I were not summoned to answer the reproof of some persons who sharply remind me of the account given in the fourteenth chapter of the Book of Judges, where Samson having killed a lion, down in the vineyards of Timnath, on going afterwards to view the carcass, found in it a beautiful swarm of bees, that had already built their honey-combs therein. From this source comes also the statement of Thomas Moufet, in his work on insects, that some bees are born in the flesh of bulls, which are called ravpoyeves and others in the flesh of lions,

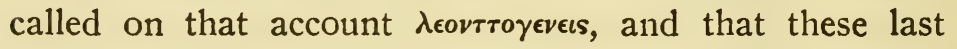
are the better race, being stronger and more courageous, for they inherit ferocity from their parent and do not fear if irritated to attack men and to kill animals of all kinds; hence Aristotle and Pliny bear witness that even horses have been slain by them. For this reason in the Holy Scriptures the strongest and most terrible enemies are often compared to bees. In Isaiah we read: "The Lord shall hiss for the bee, that is in the land of Assyria," which was thus interpreted by Chaldæus: "The Lord will give voice to the armies, that are as strong as bees, and will lead them to the borders of the land of Assyria." Rabbi Salomon, explaining this passage, says: "He will call the bees, that is, an army of strong men, who will inflict wounds like bees." This difficulty was considered by the erudite Samuel Bochart in his treatise on the animals of the Bible, where he wisely says that the story of finding bees in the lion's carcass is true enough, but that it is no reason for the conclusion that they were 
born there; the Sacred Text does not state it, on the contrary, one would rather assume that when Samson returned to look at the dead lion, it was no longer a carcass, but rather a skeleton without flesh. This same authority adds subsequently, that the lion might well indeed have become a mere dried skeleton, for when Samson returned it was "after some days," as the Hebrew text reads, which means "after a year." Bochart affirms that this manner of using days instead of a year is of frequent occurrence in the Holy Scriptures, and cites numerous passages which I omit for the sake of brevity.

If then Samson returned after a year's time to view the lion's body, it is most probable that nothing was left of it but a bare skeleton, inside of which bees may well have been at honey-making, for Herodotus mentions such a case; relating that the Anathusians having cut off the head of a certain man named Onesilo, and spiked it on the gate of Amatunta, on becoming dry it was inhabited by a swarm of bees. The same thing happened in the tomb of divine Hippocrates (if we may believe the account given in his life by Soranus). For my part, I remember often having heard stated by Cav. Albergati (a man of letters of much erudition), that he saw a large swarm, one day, hanging on the skull of a horse. At this point the question might arise whether some bees might have sought to eat the flesh of Samson's dead lion, and in eating it might have dropped eggs upon it, that later hatched into young bees, which proceeded to build their combs in the bony structure. To this question I would at once respond by saying that bees are very dainty animals, and of such nice and delicate taste, that they not only do not eat dead flesh, but they loathe it extremely. I have made 
the experiment, at different times and places, of putting pieces of meat near the apiaries, but the bees would never go near them. Still, if you do not credit my statement in the matter, Signor Carlo, at least you will believe what Aristotle says in chapter 40 of book I4 of the "History of Animals"; you will believe Varro, and Didymus, who copied him; and the Greek, Manuel Philes, who once flourished, having obtained all the material of his work from Elianus. Then there is the authority of Curopalata and of Balbo, emperors of Constantinople, and finally there is Pliny, who surely has weight with you; he wrote: "Omnes carne vescuntur, contra quam apes, quæ nullum corpus attingunt." But good Pliny, forgetting probably this statement, contradicts himself in chapter I4, book 2I, where he wrote: "Si cibus deesse censeatur apibus, uvas passas siccasve, ficosque tusas, ad fores earum posuisse conveniet. Item lanas tractas madentes passo, aut defruto, aut aqua mulsa. Gallinarum etiam crudas carnes."

On considering this manifest contradiction of Pliny's I thought it might be due to an error in the copy, but I removed all doubt by comparing this passage with many old written texts of the most celebrated libraries of Italy. In all I invariably found the same words as occur in the old Pliny printed in Rome in 1473 and in the Parma edition of 1480 . There is however this difference to be noted, i. e. all the printed works give: "Gallinarum etiam crudas carnes," while the MSS read: "gallinarum etiam nudas carnes." I leave the critics to decide which is the better reading, but I believe that Pliny wrote: " crudas carnes," having obtained his data from Columella, who, in chapter I4 of book 9 of his treatise, states that when food was lacking for the bees, many persons were 
wont to put unpicked dead birds in the apiaries. It is strange how writers itch to contradict each other; and this is perhaps why Pietro Crescenzi insists that hungry bees should not be fed with raw meat, but should be given roast chicken. I prefer to believe as Pliny does, that bees do not eat meat unless forced to do so by famine.

Bees are of different nature from hornets and wasps, for these greedily devour any kind of meat and putrefied flesh, that may be placed before them, as I have tried several times; not only do they eat meat, but they scrape and roll it into little balls, which they carry to their nests. These insects are so immoderately greedy that sometimes, when hungry, they even dare to attack living animals. Thomas Moufet, in his "Theatrum Insectarum," relates that in England a wasp was seen to pursue a swallow, and having stung it to death, gorged itself with the blood. Nor do they leave human flesh alone. Hence Cointo of Smyrna said that the Greeks led by Neoptolemus hurled themselves into the fray like wasps flying from their nests in search of human food. Likewise the sovereign poet, who in his divine works "showed the full power of the Tuscan tongue," took as his theme the sufferings of those doomed ones, who on the other side of Hell's gate were tormented with wasps:

"These miscreants who never were alive Were naked and were stung exceedingly By gad-flies and by hornets that were there.

These did their faces irrigate with blood, Which with their tears commingled at their feet By the disgusting worms was gathered up."

Wasps are gluttonous eaters of serpents, if we are to believe Pliny, and this food, says he, makes their sting 
more venomous; which statement is confirmed by Elianus in chapter I 5 book 9 of the "History of Animals," where he relates that wasps hasten to infect their sting with the toxin of the dead viper; from which human malice subsequently got the art of poisoning darts. Ulysses, as is recounted in the Odyssey, sailed to Ephyra to learn this art from a certain Ilus Mermerida, and Hercules, still earlier than Ulysses, as is told, made his arrows deadly by dipping them in the Hydra's blood. It is not credible that the stings of wasps and hornets are poisonous because these insects have fed indiscriminately on serpent's flesh, for that could be granted only in case they had dipped their stings in the fatal liquid hidden in the sheaths that cover the canines of the viper, as I stated in my "Observations of Vipers." If indeed wasps and hornets possessed this malicious natural disposition (as Ælianus asserts), I for one, would not be willing to believe it. In the remaining fragment of a book of Theophrastus, preserved in the Library of Fozio, on "Animals that are supposed to be malicious," he sagely holds that malice is never found in animals that are not endowed with speech. For if the newt, as people say, eats its cast off skin; if the sea calf, on being caught, vomits its rennet; if mares tear from their foals' heads the fabulous hippomane and devour it; if the deer (which is also a lie) hides his right horn underground when it falls off; if the lynx conceals his urine from the sight of man; and if the hedgehog, when caught by the hunter, spoils his skin by urinating on it; these acts, according to Theophrastus, are performed either through fear or for some other reason peculiar to the animals in question, but not because they maliciously desire to deprive man of those excrements, which the common people believe to be use- 
ful in certain diseases and also in the ridiculous compounds of witches. Imitating Theophrastus, I would still further say, that wasps and hornets buzz about the dead bodies of snakes, not in order to obtain poison for their stings, but to get nourishment; and to the same end do they persecute bees and flies. But still wasps do live on fruit and flowers, both fresh and dry, and they devour grapes, particularly of the Muscat variety, with incredible greediness, as Cointo, the Smyrnian, testifies and as may be daily verified by observation.

As I have said, it is false that bees are born in the decayed flesh of bulls; neither can one believe the tale that, in some parts of Russia, serpents are found, which feed on milk, and have a head shaped like a duck's, with a bill. These snakes are called "zmya," and are said to generate bees in their living bodies and then to throw them up little by little, at the rate of two swarms a year; these bees, being called "zmyoiocki," in the language of the country, retain much of their serpentine nature, and are armed with a poisonous sting, that is often fatal. This story is held to be a fact in those provinces, and many report that they have seen those peculiar snakes. A man, named Szizucha, in Paris, confirmed this account, as I have learned in a letter to me from the erudite Signor Menagio, who does not believe the tale, however. On the contrary, Signor Menagio considers that, assuming the existence of snakes that vomit bees, they must have been swallowed alive, at some time when the snakes were robbing honey from the hives. He says in the letter: "Il n'y a point d' apparence de croire, que ces abeilles s'engendrent dans le corps de cette sorte de serpens; et il est vraisemblable, que ces serpens les ayant avallées avec leur miel, car la plupart des serpens aiment les 
choses douces, ils les revomissent de suite, en estant piquez." Perhaps this phenomenon may have occurred once, and have been observed once, which was enough to give rise to a fable, that gained universal credence. Be this as it may, I shall add another fable to it, namely the origin of wasps and hornets from dead flesh, although by universal conformity of opinion it has been accepted as the truth.

Antigonus, Pliny, Plutarch, Nicander, Elianus, and Archelaus, as quoted by Varro, teach that wasps originate in the dead flesh of horses. Virgil admits it to be also the origin of hornets. Ovid mentions only hornets: "Pressus humo bellator equus crabronis origo est." Thomas Moufet reports that hornets are generated in the hard parts of horseflesh, and wasps in the tender parts. The Greek commentators of Nicander attribute the creative property to the horse's skin alone, adding as a necessary condition that the horse must have been bitten and torn by a wolf. But Servius, the grammarian, turned everything topsy-turvy by asserting that drones come from horses, hornets from mules, and wasps from asses. Olimpiodorus, Pliny, Cardano and Porta insist that ass-flesh gives birth to drones and beetles, but not to wasps. Oro in the twenty-third chapter, book second, of the "Hieroglyphics," speaks of wasps born in the flesh of the crocodile; and Antigonus in the twenty-third chapter of "Wonderful Histories" had occasion to say that, terrestrial scorpions, but not wasps are born spontaneously in the flesh of the crocodile. If such creation really occurs in the flesh of this reptile, I shall not perplex myself with dwelling on it, because I have not made any experiments in the case nor do I think that I shall be able to make any at present. I wish firmly to believe 
that, as I have found out the falsehood concerning the origin of those other insects supposed to arise from the flesh of mules, asses, and horses, I should find the story of the dead and decayed crocodile as the parent of wasps and scorpions to be equally fabulous. My experiments have proved just as false the accounts of Fortunio Liceto, Giovanni Batista Porta, Grevino, Moufet, and Nieremberg wherein is asserted that scorpions originate from buried crabs. These writers have accepted with too much credulity, and too naïvely Pliny's doctrine, which perhaps in turn was borrowed from Ovid's "Metamorphoses,"

"Concava littoreo demas si brachia cancro, Caetera supponas terrae, de parte sepulta Scorpius exhibit, caudaque minabitur unca."

But Pliny adds to this saying of Ovid's a condition of the kind held in veneration by the people, $i$. e. that this work should be done on precisely those days, during which the sun travels in the sign of Cancer. "Soli Cancri signum transeunte, et ipsorum, cum examinati sint, corpus transfigurari in scorpiones, narratur in siceo." This fable was not in the least credited by Thomas Bartholin, a man, by universal consent, numbered among the greatest and most famous physicians and anatomists of past and present ages, for in a letter written to the learned Philip James Sachs, he repeatedly affirms having observed that in Denmark, where there is an abundance of crabs, scorpions do not breed in their dead bodies. Sachs does not adhere however to the ideas of Bartholin; on the contrary, he believes in such generation, adding that the experiments made in Denmark prove nothing at all, as Northern countries are always entirely lacking 
in scorpions. Nevertheless, I feel inclined to believe (be it said with all due deference to such a worthy man of letters) that Sachs is perhaps mistaken, as are all the aforesaid modern authors in common with Ovid and Pliny. Not content with having scorpions come out of crabs, Pliny would have it that sweet basil, when pounded, and then covered with a stone, would also breed them, and his ideas were largely followed in later times by the Greek compiler of agricultural rules, who however does not allow the sweet basil to be buried under the stone, but avows that it must be masticated and then exposed to the sun. Porta follows this man's opinion, but Mattiuoli and Liceto hold to that of Pliny. In fact an infinite number of others attribute a like faculty to this aromatic herb. Wolfgang Oeffer, quoted in Sachs's "Cammaralogia," relates that, in our times, a certain apothecary of Vienna, more ingenious than his fellows, had found a way to breed the dangerous little creatures artificially. In the months of July or August, the sun being in Cancer, he pounded the sweet basil thoroughly and spread it over a red-hot tile to the depth of three fingers; this he covered immediately with a similar tile and cemented the joints with mud made of sand and horsedung; then he put the tiles in the cellar for a month, and afterwards on opening them, he found the scorpions ready born inside. Whereupon the good man made use of them for all purposes in which scorpions are medically efficacious.

An old opinion, though it be false, has great power over the minds of men. It is therefore not strange that Jacques Houllier, a physician of great repute, should believe, as is stated in Book first of his "Practice of Medi- 
cine," that a scorpion was born in the head of a certain man, an Italian, who had smelt sweet basil too freely.

"Twas perchance true, but not within belief

Of him who is the master of his mind."

But if Houllier had believed what Galen wrote about sweet basil in the second book of the "Properties of Foods" such an absurdity would not have escaped his pen. Michael Fehr, quoted by Sachs, was more accurate in his statements and more commendable, for having read in Galen that scorpions are not generated in sweet basil, he tried the experiment, and found that Galen was right and all the others wrong. Equally ignorant are those, who assert that not only sweet basil, but other things, such as watercress and rotten wood, produce these creatures. Fortunio Liceto relates that J. Marta, the Neapolitan, could breed scorpions from the soil of the earth by sprinkling it with onion-juice, and the wonderful secret mentioned by Avicenna was of similar nature. Aristotle more truly taught that scorpions are generated by the union of the males with the females, which do not lay eggs subsequently, as is the habit of many other insects, but bring forth the young scorpions alive and perfect according to their species.

I also made frequent experiments with scorpions. Having ordered a large quantity of them to be brought to me from the mountains of Pistoia, I selected some females, which are easily distinguished from the males by their large size, and on the twentieth of July I put them separately into glass vessels, leaving them without food. Some of them died before parturition but one of them, on August fifth, brought forth, not as according to Pliny 
and Aristotle only eleven, but as many as thirty-eight young scorpions, well-formed and of milk-white color, that changed to a rusty red, and on the sixth day of the same month another female, enclosed in another vessel, brought forth twenty-seven young of the same color as the first. The young behaved in the same manner, remaining attached to the back and the belly of the mother. They were alive up to the nineteenth day, but from that time they began to die, and only two were alive on the twenty-fourth day of August, after which they were also found dead. In the meanwhile, in order to ascertain how the insects were placed in the abdomen of the mother before birth, I cut open several females and found that there were never less than twenty-four nor more than forty young inside. These were all united in a row, and covered with an almost invisible membrane, through which the scorpions could be distinctly seen, each one being separated from the other by a very fine thread, a thickening, as it were, of the membrane itself. On this occasion I perceived that there was no truth in the reports of Aristotle and A. Caristio that the mothers are killed by the newborn young, nor, as Pliny relates, that the young are all killed by the mother, with the exception of one more clever than the rest, who runs up on his mother's back out of reach of her sting, and afterwards avenges his brothers' death by killing his parent. I took pains to verify Rodio's statement concerning a second litter following the first in a short time, but I did not succeed in observing anything further, nor, on opening the bellies of some pregnant females, did I see anything but the usual string of white scorpions. Still it is not impossible that the females had already brought forth 
many litters, and that I had always chanced upon the last.

I would not like to have you believe, Signor Carlo, that there is such a scarcity of scorpions in our Italy as Pliny says obtained in his time, writing in book eleven of his Natural History: "Sæpe Psylli, qui reliquarum venena terrarum invehentes, quæstus sui causa peregrinis malis implevere Italiam, hos quoque importare conati sunt. Sed vivere intra Siculi cœli regionem non potuere. Visuntur tamen aliquando in Italia, sed innocui;"- - for even to-day in the city of Florence alone, nearly four hundred pounds are consumed in the making of oil as an antidote to poison. I believe, however, that Pliny was right in affirming that the Italian scorpions are not poisonous, as I have often seen the peasants carry them about for sale in Florence, and handle them freely, thrusting their bare hands into the sacks and, though frequently stung, show no signs of poison. And yet all the Tuscan scorpions are of the kind that have six joints, or vertebræ, in the tail, which Avicenna considered more poisonous than others.

I do not wish to neglect telling you that, as the Italian scorpions which I have examined, have only six joints in the tail, the same is so with the scorpions of Egypt, as I noticed in the case of those which were sent in the year ${ }^{6} 6_{57}$ to my Lord, the Grand Duke. There is, however, no little difference between ours and the foreign ones: though both are of the same blackish color, the Egyptian scorpions are much larger and fuller than the others. Having placed in the scales an Egyptian scorpion, cleansed of its entrails, I found that it weighed twenty grains, while one from Italy on being weighed, 
scarcely reached five. The joints in the tail of the Egyptian scorpion are all of almost equal length and size, but in our kind the fifth vertebræ before the sting is always twice as long as the others. I have seen another species of scorpion somewhat different from the two kinds above mentioned. This was sent to me from the kingdom of Tunis by Dr. Pagni, a celebrated professor of medicine in the famous Pisan Academy, who is at present in Africa. Tunis produces these scorpions most abundantly: they are called "akrab" in the Berber tongue and are larger than the Egyptian kind. Once I weighed two live ones, each of which attained to the fifth part of an ounce, and they were lighter than usual owing to long deprivation from food. Their color is mostly of a faded yellow green, almost transparent like amber, except in the two claws, which are of a dirty color like chalcedony; the point of the sting is quite black. There are some white ones, but black ones are rare. The claws are made up of four joints. The legs are eight in number, and the two nearest the claws are shorter than the others; the second pair are longer than the first, and the third, longer than the second; the fourth are longer than all the others. The whole back is made up of nine joints and in the part between the two branches of the claws can be seen two very small, round eminences, which are black and shiny. Under the belly, which is composed of five joints, there are two dentated blades, that look exactly like saws, which, when the scorpion walks, he distends and agitates as if he wished to use them as wings. The tail has six vertebræ or joints, and the last of these is the sting, very large and hooked. The other five vertebræ at the upper end are hollowed out with dentated edges, and underneath they are round, convex and 
marked longitudinally with raised lines made of black dots. These Barbary scorpions hold the tail up and arched over the back not only when in a crouching posture but also when they walk. This seems to be a common trait of all the other kinds. Hence Tertullian writes in the "Scorpiacus":

"Arcuato impetu insurgens hamatile spiculum in summo, tormenti ratione, restringens;" and Ovid in Book fourth of the "Fasti": "Scorpius elatæ metuendus acumine caudæ."

There is a great dispute among writers whether the point of the sting has any aperture from which a drop of venomous liquid might issue when the scorpion wounds; and indeed the point is so polished and fine, that it is impossible for the eye to discover if it be really pierced.

Galen said that there is no hole or aperture of any kind. On the other hand, Pliny, Tertullian, St. Jerome, Aldrovandi, and many moderns have held that the scorpion not only pierces with the point of his needle, but also pours a liquid venom out of it into the wound thus caused. And Master Domenico Bandino of Arezzo, famous in his time as a writer of many ponderous works, some of which I have in manuscript in my library, asserted that the venom from the scorpion's needle is a thin white fluid. The poets say, on the contrary, that it is black: . . . "nigrumque gerens in acumine virus;" sang one of them. In order to be clear as to the truth, I selected from a great number of microscopes, belonging to His Serene Highness, the Prince of Tuscany, two of the finest, one of Roman and the other of English workmanship, with the aid of which $I$ in vain attempted to discover the opening in the spear end of the sting of the Tunisian, Egyptian, and Italian scorpions; 
and if I had given credence only to what was disclosed to me and my friends by these extremely fine instruments, I would have certainly declared that there was no aperture in the sting. But I was not satisfied with this evidence and therefore began to squeeze the scorpion's weapon; nor did this means at first succeed, as it was of a hard, crustaceous substance, which would not be compressed so as to allow the contents to squirt out. I irritated the scorpion and excited him to attack a steel blade with his sting, but no sign was left on it of any liquid. I was about to renounce further experiment and return to Galen's opinion, when suddenly there appeared on the point of the sting a very small, almost invisible drop of white water, which I have since observed many times, when the scorpion is irritated and makes attacks with his tail.

When I was making these experiments, one of the Tunisian scorpions was killed by one of his companions; I thereupon took the sting and punctured forthwith the breast of a pigeon with it four times; to the surprise of the onlookers there seemed to be no effect whatever from the punctures, and a slight doubt as to the venomosity of the Berber scorpions began to take hold of me. Dr. Pagni, mentioned above, writes to me from Tunis, that the Moors of the country constantly affirm that no year passes in which many men are not stung by scorpions, and that their poison is terrible and acts with incredible rapidity. Some time ago, says my friend, one Pietro da Santis, a merchant of Tunis, who was wounded by one of those little beasts in the left foot, suffered atrocious pains not only in the affected part, but along the whole thigh up to the shoulder. The man made great lamentation, and imagined that his whole left side was paralyzed. 
He was indeed lucky to get well after so much scarification of the wounds and repeated doses of teriac, with which also his whole foot was plastered, besides being treated with many other medicines.

Pagni also writes that the Berbers have the habit of carrying on their persons, or of affixing to the doors of their houses, a kind of bulletin made of a square piece of sheepskin on which are written certain Arabic names, together with seals and amulets. Such a superstitious preventive as those ridiculous bulletins coupled with another supposedly infallible remedy used by African physicians, i. e. giving water to drink, contained in fanciful cups of Unicorn horn, all this, I say, increased my doubt, but I did not dare to express it in view of such deeply rooted belief; still I resolved to persevere in the solution of the problem. Having prepared a live scorpion in such a way that he could not hurt me, and having thoroughly exasperated and irritated him, I forced him to sting the breast of a pigeon, several times, but, to the astonishment of many spectators, the bird showed no symptom of poisoning; the same can be said of a chicken and a puppy upon which I experimented.

Here I can foresee the onslaught of an army of philosophers, physicians, and writers of natural history, who, holding up their arms in the sign of the cross to conjure the evil, call out to me scornfully that the scorpion does kill not only small animals, but will not let even the largest and fiercest alone. He attacks the lion, and, according to Dr. Kemal Eddin Muhammed Ben Musa Eddemiri, he is not afraid of camel nor elephant. Others of these learned men tell me with an ironical smile, that it was no great wonder that the animals struck by my Tunisian scorpion did not die, since the scorpion had been 
shut in a vessel without food for four months, and hence had lost his venomous spite. Furthermore, as the experiment was made in the month of November, they recall to my mind, that Tertullian, who was born in Africa himself, in speaking of scorpions said: "Familiare periculi tempus Estas ; Austro et Africo sævitia verificat."

They also beg me to remember the saying of Macrobius, in the first book of the "Saturnalia," "Scorpius hyeme torpescit, et transacta hac, aculeum rursus erigit vi sua, nullum natura damnum ex hyberno tempore perpessa." My critics would also remind me of the statement of Leo Africanus, who relates that scorpions are so abundant and so annoying in the city of Pescara in Africa, that the inhabitants are obliged to leave during the Summer, returning only in November. This last objection is not only well founded, but it is also true, and proved by experiment, as I shall relate to you now.

The same scorpion, whose sting had no poisonous effect in November, continued to live throughout the Winter, being imprisoned in a glass vessel. In the month of January it had become so dull and drowsy that it looked as if about to die, but in February, though still without food, it began to revive and to take on strength; as it happened that I was then with the Court at Pisa, I decided on the twenty-third of February to try whether the scorpion had also renewed its poisonous and deadly powers. Monsieur Charles Maurel, a famous French surgeon, happened to come to see me on that morning, and in his presence I made the following experiment. Having plucked the feathers from the breast of a pigeon, I thrust the sting of the angry scorpion into its bare and bleeding flesh. Three times this was repeated; then 
the pigeon began to tremble and to move around in a circle with frequent gasps and palpitations. At four o'clock it fell to the ground, where it remained in convulsions until six o'clock, when it stretched out its legs, stiff and cold, as if the lower part were already dead; some tremors and movements of the head and wings still continued until eight o'clock, when the pigeon died; five hours having elapsed since it was wounded. As soon as it was dead, I received a visit from the erudite and celebrated Signor Nicholas Steno, who was anxious to observe the state of the entrails of the poisoned pigeon. At his advice I repeated the experiment, the second pigeon dying in half an hour. A third experiment followed, in which the wounded pigeon not only did not die, but seemed to feel no ill effects from the treatment. Thereupon I concluded to allow the scorpion to rest and recuperate its strength. In the meantime, I observed that the dead pigeons had not become swollen, nor did the wounds appear livid, neither was there any change in the state of the entrails. The blood, however, though remaining liquid had collected in large quantities in the ventricles of the heart, which seemed tumid and bloated, without having changed color in the least.

Having had frequent proof that animals killed by a snake's bite, or by tobacco, which is a terrible poison, can be eaten with impunity, I gave these pigeons to a poor man, who was overjoyed, and ate them with great gusto, and they agreed with him very well.

Having allowed the scorpion to rest until the following day, which was the twenty-fifth of February, at four o'clock I pierced the side of a deer with its sting, five times, and also punctured the buttocks, where the skin is less thick and is hairless. But the deer did not suffer 
from the prick. I observed that in these experiments, the scorpion of its own accord having twice stung the deer, did not succeed in penetrating the skin of the animal; this had to be done with my aid. Therefore I doubt whether the Barbary scorpions have the power to kill such thick skinned animals as lions, elephants, camels, etc., still I must rely on the good faith of the writers, who make these assertions, all the more as I must take into consideration that the scorpion, with which I made all these experiments, was out of his native land, and had been more than eight months without food, hence was weak and worn out.

In the case of the deer and the pigeon that were not killed, it is possible that the scorpion's supply of poison had been exhausted and he had not time to renew it. After some more experiments with different animals that resulted ineffectually, my scorpion died, so that I have not been able to determine whether a week's rest would have enabled him to renew his supply of poison. But I hope, nevertheless, to make all this clear with time, and also to explain other curious things about these strange little animals, so I have sent to Tunis and to Tripoli for a supply, and I am sending you a drawing of them in natural size.

To conclude my remarks on scorpions, I must add that the account of some of Pliny's followers, i. e., that dead scorpions come to life on being moistened with the juice of white hellebore, is an old wife's tale. As for Avicenna's assertion that a scorpion will fall dead if confronted with a crab to which a piece of sweet basil has been tied, it is likewise false, and having proved it so, I passed on to further experiments.

I killed half a pound of scorpions and exposed them 


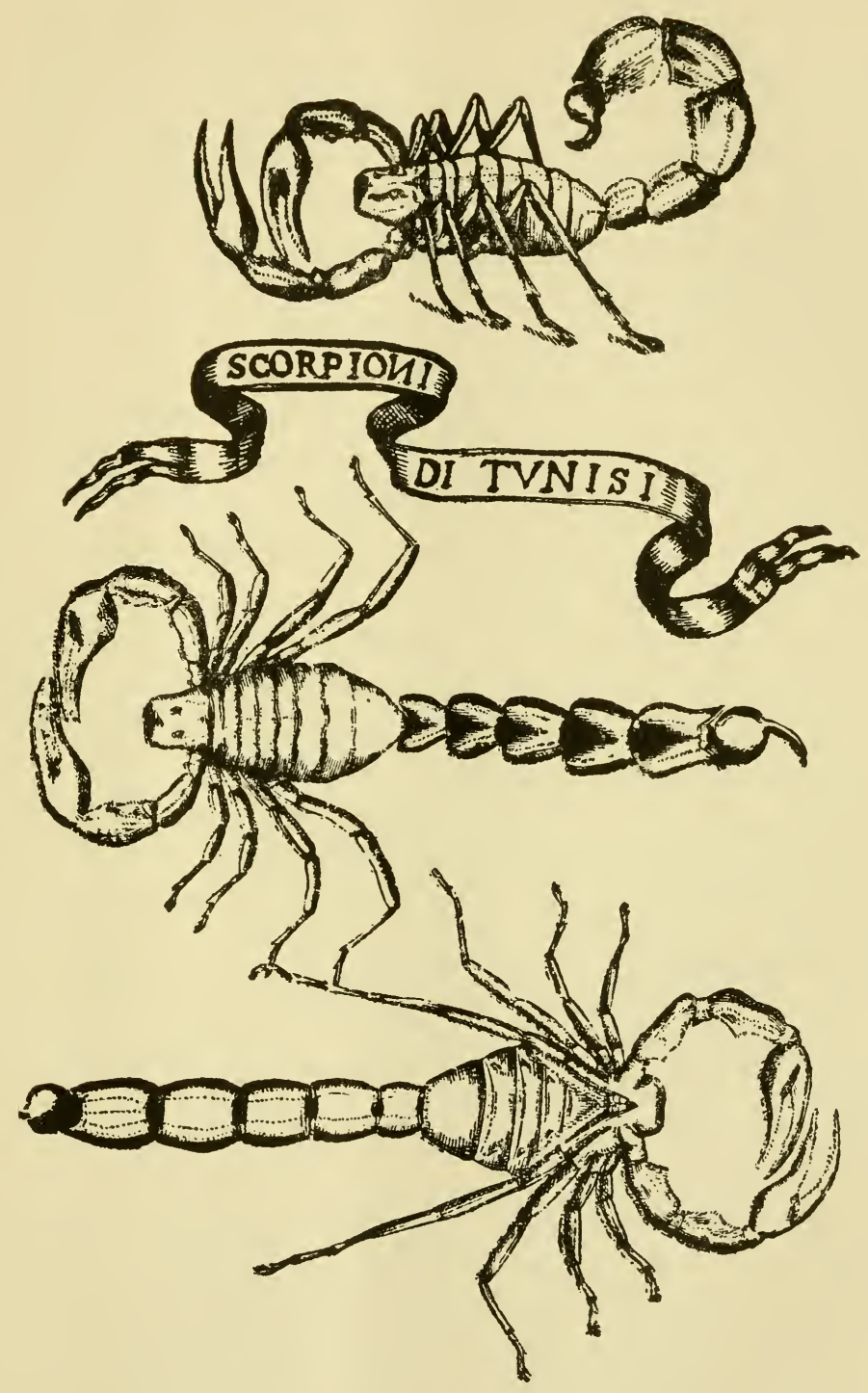


to the sun in an open glass vessel. In a short time they grew wormy, the worms being transformed as usual into black eggs [pupæ], from which, after an interval of fourteen days, an equal number of large, striped flies came out. As Father Kircher had stated that scorpions are reborn from dead scorpions themselves, if exposed to the sun and sprinkled with sweet basil and water, I risked a second and a third experiment, only to be disappointed and to await in vain the desired young scorpions, instead of which I always got flies; and when at the fourth attempt I saw neither worms, flies nor scorpions I was still further strengthened in my opinion that no animal of any kind is ever bred in dead flesh unless there be a previous egg-deposit.

This was a favorable opportunity for proving the statement of Batista Porta, that the toad is generated from a duck putrefying on a dung-heap. Three experiments with this material brought no result, hence I was convinced that Porta, otherwise a most interesting and profound writer, had been too credulous. And Avicenna was none the less so, for he would have it that women's hair, lain in a damp and sunny place, would turn into snakes. Now, I believe that snakes are only generated by means of coition, and all other kinds of serpentine creation, from rotten matter, or by other process mentioned by writers, are utterly false.

The story of Kiranis, that the tun-fish thrown up by the sea on the shore of Libya produces worms, that change to flies first, then to grasshoppers, and finally to quails, is not to be credited. No one in these days would be so ignorant or so stupid as not to laugh at such tales. Still, though I am, as you know, accounted the 
most incredulous man in the world with regard to natural phenomena, I desired to ascertain with my own eyes what the tun-fish might be capable of producing; but I had the usual result, and found only worms, which changed into flies, according to their species. I remember also that, wishing to see what effect oil had on the worms, as it is so pernicious to insects, I selected some of the largest worms born in the tun-fish and dipped some into vinegar, some into lemon-juice, and others into oil, sugar, salt and saltpetre. I found that all lived and followed their usual transformations excepting the worms covered with oil; the flies of these died on escaping from the shell, and some of them before leaving it. Hence I argued that the assertions of Galen, Lucian, A. Aphrodisius, U. Aldrovandi, and Sperling were correct: i. e., flies die on coming in contact with oil. Indeed, it was wonderful to see how quickly a fly died when I dropped oil on it. Aldrovandi and Sperling also add that flies killed in this manner return to life if left in the sun or sprinkled with hot ashes. Not caring to accept a mere assertion, I had the curiosity to verify it with my own eyes, but I never had the good luck to see a single fly return to life, though I repeated the experiment several times. Then, again, I had read Elianus, Pliny, and some moderns, who state that these same creatures, after having been drowned in water, revive on exposure to the mild heat of ashes. In order to prove this, I placed eight ordinary flies in a glass jar, well filled with iced water; after half an hour I found that one had gone to the bottom, and one of those floating seemed to be still alive; the other seven were apparently dead. I took all out of the water and placed them in the sun; scarce half a minute passed when two began 
to move and seemed to be about to fly away; of the other six, the one which had gone to the bottom, and three others that had floated on top, gave signs of life after three minutes by moving their legs and thrusting out their proboscides, but soon after they ceased all motion, and were really dead. A few days after, I made many experiments, keeping the flies in the water for longer or shorter periods; the water being sometimes iced and sometimes of ordinary temperature; sometimes I held the flies under the water; then again I would allow them to float. At last I ascertained that if the flies be really drowned they cannot be restored by the potency of the sun. Hence, I cannot see how it is possible to believe Columella, who reports that bees found lying dead under the beanstalks and which are kept all Winter in a dry place, return to life if, during the mild season of the equinox, they are exposed to the sun and powdered with fig-tree ash. I have not made this experiment, but I esteem it to be beyond belief.

I return to the flies hatched in the tun-fish: these, like all the others, on escaping from the shell began to excrete the natural abdominal impurities that are due, I believe, to the food consumed by them while they were still worms, in which state I noticed that they never excrete anything. The flies do not live more than four days after birth, when retained in the closed jars without food; but this is not an unusual rule in Nature.

What seems more strange is that spiders, born in closed jars from the eggs of the same, can live so many months without apparent food. On the fifth of July I shut up a female spider in a glass jar covered with paper, and I observed that on the twelfth she had spun herself a nest on the lower part of the paper, in the shape of half 
a nutshell, and in the cavity of this structure, called by Aristotle "seno orbiculato," there could be seen through the web-work round white eggs not larger than millet grains. From these eggs there hatched out on the last day of August a like number of tiny white spiders, which, immediately after birth, began to emit filaments. During the following two days all the eggs hatched, fifty in number, and in order to see how long the young spiders could live without food, I did not put anything eatable in the jar; hence, on the eighth of September, some of them died, and in the first week of October nearly all were dead, except three, which remained alive together with the mother, which in turn died on the thirtieth of December. The young ones, having noticeably increased in size, lived until the eighth of February. If you asked me why these three grew and became larger I should probably find a reason in their having obtained nourishment from the bodies of their dead brothers and mother by slightly sucking them; or if this were not so, the expansion of their bodies might make them appear to have really grown. However, I hold to the first opinion more than to the second, and it does not trouble me that people believe, and writers assert, that no animal will eat individuals of its own species, since I have found by many experiments that no fable was ever more fabulous than this one, and no one ever heard a more lying falsehood. I remember having forced a lion to eat the flesh of a lioness, nor did he do it from starvation, for on the same day he had eaten many pounds of mutton. The most ordinary hunter knows by experience that a dead boar left in the woods will be devoured by the live ones. Bears eat bear-meat and tigers, tiger-flesh, and I can assure you of a fact in proof of this. Meemet Bey, 
General of the Tunisian forces, sent a large number of strange animals from Africa to my Lord the Grand Duke. Among these there was a tigress with a newborn cub. On the way to Florence the good tigress, whether playfully or in anger I know not, tried her teeth on the cub and neatly broke off a paw and the attached shoulder, which she swallowed greedily, although there was other meat in the cage. Cats, on being castrated, sometimes devour their own testicles, and females of their kind eat up their newborn young. The pike, fierce in pursuit of prey, does not spare his fellows; indeed, these fish pursue each other most greedily; and it often happens that a pike of seven or eight pounds will attack one of three or four pounds. It is curious to watch the larger fish struggle to swallow the smaller one, which often sticks out of his mouth a hand's breadth, and for an hour or so the victor will swim about in the water in this way until the head of the swallowed fish enters the stomach of the other, and becomes gradually disintegrated and absorbed, making room for the rest of the body, which eventually slips in.

I enclosed other spiders, both male and female, in glass jars, but did not observe anything except their extraordinary capability of living long without food. I also noticed that one of the spiders, after a month's imprisonment, shed his entire skin, that looked exactly like another spider; another waited fifty days before shedding his. I am not the first to notice this peculiarity, which was alluded to by the learned Englishman, Thomas Moufet, in his celebrated work on insects, where he asserts that they not only shed their skin once a year, but even every month; this I would dare neither to affirm nor to deny, not having seen it. I thoroughly examined 
the different forms of glands and sacks in which the females lay and hatch their eggs as in a nest, and I admired the wonderful manner in which the threads were strongly attached even to smooth glass. But I will not dwell on this longer, nor on the labor and marvelous design of the web, as so many writers have described it admirably, and you yourself have written about it, in one of your erudite "Tuscan Vigils," that is entitled, "Nature, the Geometrician." Moufet asserts that there are often as many as three hundred eggs in those nests, and I have counted one hundred and sixty from one insect, which having deposited them all close together, wrapped them with her thread, and built around the ball a larger, white cocoon, in which it was left suspended. As the spider was weaving this covering I noticed that the thread did not come out of her mouth, but out of the end of the abdomen, and I thus verified the statements of Ælianus and Moufet. Pliny wrote that the thread was kept in the uterus: "Orditur telas, tantique operis materiæ uterus ipsius sufficit." But Moufet, taking into consideration that the males, which have no uterus, are able to spin as well as the females, does not approve of Pliny's opinion and taxes him with error. This is, however, wrong, because the word "uterus" used in this occasion by the great writer is adopted by the Latin authors not only in the sense of womb, but also in that of abdomen, as, according to Isidorous 2nd. Ist., "Uterum solæ mulieres habent, auctores tamen uterum pro utriusque sexus ventre ponunt." Therefore, Pliny did not err when he wrote: " orditur telas . . . etc.," but Aristotle erred greatly in contradicting wise Democritus, writing in the ninth book of his " History of Animals," that spiders do not extract their thread from the interior of the abdomen, but 
from the external part of the body in general, as though the material of the filaments were a kind of down, that covered them all over like bark. Aristotle was also wrong in instructing us that spiders bring forth live worms instead of eggs, for I have invariably found the contrary to be the case. And though others write that spiders are generated from flying seeds and from rotten filth, I cannot induce myself to credit them, especially as they only give the popular belief in the matter as proof, i. e., that spiders and their webs are to be found in new houses, before the plaster on the walls is dry; but mark that houses are not built in the twinkling of an eye, as Alcina and Atlantus built them, in ancient times; therefore it is natural that the spiders should have found the dust and refuse lime a good place for making their nests, and for hiding, and on coming out, they could climb up any high wall in a moment, and weave their webs there.

Another fabulous generation of spiders was given out as true by various authors, among whom are Pietro Andrea Mattiuoli, Castore Durante, and Fathers Kircher and Fabri. Mattiuoli affirms that oak-galls produce spiders as well as worms and flies; he also says that all galls, which have not been pierced, contain one of these three kinds of small animals, from the nature of which he deduces a terrible prognostic, saying that flies in the galls indicate war to occur in that year; if worms are found, the harvest will be poor; if spiders, there will be a pestilence. Father Fabri laughs at this prognostic; as for myself, I could easily cite many experiments to confute Mattiuoli, for in the space of three or four years I have opened more than twenty thousand galls, and have never found a single spider inside, but only flies and gnats and worms, 
according to the season in which I opened them; nor was there meanwhile war or famine in Tuscany. It is true, to be sure, that I sometimes found a little spider in a gall, but always in an open one, into which it had probably crept for hiding. This I deem at present sufficient answer to the assertions of Mattiuoli, but I reserve myself to speak later on of flies, gnats, and worms found in galls.

It is a little more difficult to answer those who desire to know how spiders succeed in taking the ends of their thread from one tree to another, since not having wings, they cannot fly. Moufet bears witness that spiders hop and throw themselves from one place to the other, and there is truth in this as regards any slight jump, for I remember that a gentleman of high rank told me that while he was traveling a spider spun his thread from one side of the coach door to the other, and the carriage having stopped, the spider threw himself suddenly on to the hat of an approaching horseman. Thus it is possible that they jump, and it may be also that wishing to stretch the thread from one tree to another, they first attach it to a branch, and then let themselves down by the thread to the level ground, thence they go by way of the surface to the foot of another tree, which they climb, dragging the thread after them and stretching it at a suitable height. A friend told me that one day he saw two spiders hanging from two trees not far apart, and he noticed that they jumped towards each other, and hooking themselves together, they securely tied their threads, and then proceeded to weave a large web. One might also suppose that, when a spider makes a web between two distant trees, it is by mere chance: that is, the spider, dangling from the tree by the thread may be carried by the wind to the nearest tree, and the thread not having 
been broken, is able to make his web. Father Blancano asserts that he has ascertained by experiment that the spider's thread is not simple and smooth, but is composed of many fine strands, so light that they float out in the air, in all directions, and catch in the branches of nearby trees, of which circumstance the spider quickly avails himself to make fast the first lines of the future web. This is possible, provided that the spider hangs down from a high tree. I have not had occasion to observe this, though I have frequently seen the spiders stretch their thread from one part of the highway to the other, and attach the ends to the tops of the stakes that support the vines, but since these stakes are not higher than three or four yards, and the road is at least eight or ten, wide, I cannot see how the spiders, from so low a height, could acquire sufficient force to give the principal thread the required length, so that the lateral filaments could reach the other side of the road. Everyone may think as he chooses about this; for my part I must return to my preceding argument and tell you that I collected a large quantity of spiders, and, having killed them, left them in a large, open dish, whither the flies eagerly swarmed to feed and to deposit their maggots, almost vengefully, so that the dead spiders soon became wormy, and the worms having hardened into eggs or chrysalides, from these flies hatched out, such as daily circle about our houses.

Leaving this subject for the present, as it seems to be sufficiently proven that flesh does not become wormy of itself, I deem it time to pass to the consideration of other things that have been supposed to produce worms; this opinion being held not only by the common people, but even by men of science. One of the most important 
things subject to invermination is cheese, and epicures boast that they know how to grow worms in it to tickle the palate, the recipe being one of those that I enumerated at the beginning of this letter. But the learned Gassendi suggests that flies and other winged animals having deposited or disseminated their seed on leaves and grass, these being subsequently eaten by cows, sheep, and goats, introduce into milk and cheese the seed capable of producing worms. Many people do not dislike this theory, nor do I deny it, but with all due deference to this illustrious philosopher, I cannot understand how those deposits could retain their special powers after having passed through the complicated process of mastication in the mouth, and of digestion in the stomach, of the animals that have swallowed them. What seed could hold out, unchanged, against the double action of the pancreatic acid and of the bile in the intestines, whence in the passage to the udder it is further acted upon? For if Gassendi's idea were correct, one might expect to obtain mullet and eels from cheese made of woman's milk, if the woman had eaten the eggs of the same; or indeed, cockerels and pullets, if she had swallowed hen's eggs. Many women suck them raw, as they come from the nest, though even supposing them to have been eaten cooked, by the woman in question, it would have made no difference, for, according to Gassendi, cooking does not affect the generative principle, as witness the worms that appear in curds, etc. It would seem more probable that the invermination of milk, cheese, and curds is due to the same cause that I have given above, in the case of meats and fish, that is to say, flies deposit eggs in them from which worms are hatched, which change into flies. This will appear evident to anyone who considers the mat- 
ter in the light of reason, for neither milk nor cheese ever grow wormy, if they are kept in a place secure from flies; this is sufficiently proven by the experiments already made, and the contrary happens in case of exposure to flies. As I recall certain things that I have observed in connection with the breeding of worms, I shall relate them to you, leaving out such as appear superfluous and tiresome.

I had placed half of a fresh cheese, the best to be found in June, in a large, uncovered, glass dish; after a few days several worms appeared in it, which upon examination seemed of two kinds; the larger were of the ordinary sort produced on meat, and the smaller were of the same shape, but had this peculiarity: they were more spry and agile than the others; they moved about with great ease, and would take their tails in their mouths, thus forming a circle, or would skip here and there, sometimes escaping from the vase. Three or four days after birth all the worms ceased from motion, as usual, and shrunk into eggs [pupæ], differing only in size; these I separated and placed in different vessels. After eight days ordinary flies came out of the larger balls [pupæ], and from the smaller there emerged, after twelve days, small flies resembling winged ants, which immediately after birth skipped about with incredible sprightliness and vivacity so that they seemed to be the embodiment of perpetual motion. Then, every male pairing with a female, performed those acts from which propagation might be expected, but owing to lack of nourishment they died after a short time. While making this experiment I fortunately found a cheese that had just begun to grow wormy, and after separating: the good part from the bad I enclosed both in separate 
dishes; from the good part worms were hatched, and from those worms already in the bad part there appeared numerous little black flies, like those mentioned above, but not a single common fly. I know that it is hard to believe that milk products do not breed worms spontaneously, for worms are often found in the heart of our most delicate Lucca cheeses. I could suggest that the eggs producing these worms were laid by flies in the milk at milking time, when the milk is left in the pails to gather, and is surrounded by swarms of flies. Hence the Greek poet, "to whom the muses gave suck more freely than to others," in the sixteenth book of the Iliad, verse $64 \mathrm{I}$, compares the Greeks and Trojans, who were fighting over the body of Sarpedon, to the flies that buzz over the milk-buckets in the Spring. This reason, though not without value, does not satisfy me, nevertheless, and I think it probable that the eggs were laid by flies in the cracks of the ripening cheese, and the young maggot, seeking the tenderest food, worked his way to the heart of the cheese; escaping thence at the determined time, he seeks a place where he can fix himself for the few days of transformation, whence he issues in the flying stage, according to the type of parent.

Feeling that I have spoken sufficiently about this matter, perhaps even with too great prolixity and tediousness, I shall pass on to tell you about those worms popularly and erroneously believed to arise spontaneously in vegetables and decayed fruits, in wood and in trees.

Know, then, that as it is true that meats, fish and milk products kept in a protected place do not breed worms, it is likewise true that fruits and vegetables, raw and cooked, secured in the same way, do not grow wormy; 
or in the contrary case, left in an exposed place, will produce various insects of different species, according to the animals that have made deposits therein. But I have noticed that a preference is sometimes shown for a special vegetable or fruit in selecting the nesting-place. I had seen many flies light on a melon that showed later small worms, which, after four days, changed into eggs [pupæ] from which in four more days there were born an equal number of gnats.

In some pieces of mashed melon on which gnats and common flies had been feeding, together with another kind of fly, small, black, and with long antennæ, there were dropped worms of different size, that in due time were changed into eggs [pupæ] of different size. Common flies came out of the larger ones in eight days; from some of the smaller ones gnats appeared after four days, and from those of medium size were hatched the largest flies of all. I had the same result in experimenting with cucumbers, strawberries, pears, apples, plums, lemons, figs and peaches.

In my experiments with raw and cooked pumpkin, the common fly was the only insect that hatched. But I must not neglect to mention that all worms hatched in a certain preparation of boiled pumpkin and egg, which had reached the state of decomposition, acted in an extraordinary manner, rolling themselves about in the pap that stuck fast and covered them up, so that they resembled little clods of earth from which finally the flies were hatched. Now, anyone who did not know that an egg was concealed in each ball would have reasonably judged that those flies were hatched directly from the little balls. From some such illusion, I believe, originated the error of Pliny and others, who relate that infinite 
kinds of animals are bred in the soil, in mud, in swamps, and in the bed of rivers. Thus Ovid, in the first book of the "Metamorphoses" writes:

"Sic ubi deseruit madidos septemfluus agros

Nilus, et antiqua sua flumina reddidit alveo,

Aetherioque recens exarsit sidere limus:

Plurima cultores versis animalia glebis

Inveniunt, et in his quaedam modo coepta sub ipsum

Nascendi spatium: quaedam imperfecta, suisque

Trunca vident numeris: et eodem in corpore saepe

Altera pars vivit; rudis est pars altera tellus.

Quippe ubi temperium sumpsere humorque, calorque:

Concipiunt; et ab his oriuntur cuncta duobus.

Cumque sit ignis aquae pugnax; vapor humidus omnes

Res creat, et discors concordia foetibus apta est."

This opinion was seconded by Plutarch, by Macrobius in the "Saturnalia," by Pliny, and finally an innumerable host of ancients, who were followed like sheep by an infinite number of modern writers. Thus it is that I am sometimes astonished in considering how these authors conceived Nature to be so careless a generatrix, now creating animals of flesh and bone, and then making others of pure clay. But we have Ælianus's word for it that he saw animals made in this manner on a journey from Naples to Pozzuoli; and Ovid, not content in the above-quoted verses with having driven into our heads his story of seeing animals in mud, without legs or joints, clenches the fact again in book fifteen:

"Semina limus habet virides generantia ranas:

Et generat truncas pedibus; mox apta natando

Crura dat, utque eadem sint longis saltibus apta."

But what causes me most amusement is the statement of Pliny that these same frogs, after a short life of six 
months, return suddenly to dust and mud, whence they again, on the approach of Spring, resuscitate to a new life.

This thought of Pliny's has been approved by many grave philosophers of our century, and particularly by Father Fabri, who in his justly celebrated book on the generation of animals, at propositions seventy-five and seventy-six, admits that frogs are regenerated from the decayed bodies of other frogs. At present I am not inclined to believe this, not having seen anything of the kind; but I am always ready to change my mind, especially if Pliny's frogs had happened to have been torn and bitten by some hydra or other beast of serpentine nature such as our divine poet put in hell, and whose bite utterly consumed one of the damned, the ashes of whom, however, had power to gather together and reform the victim. But these are all fables. Those animals that apparently were made of earth, had they been closely examined, it would have been evident that they were merely covered with mud; and though living things do arise in swamps and mudholes, it is because eggs have first been laid in those places, just as Aristotle and Pliny tell of locusts and mantis.

Land-turtles also lay eggs and put them under ground; and those that live in fresh or salt water lay eggs on the shore and cover them with sand, where they are acted upon by the sun's heat, and hatch; whence an inexperienced person might conclude that the little turtles were born directly from the earth, from which they are seen issuing. Something of this sort explains Father Athanasius Kircher's curious experiment. This learned man of letters, who is very ingenious in his speculations, says as follows: "At the beginning of March, the frogs 
deposit their eggs freely in the ditches where they live; this humus, on becoming dry, turns to dust with its contents. Hence, if you wish to create a new generation of frogs, you will proceed in this manner: take the fertile dust of the swamp or ditch where the frogs have made nests, moisten it with rain-water and put it in an earthen dish in a place exposed to the warm rays of the summer sun; see that it does not get dry, and keep it well sprinkled with the aforesaid rain-water, and you will notice first of all certain little balls, that swell up and emit a large number of little white frogs, which have only their forefeet and a tail, that afterwards divides into two parts, forming the hind feet; these little creatures become perfectly formed frogs." This experiment ought by all probabilities to succeed, but I have never had the honor of being able to confirm it, owing possibly to some lack of attention on my part, or to some unknown obstacle, which, however, may be found in my having carried out Father Kircher's rule to the letter, using, namely, the dried mud of the ditches, to obtain which I must perforce wait until summer-time, when all the frogs were already hatched. I have, however, observed that frogs and toads first appear after birth, in the swamps and ditches, shaped like a fish, not with forelegs alone, but without any legs, and having a long, flat and sharp-edged tail; and in this shape they swim about for days, feeding and growing; then they thrust out the two forelegs, and after several days, the two hindlegs, from a skin that covers the whole body; some time having elapsed, they cast their tail, which does not divide into two parts to form the legs, as Pliny and others believed. This fact may be proven by anyone who will take the trouble to examine some newborn frogs by means 
of a dissecting knife, when it will be seen that the hindlegs and the tail are separate members of the body; and if the frog be kept in an aquarium it will be seen to swim about for several days equipped with its tail as well as its four legs.

What shall I say in regard to those frogs or toads which people believe are rained down from the clouds in summer, or are created in the dust by the raindrops? I have treated the subject at length in my "Observations on Vipers," in which I said that those small frogs appearing during a shower have already been hatched several days before, and have meanwhile hidden during the dry weather among bushes, behind stones, or in holes, and being of the same color as the soil, it is not easy to distinguish them from the ground on which they squat. The fact, also, that their stomachs are full of food and their intestines full of excrement, at the moment when they are supposed to have been born, appears to me a clear contradiction of the truth of this account, which dates from the II 4 th Olympiad, and was recited in the peripatetic school of Theophrastus Eresius, the successor of Aristotle. A fragment of Theophrastus's book about animals which make sudden appearances may be found in the Library of Fozio, to which I refer you, as I wish to speak of something else.

As I asserted above my disbelief in the statement that animals had been found, in the fields inundated by the Nile, that were partly composed of pure earth, so it is equally difficult for me to believe that trees and plants may produce creatures of similar nature, found to be half alive and half of inanimate wood, as if incomplete; and though the aforesaid Father Athanasius Kircher, in the second volume of "The Subterranean World," writes 
that he has seen such things, and has even shown them to others, as occurring on branches of viburnum, brionia and on twigs of the plant called horse-tail in Tuscany; but I do not doubt that there was some ocular illusion in the matter, and I do not hesitate to freely record my doubt, knowing Father Kircher to be a sincere lover of truth, who has spared himself neither mental nor bodily fatigue in its eager pursuit. Thus I, having the same object, write my opinion freely, being mindful of the poet's words :

"If to the truth I prove a timid friend, I fear lest I at last my days may end Among those men who will on History's page Be censured, for they were behind their age."

And this fear, together with my love of truth, impels me to confess frankly that even I, in days gone by, when blinded by inexperience, have believed in things that I am ashamed to remember now. Really, I must have seen double when I wrote in my "Observations on Vipers" that the heart of the snake has two auricles, and two cavities or ventricles, because a viper's heart has, in fact, only a single auricle and a single cavity; though it is true that the single auricle, when swelled, divides itself into two trunks, as it were, and has internally a fine membrane that almost divides it into two cells; and it was in exploring these two divisions with the probe that I hit upon the error of the two ventricles, one of which is really there, but the other was carelessly made with the probe.

I had become so interested in the curious animals, part animate and part woody, described by Father Kircher, and was so desirous of finding some, that I 


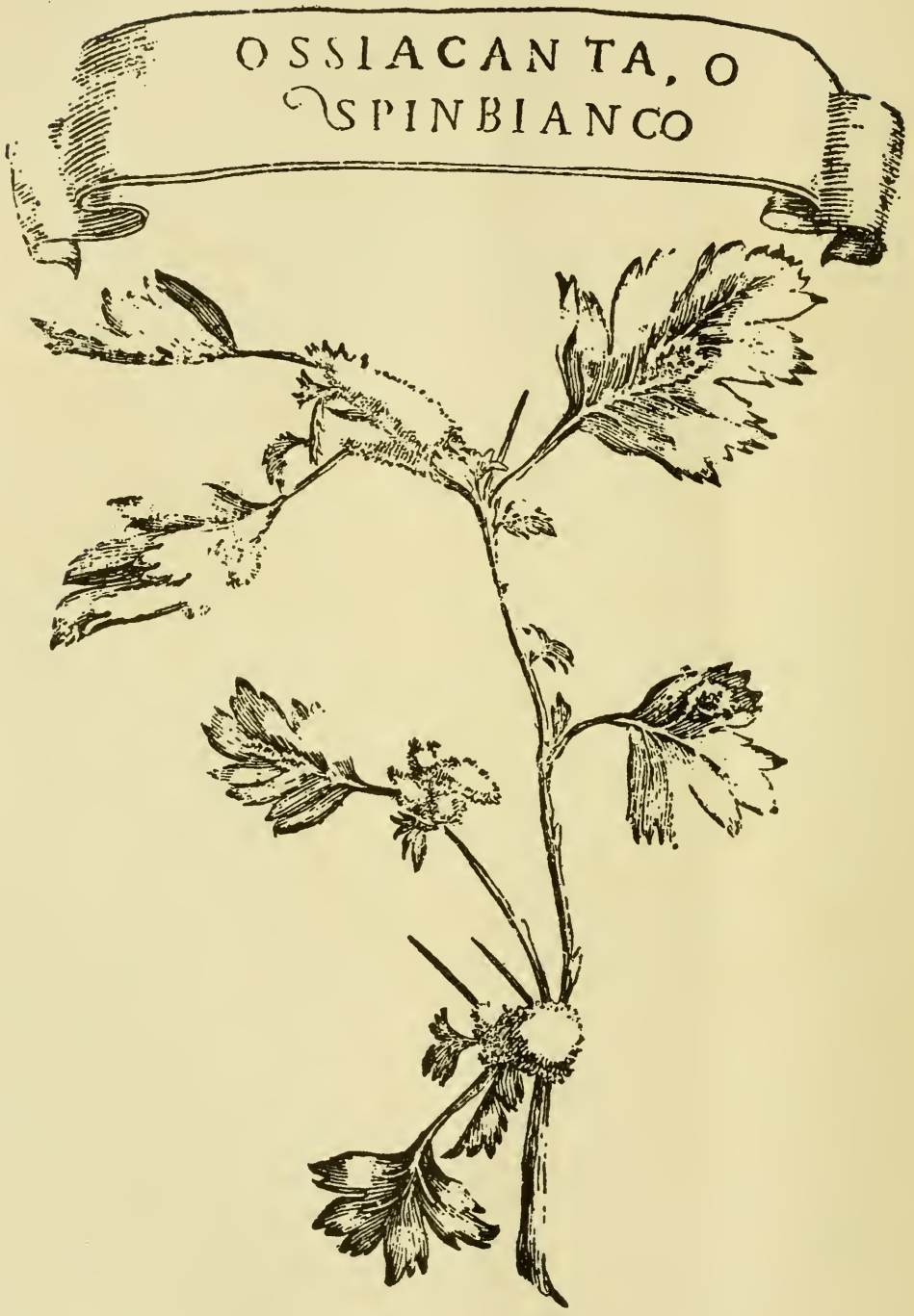




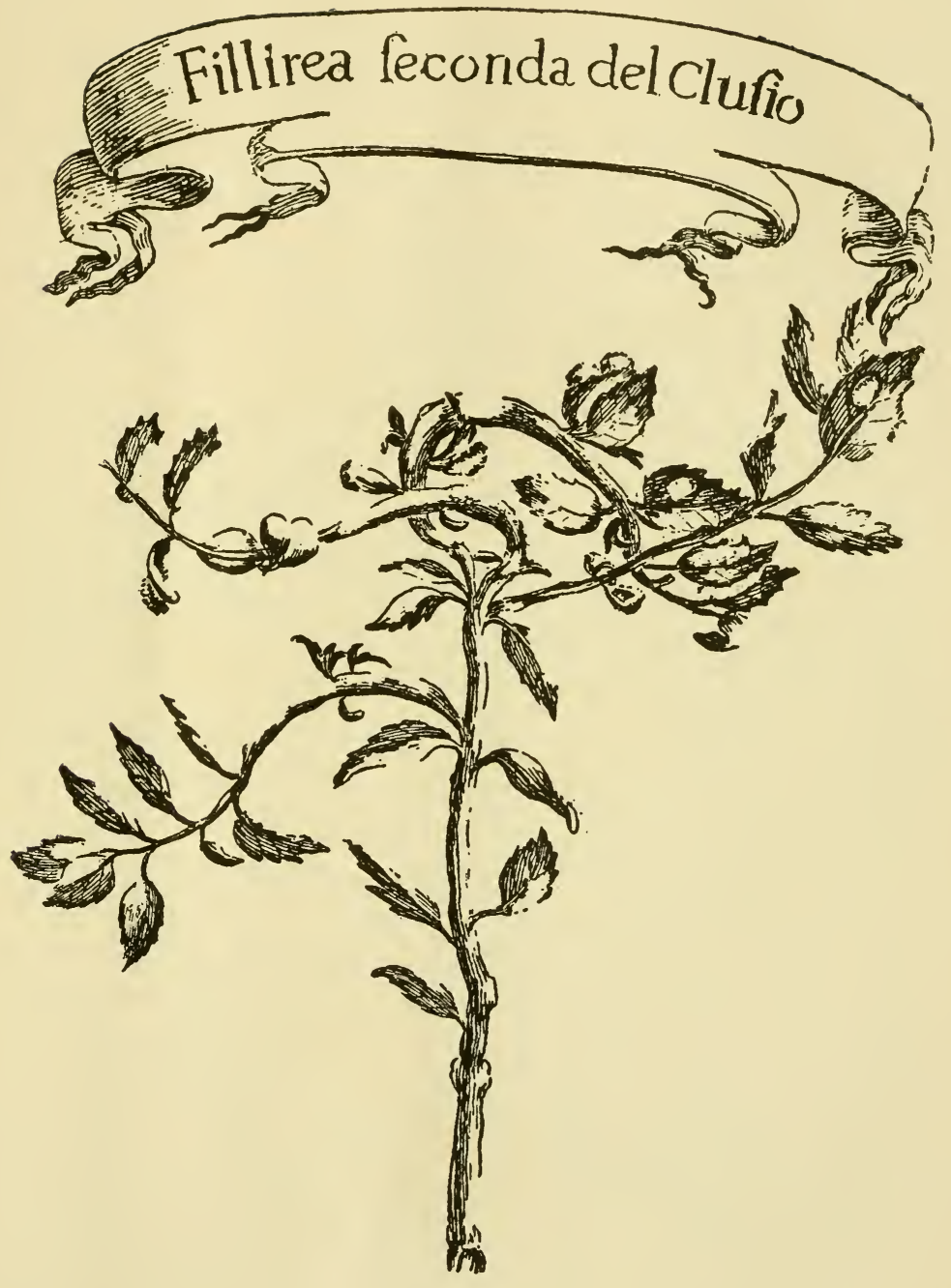




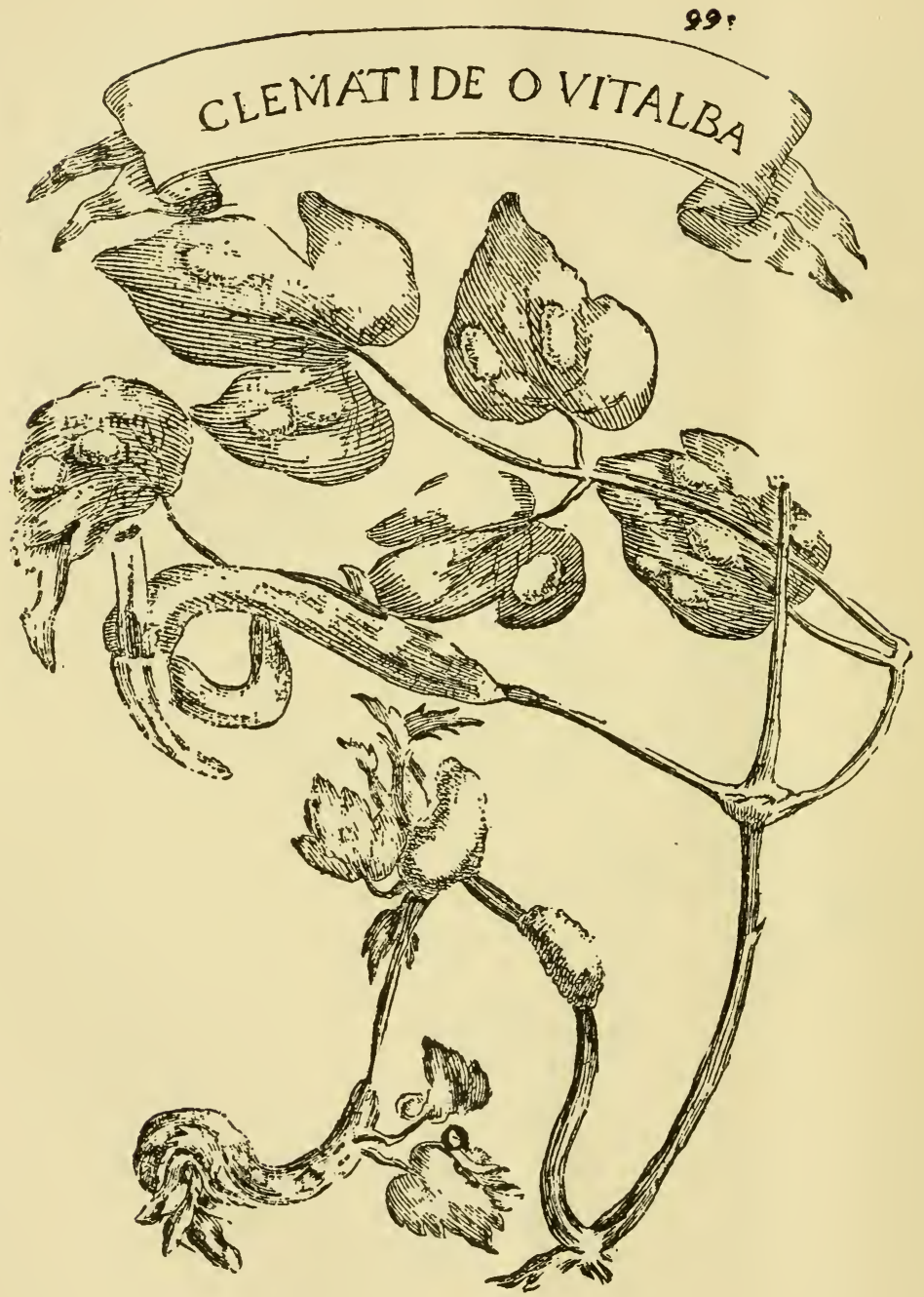


made every effort in the search. Whereupon, on the thirtieth of May, having received some branches of whitethorn, which presented various deformed and knotty growths, I hoped to witness the desired transformation. I also obtained and closely observed similar growths on branches of Fillerea seconda, and others on sprigs of clematis, called vitalba in Tuscany, but I at last recognized the fact that these growths are a natural freak of the plants that occurs every year and does not produce worms. You can examine the accompanying plates, which I gladly send, especially as I believe that the freak or sport has not been noticed before by any writer.

I hope it will not tire you if I describe another little animal mentioned by Father Kircher, supposed to breed in rotten cane and straw. While with the Court this year at Artiminio, for the hunt, I saw on the broom in the woods an infinite number of queer little creatures, called by the peasants "cavallucci" [mantis]. I found these to be of two sorts; some were green with two white parallel lines running the length of the body, and the others were rusty red, like the stalks of broom; both kinds have little horns, with many articulations. They move slowly and solemnly. They have six legs, and every leg has three joints; the two forelegs arise just under the part to which the head is attached. The head is very small, less than a grain of wheat; the eyes are hard and upturned, and smaller than a poppy-seed, and are red. All the space between the last pair of legs and the tip of the tail is composed and marked by ten rings, incisions, or knots; and from the last of these knots, two very fine spurs protruded. The whole body is not longer than the width of five fingers, and is of the same size from head to tail; though some are larger in the 
abdomen, these are always females, and are large-bellied in proportion to the number of eggs they carry. The males, as well as the females, cast their skin whole, like snakes, spiders, and other insects, the skin being nothing more than a fine white tunic shaped like the body. When these little animals were brought to me I was so fortunate as to have with me Signor Nicholas Steno, of Denmark, a famous anatomist, as you know, and a man of gracious and amiable manners, who is being royally entertained at this Court by His Highness, the Grand Duke. It occurred to both of us to examine the entrails and the internal structure of these little creatures as far as their minuteness would allow. We saw that a canal, starting from the mouth and extending through the body to an aperture near the last joint of the tail, performs the functions of the œsophagus, stomach, and intestine; and around this little canal we found a confused mass of many and divers filaments that are, perhaps, veins and arteries. From the middle of the body to the end of the tail we saw a large number of eggs, bound together and enclosed in a sac hardly discernible on account of its thinness. These eggs were not larger than millet grains, and some were soft and tender; others were hard. The soft ones seemed yellowish and almost transparent; but the hard ones, though yellow inside, had a black shell; and taking them all together, black and yellow, in a single animal we counted up to seventy. While we were thus engaged we observed that notwithstanding the fact that we had torn the entrails out of some of these animals, they continued to live and to move in the same way as do disembowelled reptiles. Whereupon we cut off the heads of others, and the head lived for a short time without the body; but the headless body was extremely lively 
and groped about as if in full possession of its parts. Then, just for a joke, and to amuse the company at the Villa, we resolved to graft the head on the body again, which we succeeded in doing with the same ease as the enchanter, Orrilo, who put his dismembered body together, and of whom the epic poet of Ferrara thus sings:

"Oft times asunder his stout limbs they hewed, Nor could they thus succeed the man to kill, For hand or leg cut off, with ready skill, The bold enchanter, in its place, renewed. His head does Grifon cleave, now, to the chin, Now Aquilante's sword sinks to his chest; He laughs at this blow as at all the rest. In helpless rage they curse this Satan's kin. Hast seen the slippery silver break and fall, Called mercury by some old alchemist? How fast it runs in many a shining ball, Then joins in one, and not a drop is miss'd! Thus Orrilo does seek his severed head, Nor till he finds it, leaves off stumbling round;

Then seizing it by the long locks of red, Or by the nose, straight on his neck 'tis bound. Now Grifon hurls him, with a mighty hand, Into the stream, but this does nought avail; Swimming below, without an ache or ail, Orrilo crosses to the other strand."

Thus our little animals, with their grafted heads, lived, not only all that day, but for five continuous days, to the great surprise of all who were not in the secret. And in that state they not only dropped their excrement, but even laid their eggs. Hence, an overhasty writer would have had many eye-witnesses to vouch for the truth of this experiment, but in asserting the restoration of the heads as genuine, he would be writing sheer nonsense, for the heads adhered to the trunks by means of a green, 


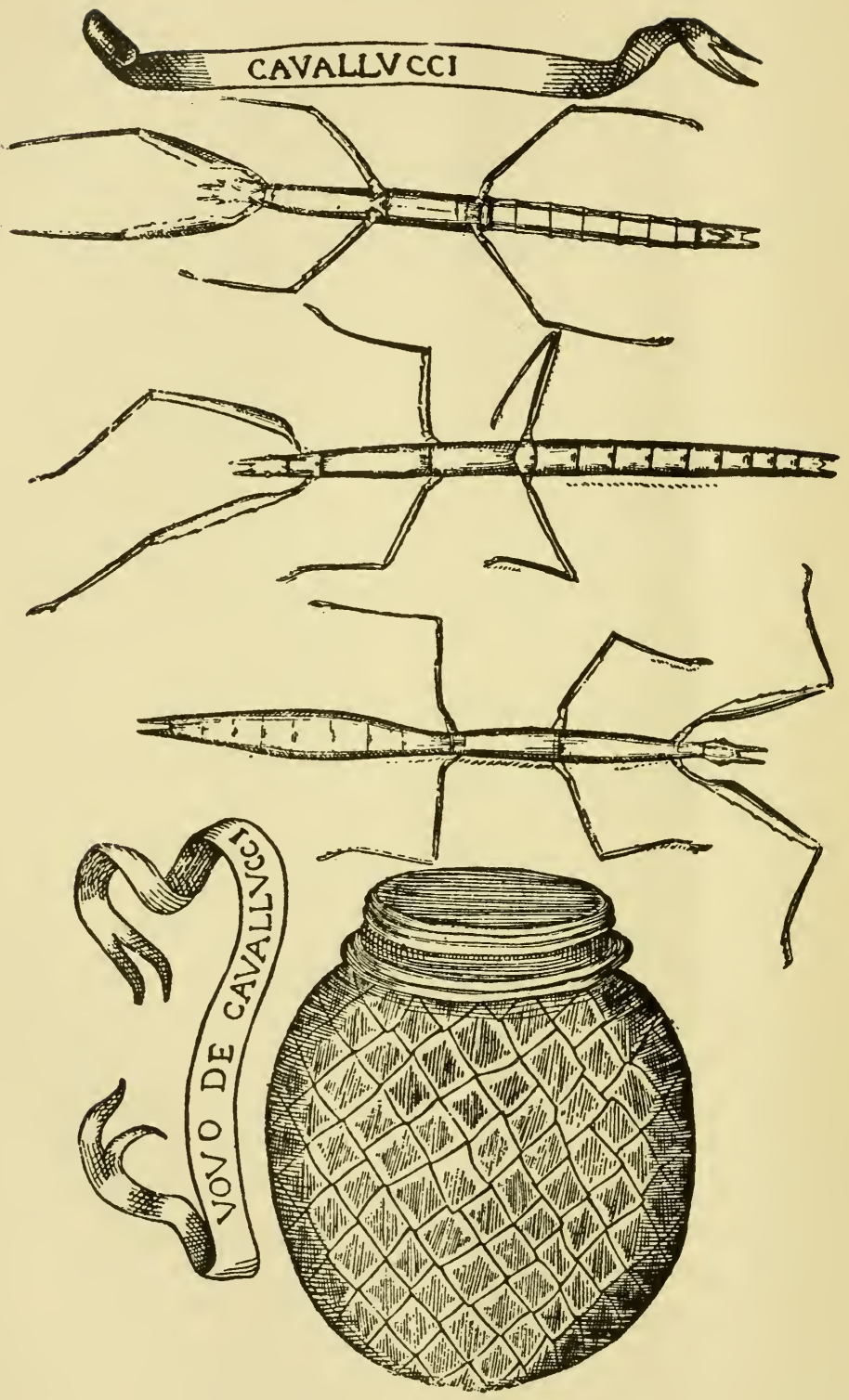


viscous fluid, that oozed from the bodies, and on drying, caused the parts to join firmly together; but though the bodies lived, the heads gave no sign of life; the trunks, with or without the heads, continued to live for five days. In case you should have the curiosity to see how these little creatures look, without seeking them in Kircher or Johnston, I send them to you, here enclosed, drawn from life, together with a drawing of one of their eggs, enlarged by means of a very fine microscope. You will notice that one end is oval and the other has a raised border, which resembles one of those divided, wooden eggs, that we use for boxes, and that screw together in the middle.

I have gone from one subject to another, unconsciously, and must return to my previous remarks about the insects which appear to take origin in rotten plants; and I assure you that I have seen worms occur in all kinds of vegetation. Hence, it is not strange that Pliny and Dioscorides should have vaunted the marvelous discovery that macerated sweet basil, when exposed to the sun, breeds worms. From worms bred in decayed plants I have seen the common fly hatch out, and sometimes a gnat. But often from a single plant there would arise many generations of small, winged animals, so minute that Tertullian had good reason to call them: "unius puncti animalia." I recall that, on hyssop alone, on lavender and St. John's wort, besides flies and gnats, eight or more different generations of midges were born. I also found some worms on parsley similar to those that change to flies, but they were all hairy, and forming a circle with their bodies, would frequently spring about. I was unfortunate in not observing their subsequent transformations, as they all died before forming them- 
selves into eggs [pupæ], owing, perhaps, to the chilly season, at the end of November.

Hear now what Pliny writes in the twenty-first book of his "Natural History": "Another wonderful thing occurs in the Isle of Candia; here is Mt. Carina, which is nine miles in circumference, and flies are never found in this district. The honey made there is never troubled by flies, and is for this reason in great demand for medicinal purposes." Zese relates the same thing about Attic honey, and gives the reason that Attica has great quantities of thyme, the strong odor of which is very disagreeable to flies. M. Glica, in his Greek Annals, is of the same opinion, but I have seen flies lay their eggs, or their worms, in thyme, and have seen the young flies hatch out of them; and these flies would not only greedily eat honey thinned with a decoction of thyme, but would also swallow an electuary composed of honey and leaves of thyme. Perhaps that story may have been true in Pliny's time and on Mt. Carina, but to-day, in Tuscany, it must be classed among fables. Therefore, in order to terminate as soon as possible this long and tedious letter, I will say again that as all dead flesh, fish, plants and fruits form a good breeding place for flies and other winged animals, likewise all kinds of fungi are suitable for this purpose. I speak, however, of fungi that have been picked, therefore dead, so to say, and decayed; for those rooted in the ground and on trees, living, that is, produce another kind of worms, differing in every respect from the worms, issue of flies; the worms coming from fungi do not crawl along, but walk on their feet like silk-worms, and have a short, blunt head, not sharp and long, as in the other case. These worms, then, on attaining full growth, escape from their birthplace in the 
fungus, and instead of changing into eggs [pupæ], they build around themselves a cocoon of silk, in which they remain enclosed a certain number of days, when there issues from each cocoon an insect that is occasionally a mosquito, sometimes a little black fly with four wings, and again a similar fly with an elongated abdomen, like a tail.

Now, whatever may be the efficient cause that produces these worms in live fungus, I, for my part, believe it to be the same that creates them in living plants and fruits, about which philosophers hold most varied opinions. Fortunio Liceto, in his book on the spontaneous generation of living things, being convinced that the vegetative soul, more ignoble than the other, cannot produce the sentient soul, believes that the generation of worms is due to the nourishment that plants take from the ground, in which, he says, there are many particles of the sentient soul communicated to it by the putrefaction of animal bodies, or by their excrement; he further adds that from all bodies, living or dead, many atoms or corpuscles, pregnant with the sensitive principle, are given off, fly about in the air, and attach themselves to the bark of trees, plants, and to their leaves and fruits, and subsequently cause the origin of worms.

Pietro Gassendi thinks that worms breed in the pulp of fruits owing to the insemination of the flowers by flies, bees, mosquitoes, etc., their seeds afterwards developing with the fruit, become worms. I could adduce many other opinions, but they are all similar to those enumerated at the very beginning of this letter, hence I deem it opportune to omit them; but if I must disclose my real feeling in the matter, I would state my belief that fruits, vegetables, trees and leaves become wormy 
in two ways. One way is that the worms come in from outside, and, seeking food, gnaw a path to the very heart of the fruit and the wood. The other way, which I esteem worthy of credence, is to be found in the peculiar potency of that soul or principle which creates the flowers and fruits of living plants, and is the same that produces the worms of these plants. Who knows? Perhaps many of the fruits of trees are produced with a secondary, rather than a primary purpose, not as pre-eminent in themselves, but as objects of utility, destined as a matrix for the generation of these worms, which remain in them for a determined length of time, and thence come forth to enjoy the sunshine.

I think that my idea will not seem paradoxical to you, if you consider the great variety of growths, such as glands, galls, knobs, warts, etc., produced by oaks, holm oaks, live oaks, and other acorn-bearing trees. In the hairy tufts of the oak, and in the woody tufts of the ilex, and in the galls of the holm oak leaf, it is manifest that the first and principal intention of Nature is to create therein a winged animal, for there is an egg in the interior of the gall, and this egg enlarges and matures in proportion to the development of the gall, and finally gives birth to the worm, which, when the gall has reached maturity, becomes a fly, that breaking the egg and commencing to gnaw the gall, makes a narrow and always round road from the center to the circumference, and abandoning its native prison, escapes and flies boldly away in search of food.

I confess to you frankly that before making these experiments in the generation of insects I believed, or rather suspected, that galls were originated by the fly, which, in the Spring, makes a small slit in the young 
twigs of the oak and hides one of her eggs in the opening: the gall arising thence; and I thought that all galls, glands, excrescences, etc., were never seen except on those branches wherein the flies had deposited their eggs; the galls themselves being a disease caused in the oaks by the fly's sting, in the same manner that we see swellings arise in the bodies of animals after they have been stung by similar insects. I was also in doubt whether the galls arose first, and the flies, on coming afterwards, deposited in them some kind of seminal fluid that, pregnant with procreative power, penetrated to the most remote parts, and fertilizing them, produced the worm. But I reflected that there are many kinds of fruits and vegetables, which, though protected by their rinds or pods, still are wormy; and I observed, also, that all excrescences constantly arise in a certain part of the branches, and always in young ones, appearing always in the veined parts, and never on the smooth surface, and invariably on the side of the leaf turned to the ground, and not on the side looking skyward; having also taken into consideration that, when the leaves of trees on which grow vesicles or pouch-like swellings full of worms first bud out, they are even then covered with these growths, as can easily be seen, though they are very minute; these vesicles grow with the growth of the leaves, as anyone can prove to his satisfaction by observing the excrescences on the leaves of the elm, the wild plum, the ilex, and the lentisk. For further example, the holm oak produces some bunches of flowers from which arise the same number of red berries, each of which engenders three or four worms, enclosed in a separate cell. The same tree produces another bunch of flowers, from which arise several greenish-yellow calices, 
having a woody base and soft rim; all these calices make their worms, which come out in the shape of winged animals. Hence, I have changed my opinion, and I think it probable that the generation of worms in trees does not occur fortuitously, nor does it proceed from the eggs deposited by flies, especially as every gall or growth has its own peculiar kind of worm, gnat, or fly, which never varies. It is wonderful with what consummate skill $\mathrm{Na}$ ture forms the egg and prepares a place for it; admirable is the industry and patience with which she surrounds it in a network of fibres and filaments, connecting it with the gall, like so many veins or arteries, which furnish the necessary supply for the formation of the egg and the worm, and the indispensable nourishment of both. Though there are different kinds of galls which produce not only one, but many worms, still Nature knows where they are and provides accordingly, as she does in the case of prolific animals, which give birth to numerous young at the same time. It is also to be noted that the worm of the gall receives a certain vital stimulus from the oak, for if such a growth should be pulled as soon as it appears on the tree, and when the eye cannot perceive any sign of an egg, this gall will not produce a worm, nor yet a fly. If the gall is plucked at a later stage, when it is larger, and the first beginnings of the newly-formed egg can be seen, and the taste is bitter, things will go badly, and the worm will not reach maturity; but if the worm does turn out well, it is because he has enjoyed a full term of development that is invariable; though it is true that different kinds of galls have different times of maturity; in some the insects are ready for flight in the Spring, others in Summer, Fall, or at the beginning of 
Winter, but certain others prefer to wait over a year or two in their cells.

It would be superfluous to make any further remarks on this subject, as some parts are not entirely new to you, such as my experiments made at Artiminio when the Court stayed there last year to enjoy the delightful sports of the chase. So I will keep silence in good faith, begging the continuation of your interest in another work which I am preparing to publish, i. e., a history of divers fruits and animals generated by oaks and other trees. I firmly believe that I shall soon be able to satisfy the curiosity of investigators of natural phenomena, being favored by the royal generosity of my Lord, the Serene Grand Duke, by which means I have already been able to obtain many illustrations for my work from the skillful brush of Signor F. Pizzichi.

Before returning to my argument, I cannot refrain from saying that $I$ do not consider it a great sin against philosophy to maintain that the worms of plants are created by the same natural principle that produces the fruits of the plants; and although in some schools it is held as an axiom that the lower cannot produce the higher, I think this absurd, for it seems to me that the fact alone of flies and gnats being bred in galls is sufficient to remove all doubt. Besides, "low" and " high" are unknown terms to Nature, invented to suit the beliefs of this or that sect, according to the needs of the case. But even if it were true, as the scholastics noisily assert, that the lower cannot produce the higher, I do not, for my part, see what there is degrading or paradoxical in the assertion that plants, in addition to their vegetative existence, possess a sensitive power to which this 
is subordinate, and which enables them to produce animal life. Democritus, who, according to Petronius Arbiter, " omnium herbarum succos expressit, et, ne lapidum virgultorumque vis lateret, ætatem inter experimenta consumpsit," did not disdain to concede sentient powers to plants. Pythagoras and Plato were of the same opinion, as were also Anaxagoras and Empedocles, if we are to believe Aristotle's report in the first book on plants. But the recreant Manicheans impiously went further, as St. Augustine tells us, maintaining that plants possess a soul; hence it was a crime to pull fruits or flowers, or to tear off their leaves and branches, or uproot them. Plotinus was more moderate, for in his writings, though admitting that plants have the sense of feeling, he describes it as being of a dull, latent form as in the case of oysters, sponges, and similar animals, that are called "plant-animals" by the schools. I might cite T. Campanella and many other moderns in favor of this opinion. But I shall not bring in proof Pliny's account, that Pythagoras commanded his followers to abstain from beans, because the souls of the dead took refuge in them, nor shall I tell you about the fabulous power ascribed to these vegetables when macerated and exposed to the sun, which according to the Chaldean philosopher, Zareta, then give forth an odor similar to that of human semen, or if the bean-flowers be buried in a vase underground, they assume the appearance of a child's head. I shall not quote here the precise words of the Greek text, because if you have the curiosity to know further, you can find them in commentaries on L. Diogenes, written by our mutual friend, the academician, Egidio Menagio.

As further proof of the sensibility of plants, it will be 
hardly necessary to recall to your mind the allusions to it by many poets. You remember the bushes of Thrace, animated by the spirit of dead Polydorus, the Gardens of Alcina, mentioned by Ariosto, and the enchanted forests created by Boiardo and Berni. At first, these would appear to be bizarre fantasies, invented by poets solely to amuse the public and to perplex the ignorant:

"But ye, whose minds are clear and of free range, Seek for the doctrine, that perchance is hid Under the veil of verses passing strange."

Hear now Berni:

"All precious things and things of beauty, all Those of sweet savor, fine and delicate, Uncovered in the hand should ne'er at all Be borne abroad, lest, through some evil fate, Such choice things unto filthy pigs might fall. Learn then how Nature with covers ornate Her divers products wisely does provide:

Thorns, scales, shells, pods, and rugged bark or hide, Against the power of sky, of bird and beast. She also hides her gold far under ground, With pearls and jewels rare, that men, at least, May not her secrets e'er disclose unbound. How foolish seekers are, who gaily feast Upon their treasure opened on the ground; They seem to call on robbers and the Devil To spoil them of their goods and do them evil.

For it would also seem that Justice wills (Giving a meed of good to them that strive), That he, who labors and much promise fills, Should be a man of worth, no drone i' the hive. As with deft hand a spoon of salt she spills. The clever house-wife daily does contrive To give to viands a still finer savor, Though even in themselves, they lacked not flavor. 
But when, at eve, the Odyssey you read And learn of fearful wars you can't abide, Where some fair god is wounded in the head, Or lovely goddess - don't be horrified;

For Homer did not mean just what he said;

The good man often to the public lied,

To misle fools, who, even with a glass,

Can hardly tell a horse from a dull ass.

Hence, for fair Reason's sake, do not stop short

At what you first perceive, but pass along.

Under the hull there's stuff of different sort:

To judge a thing by the outside is wrong.

By Jupiter! You'll never come to port,

If you give ear to every tale and song.

Therefore, I pray, take up the hoe of mind,

Dig hard, and sweat - something, mayhap, you'll find."

But, who knows, perhaps Virgil, Dante, and the other Tuscan poets, combined truth with fable in alluding to the sensitiveness of plants. I know very well that there is no conclusive proof on either side of the question, but it is true that plants consume food, grow, and produce seed and fruit, like animals. They eagerly seek the sun and fresh air; they avoid unhealthy shade, twisting themselves aside to escape it, and perhaps, if they had legs, and were not so deeply rooted in the ground, they might flee from attack, or, possessing the proper organs, they might complain and break into lamentations on being injured.

I remember, in connection with this, that being in Leghorn, in the month of March. I saw a sea-fruit, round like an apple, that had taken root in the mud between the cracks of a rock. This fruit resembled an orange in size and shape, and was of the color of pig fungi, but is called sea-fungus by the fishermen. Having gathered it, and wishing to examine its internal 
structure, I began to prick it with a knife, and to cut it open, when I saw that it moved and was sensitive to the touch, as it shrank together, and folded itself up at every prick and puncture; yet in its internal cavity, whose walls were milky white, there was nothing but clear water of a salty taste, and some white filaments, that stretched irregularly from wall to wall. And do not sponges, which many learned men class among plants, also move and shrink when attacked?

In cases of paralysis, it sometimes happens that the sense of feeling will disappear in a limb, though the power of motion remain, and inversely, there will be a loss of motive power without any damage to the acuteness of feeling. Now, who could tell, in this second instance, that the paralyzed and motionless limb had any feeling if the patient had neither mouth nor voice with which to state the fact and complain of the punctures and lacerations made by the surgeon to restore his health? Again, who would ever believe, on seeing the free movements of another limb, that there was no feeling in it, if the sick person gave no sign? Hence motion, wherever occurring is not a proof of feeling, as many insist. Let every one think as he likes, but in view of my experiments, I am inclined to believe that the generation of worms in live fruits, plants, and trees is not accidental, but invariably of the same nature, and that all that class of worms is afterwards changed into winged animals according to the different species. And here I cannot refrain from describing the birth and transformation of one or two kinds, which may further elucidate my theory.

Cherries of all kinds grow wormy on the trees, and each cherry has always one worm; in a single cherry I 
have never found two. The worm is white, without legs, and is conical in shape, like those produced by flies, which I described in the beginning of this letter; as long as it remains in the worm stage, it is solely occupied with feeding and growing, but does not make any abdominal secretions; when it has reached a certain size, it leaves the cherry in which it was born, and seeks a place to settle down, and here, little by little, it shrinks, hardens and is changed into a small, milky white egg [pupa] from which nothing hatches for a year, when, on the arrival of Summer, a small fly escapes from it, which is black and hairy; the hairs on the head and back, though rarer, are longer than those on the belly; on the back there is a half-circle of a gold color, and the head is striped with yellow also, from which proceeds a similar large streak of color, that covers a large part of the space between the eyes; the wings are white and covered with gray or black spots, so beautifully arranged that they resemble falcon feathers; there are six legs, also black, hairy. and touched with gold at the joints. You will be able to have a better idea of it from the accompanying drawing, in which the worm is shown together with the chrysalis into which it is changed and the fly, that hatches from it; these appear in natural size and also on a larger scale, as viewed through a microscope of one lens.

Very different from the cherry worms, are those which are found in green filberts, for these are shaped like a half cylinder and composed of white semicircles; the head is auburn and shiny; they do not move quickly, and have six very small legs, placed in three rows near the head. I have never been able to observe the transformation of these worms into winged animals; hence 
it may be that they live and die merely worms. I have often shut up some of this kind for a long time without food, and certain ones kept alive from July to November. Other worms, not dissimilar, but larger, red and hairy, found in red beets and leeks, also maintain life when enclosed in vessels for a long time, nor are they ever

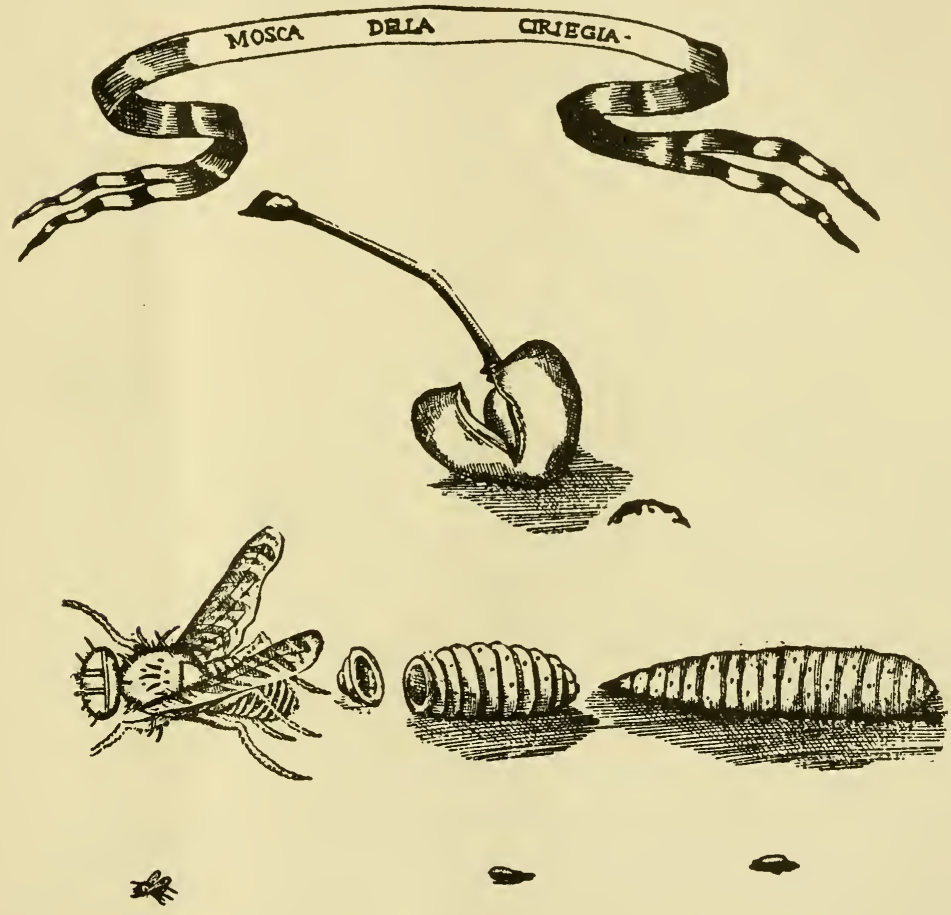

changed into animals having wings. It is therefore not easy to determine whether the worms of the filbert are generated by direct procreation of the tree, or whether they have come in from outside; in view of the fact that all other plants engender, themselves, the worms it would seem probable that the filbert should do likewise, on the 
other hand, the argument that the worms enter from without, is not to be waved aside, for it may be observed that all the wormy filberts, from which the worm has not already escaped, have a small hard projection on the shell, that is perhaps the scar of the aperture made by the worm when it was of small size, and working its way through the soft shell of the nut, penetrated to its internal cavity; the aperture, after the shell grows and hardens, closes, so that the worm, having grown, must make another and larger hole when it wishes to escape, which is indeed found in all filberts abandoned by the worm. I am therefore in doubt what to believe, and cannot come to a decision, although on the authority of a very learned philosopher, I should be inclined to think that the worms of filberts come from outside. This philosopher is the famous Joachin Jung, of Lübeck, who refers to this subject in his Memoranda on Physics, that have been collected and printed with notes by Martin Vogel, of Hamburg, a writer of great reputation, and a friend of mine.

The worms of the plum are similar to those of the filbert, but they move more briskly and with greater speed. They stay within the plum, where they are born, feeding on the pulp and excreting, until they are perfectly grown, when they abandon the fruit, and every worm builds a small white cocoon of silk, from which it subsequently issues in the form of a little gray butterfly having black spots on the tips of its wings. The worms of the peach and pear are of the same kind as those of the plum, and make cocoons from which butterflies emerge.

Perhaps the question may arise in your mind: are all kinds of butterflies generated by trees, or do they come from the parent through the stages of egg and worm? 
The writers on this subject disagree, so I will briefly tell you what I think about the matter, without reciting the opinions of others. The males unite with the females, and their fertilized eggs are laid in great numbers; from these eggs worms hatch, that we call caterpillars, and in Latin " erucæ." These caterpillars feed on the leaves of trees and plants up to a certain time. In the meantime they frequently become torpid and cast their skins. But when they have finished growing, some of them weave a silk cocoon about their bodies, others do not make a cocoon, but shrink up, harden themselves into a chrysalis, and during this process they emit two or three silk filaments, with which they securely attach themselves to a tree-trunk or stone; others of a different kind, remain unattached and float in the air. Finally the butterflies escape from the cocoons as from a tomb, every kind having its fixed period of maturity: some come out after a few days, others delay for weeks, still others for months; and the caterpillars of the third kind, after forming a cocoon towards the end of Spring, do not appear as butterflies until the following Spring. A certain kind of fly also proceeds from a chrysalis.

Do not marvel at all these strange births and transformations, for we ourselves, are nothing more than caterpillars and worms; hence the divine poet gracefully said of us :

"Perceive ye not that ye are merely worms, Born to create the angelic butterfly."

As I greatly desire to demonstrate to you the truth of the foregoing statements, I have pleasure in relating here a few experiments out of many that I have made with caterpillars and butterflies. 
On the fifth of June, on my way to the Villa of Poggio Imperiale, I saw a great many caterpillars crawling about on the holm oaks, which border the road. Some of these would descend by means of silky threads and on reaching the ground, quickly pull themselves up again by the thread. Having ordered a large quantity to be gathered, I noticed that they were all covered with long hair, some being black, and others red; they were all spotted on the back with fourteen dots. I put them in special boxes, where they lived for several days on the oak leaves, then, having divested themselves of their hairy tunic, it seemed as though they were about to prepare a cocoon, but either from lack of material, or, as I believe, because it was their habit, they did not finish the cocoon, but inside the network of filaments, already begun, they changed into chrysalides, that were first reddish, then blackish and shaped like a cone, on the base of which a few hairs remained. On the 26 th of June there issued from them some butterflies, formed like those that come from the silk cocoons, with the difference that the last are white, and the former of pale brown with black tracings and two long antennæ on the head, and a black silk tassle on the end of the belly; but on the twenty-eighth day the other chrysalides opened and let out smaller butterflies, that were entirely white; two of these having united, the female laid a great many eggs, small and yellow, which produced a like number of very small caterpillars in the following May.

On the $5^{\text {th }}$ of July, I found a very large caterpillar on a plant of nightshade. As soon as I had put it in an enclosed place, it began to gnaw the leaves of the plant that I gave it; and on the seventh day of the same month it shed its skin, and remained in the shape of a red chrysalis, 
which grew hourly darker and finally blackish; from it, on August second, there came out an immense butterfly, which, on being irritated, squeaked like a bat. It was of gold color and had black wings, back, and belly. Its head was all black, and from it protruded two black crests; the eyes were brown and the black proboscis was cartilaginous, and rolled up in front of the mouth in many rings, as is the case with all other butterflies; the six legs in the first section, or shin, attached to the thorax, were all hairy and of dirty gold color; the other sections were purple; at the end of every leg there was a nail, claw, or hook, which also appeared in all the articulations of the legs. It lived only six days.

On the twelfth of July, an oak branch was brought to me, on two leaves of which were spread in good order more than thirty caterpillars covered with white short hairs, and spotted all over the body with divers colors; the head was brown and shiny, and crossed by the letter $\mathrm{Y}$ in yellow. All these caterpillars remained motionless and slept peacefully. Then, having placed them in a large box, they shed skins, awoke, and immediately began to devour the oak leaves; and they continued to feed on these until the 22nd day of the same month, when, having settled down in regular order in a corner of the box, they again went to sleep and slept for two whole days, whereupon having shed their skins again, and having aroused themselves, being now much larger and more hairy, they fell to eating with great voracity and held their own, until the first of August, on which day they suddenly left off eating and became stupid, torpid, and weak; they appeared to have dwindled in size; all their hairs had dropped off, and they scarcely moved even when touched; to sum up, they seemed to be depressed or sick, re- 
sembling those silkworms that sicken and almost spoil before they make the cocoon and are vulgarly called "cows." In this state they remained until the night of the fourth of August, when six of these caterpillars, having shed their skin for the third time, changed into chrysalides of a blackish color, resembling so many babies in swaddling clothes. I had occasion on the following morning to see the way in which these caterpillars transformed themselves; the external skin opens at the back near the head, separating from it and cleaving into two parts, and from the cleft the chrysalis begins to come out, writhing constantly, twisting, and contorting itself, until it has pushed all the skin down to the end of its tail; in the meanwhile the head grows noticeably larger, and the tail becomes thinner, so much so that when the process of transformation is completed, the chrysalis has taken on the shape of a cone, is soft to the touch and of a green color. But the green color, beginning from the end of the tail, changes over the whole body, little by little, and with this change of color the skin hardens; the neck is the last part to change, but when it has turned red, then all the rest of the chrysalis has become black and has entirely hardened. This process is begun and ended in scarcely more than half an hour, as I have had ample opportunity to observe on many occasions. When all the caterpillars were changed into chrysalides, which was on August sixth, they retained this shape until the following Spring, and then near the end of April, the butterflies were born: they were all of the same kind, but did not appear at the same time, as the caterpillars had taken on the chrysalis stage at different times. Many of these butterflies, soon after birth, laid their eggs to the number of thirty or forty at most. 
These were of a faded sky blue color, with a small black spot in the center; but as they had not been fertilized by males, they did not hatch anything at all.

In September, at Poggio Imperiale, I ordered a large quantity of greenish yellow caterpillars to be gathered; they were feeding on cabbage-stalks. I put them in boxes, giving them the same food, i.e., cabbage. After four days, they all climbed to the lids of the boxes, and fixed themselves there motionless; during this time some had laid minute eggs, wrapped in yellow silk. After remaining quiet for three days, they shed, not all, but that part of the skin which covers the head; then slowly they began to change shape and the skin commenced to harden; they remained firmly attached to the boxes by means of silken threads issuing from the tail and supporting different parts of the body. In this guise they remained all winter, but towards the month of March, many became dry and ceased to move when touched, others remained alive, with the power of partial motion and these, abandoning their shells that still held to the boxlids, escaped in the shape of pale, greenish-yellow butterflies, having two round black spots on the upper wings and two yellow horns on the head. Being led by curiosity to open some of those chrysalides that had become dry, and had ceased moving in March, I found that the shell was empty, excepting in the part corresponding to the chest, where I discovered a reddish purple egg, full of matter like milk or white of egg. On May I Ith, from all these eggs there hatched flies of the kind that ordinarily inhabit houses. These were at first heavy, dull and misshapen, like those, described at the beginning of this letter, and which originated from worms bred in meats. In the meanwhile minute eggs, 
laid by the caterpillars in September, hatched out very small, black gnats, having two long, black antennæ on the head.

I tried a great many other experiments, and made many observations, but owing to carelessness, some pages, on which I had inscribed them were mislaid; hence not wishing to trust to my memory, I shall pass on and tell you that it is possible that there is some kind of tree, which can engender caterpillars, undergoing the usual transformation from chrysalis to butterfly. I do not affirm this, neither do I deny it, and in order that every one may believe as he chooses, I will continue my report. In the same year, at the beginning of May, I noticed a great many berry-like growths, or little green balls on the rough side of the leaves of the osier. These were larger than a cherry stone, and towards the end of May became red, sprinkled with white; they were but lightly attached to the leaf and were yellow inside the large cavity, in which a caterpillar was always found, that was very slim and white, with a brown head, and was intent on feeding and on excreting. From the beginning of June to that of October, I continued my investigations to ascertain whether the caterpillars come out of the balls and are subsequently transformed into butterflies, but I never had the good fortune to find a single one with a hole in it. I was not able to make any discovery with some that I enclosed in jars, for after ten or twelve days, I always found the caterpillars dead in the hollow of the leaf-ball. There is another kind of osier, that does not produce these red balls in the leaves, but has instead warts or knots on its branches, in which caterpillars, similar to those mentioned above, are bred. I was equally unable to find out the ultimate transformation of 
these. On May 29th, some branches of willow were brought to me, on the leaves of which were small tumors or welts of green color, that were beginning to redden. The welts were long and smooth like beans; they were not placed like the osier balls on the side of the leaf turned towards the ground, and therefore easily displaced, but arise on both sides of the leaf that envelops them, are situated near the large central vein or nerve, and are found to the number of two and sometimes three on a leaf. I observed several and found that they contained a white caterpillar like the one found in the two species of osier, and I observed also, that many of these welts had been pierced, and in their cavities there only remained the excrement of the caterpillar, which had already escaped; whereupon I became hopeful of seeing the transformation but in vain; for although I carefully kept my leaves enclosed in boxes, the caterpillars would never come out, and after a few days, I invariably found that they were dead. As you may possibly be curious to see how the plants look that bear the caterpillars, and of which generation the herbalists have not made mention, as far as I know; I send you drawings of them herewith, calling your attention to the fact, that the smaller drawing of the caterpillar is its natural size, and the larger, its appearance under a microscope of ordinary power.

I do not know of any other caterpillars produced by trees, but Father Kircher repeatedly states, in the twelfth book of the "Subterranean World," that the mulberry tree produces the silkworm, on being impregnated with the seed of any chance animal, which penetrates the substance and the juices of the tree. In order to ascertain the truth of this statement, I not only studied the trees 


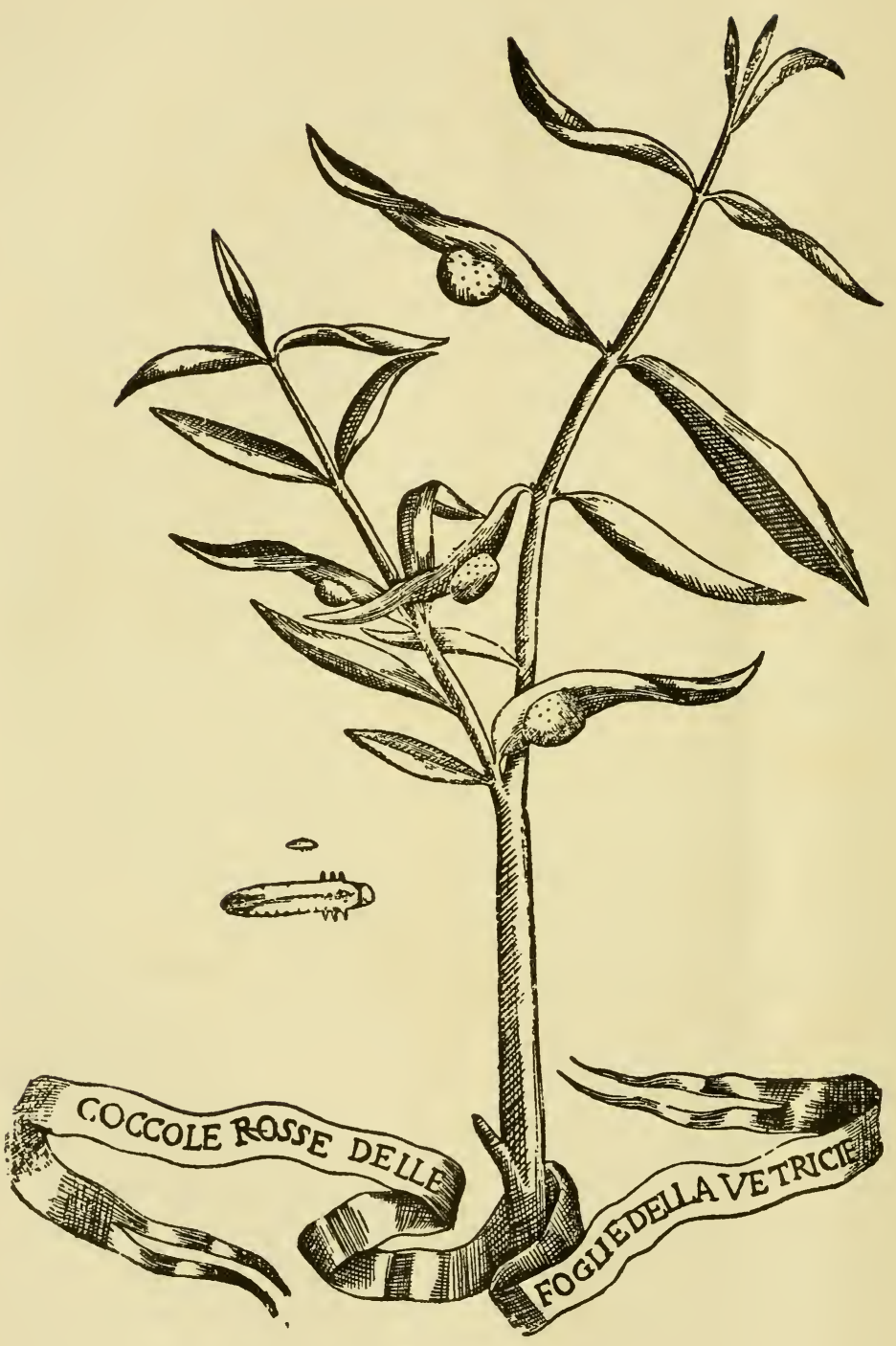




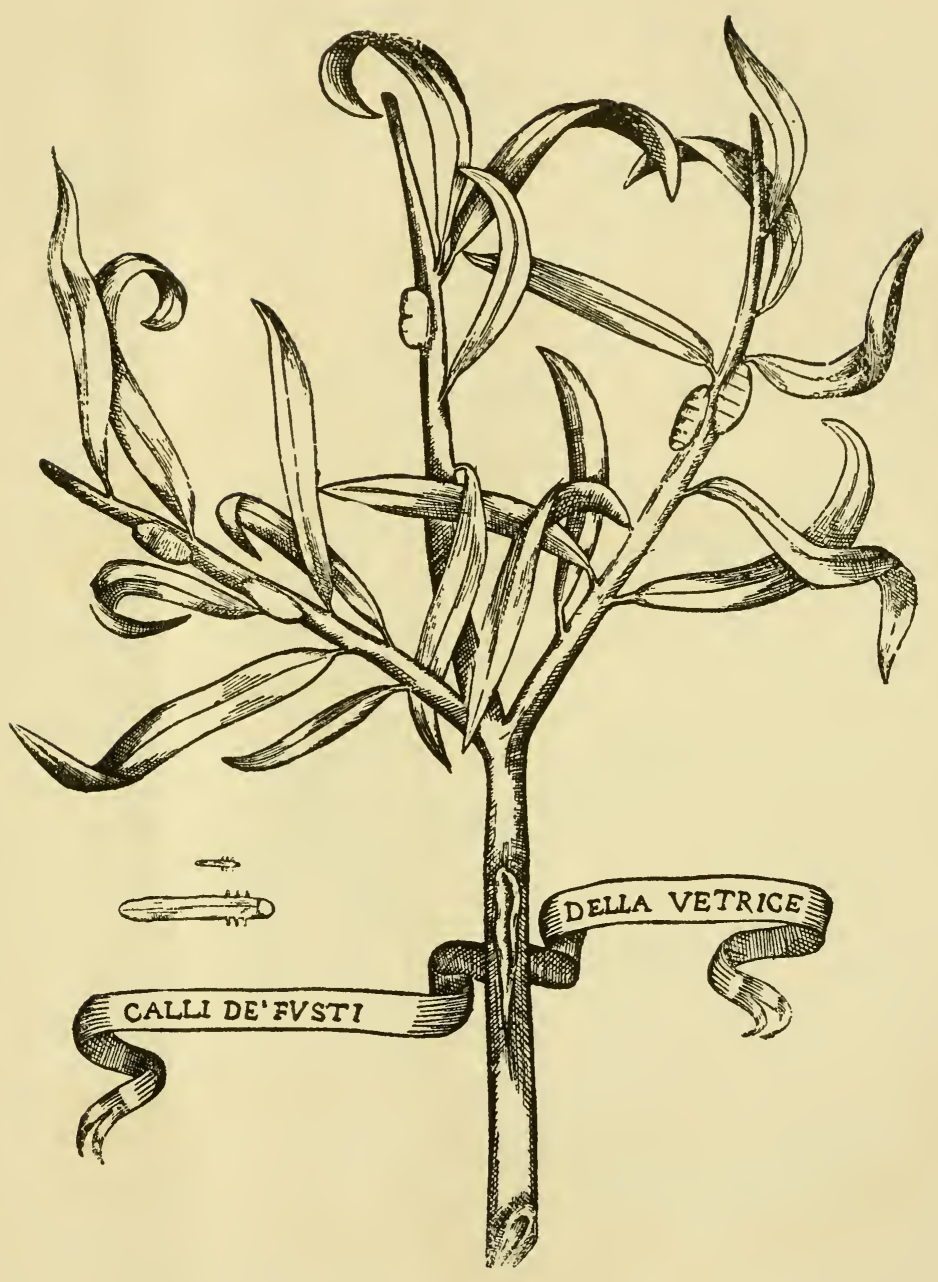




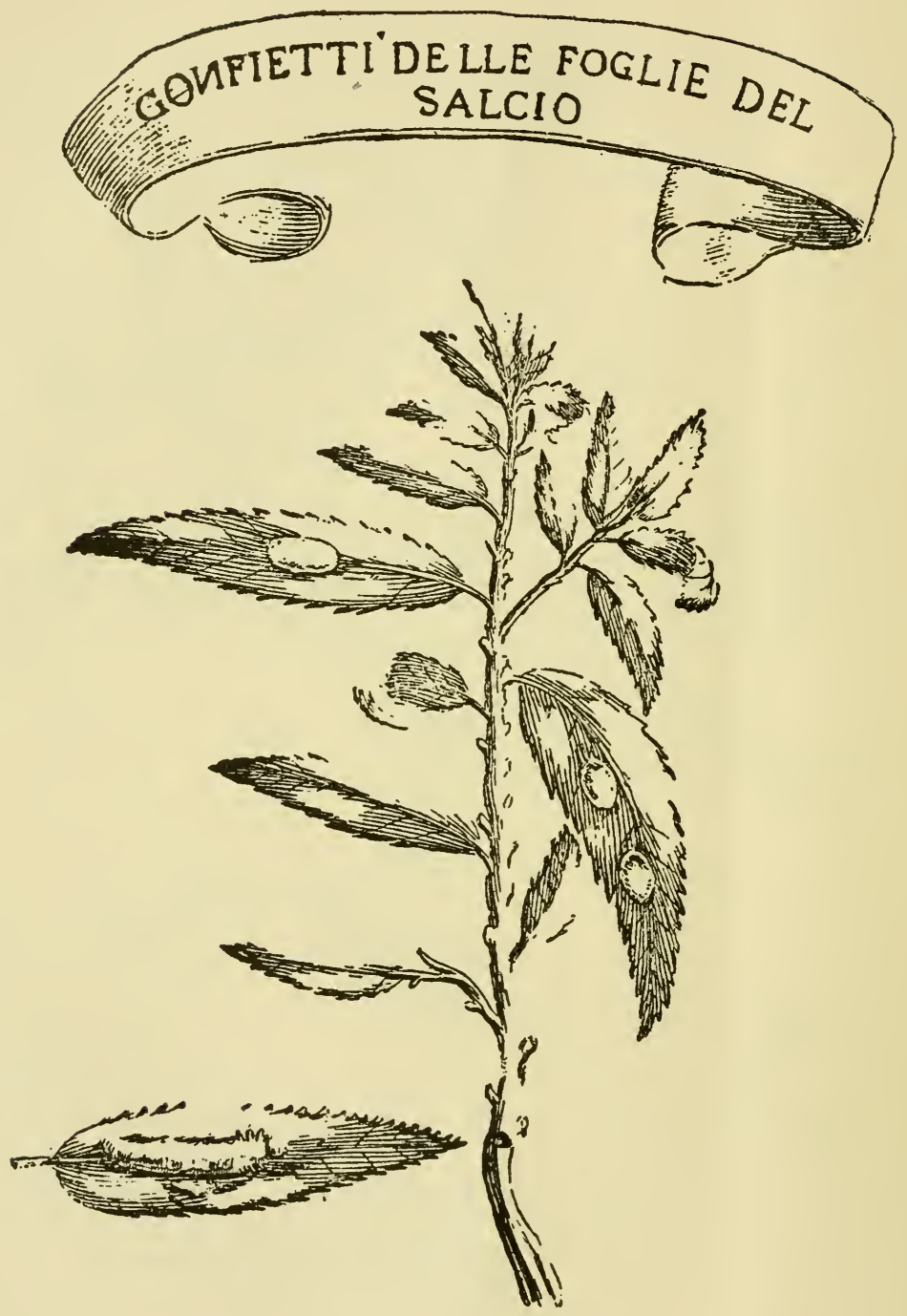


around Florence with great care, but also those of many other Tuscan cities, but I was never able to see any sign of such propagation.

Aristotle asserts that cabbages produce caterpillars daily, but I have not been able to witness this remarkable reproduction, though I have seen many eggs laid by butterflies on the cabbage-stalks and neighboring grasses; these eggs developed subsequently into caterpillars and butterflies.

Whoever has observed trees and plants will have often found similar eggs in the cracks of the bark, and I remember, that at the beginning of May, I found a great many tiny, yellow eggs on the leaves of the elder tree. I took pleasure in observing what would hatch out of them, and in a few days, I saw an equal number of very minute worms come out of them, which I immediately supplied with elder leaves, that they greedily devoured. They continued to grow and became a yellow color with many reddish spots; the tail ended in crescent shape, and the head was very small and sharp, and when they moved, they pushed out ridge-like protuberances, that served the purpose of legs. The greater part of these worms ceased from motion and left off eating on the 26th of May, without, however changing their shape or color; but on the first of June, six of the said worms shrunk together and rolled themselves into balls, looking like eggs humped in the middle and pointed at the ends; they were of rust color. From one of these balls, on the I th of June, a fly escaped, not much larger than the common fly, with two cartilaginous wings, white and longer than the body; with six yellow legs, and two short horns on the head, that was rust colored. The back was of a lighter color with a large yellow spot. 
The rest of the body was yellow crossed with lateral black stripes. As soon as the fly hatched, it began to excrete a kind of white dung. It lived only five days.

The other five eggs hatched seven days after the first and there came out from them as many flies, very different
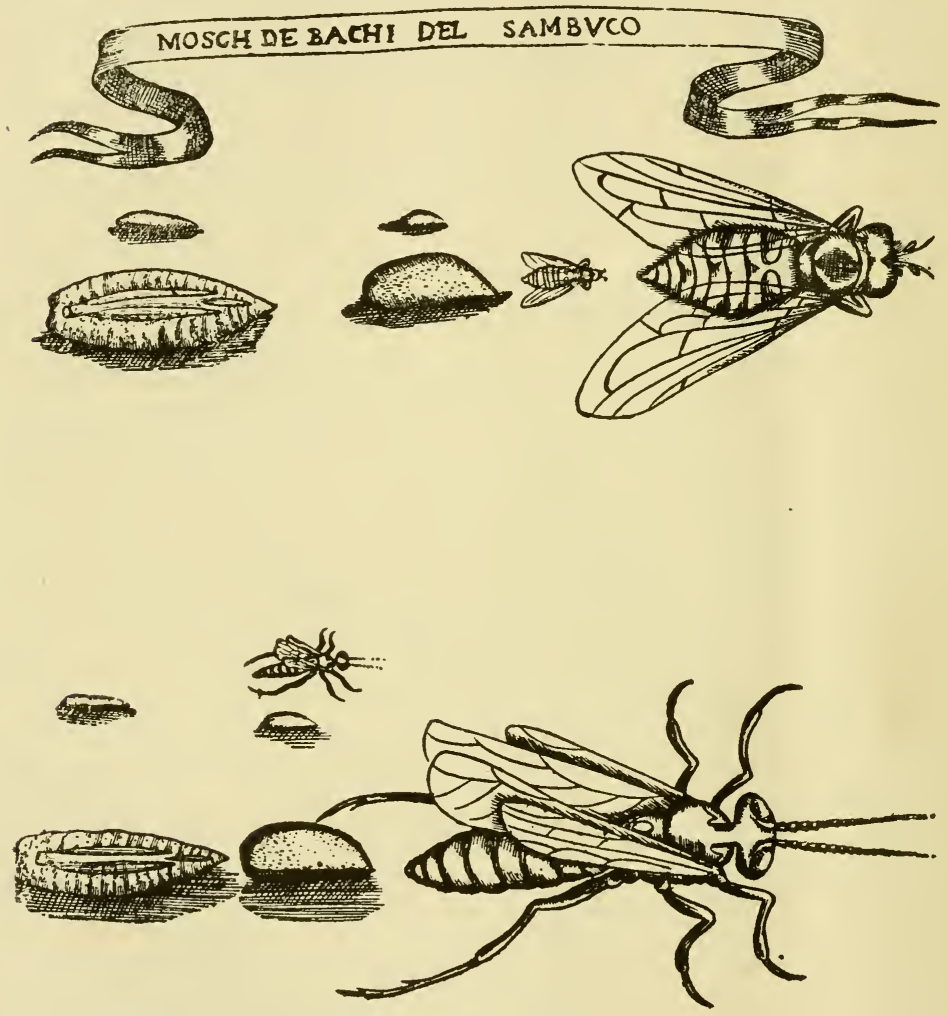

from the one which had come out from the first egg, although they were of the same color, in as much as these five were long and slim with their wings very much shorter than the body. These wings were not two, but four. They had six legs, two of which were very much 
longer than the other four. From the heads came out two very long pointed antennæ, composed of many and many knots. These flies, like the first, as soon as they were born, emitted a white substance, and lived four days. I observed, however, that when these worms found on this plant transform themselves, contracted in an egg [pupa], the egg becomes smaller than the worm and when from the egg the fly comes out, it is very much bigger than the egg, to such a point that it seems impossible that it can have got into it. So one can believe that it was very much crowded in it, and cramped. Because my brain gives me little help in describing exactly these small animals I send them to you drawn, and in their own and natural size, and enlarged also by an ordinary microscope of those of only one glass.

But as I have not been able to observe, as stated, that the mulberry tree engenders silkworms, still less can I expect to see them breed in the decayed flesh of a mule, fed for twenty days on mulberry leaves. This fabulous belief has been elegantly described by the distinguished poet, Girolamo Vida, who sings in imitation of Virgil:

Quod si spes generis defecerit omnis ubique, Seminaque aruerint Iovis implacabile ira;

Sicut, teneri reparantur caede iuvenci," etc.

I do not know what to say about this, but I do know, by experiment, that the flesh of a kid, which had been fed on mulberry leaves alone, for twenty days, did not produce anything but worms, that were transformed into gnats. I know also that worms breed in rotten mulberries, but always on condition that insemination has taken place previously, otherwise, as before stated, nothing will be produced in plants, carrion, or any other life- 
less thing. On the other hand, if the thing is alive, it may produce a worm or so, as in the case of cherries, pears, and plums; in oak glands, in galls and welts of osiers and ilexes worms arise, which are transformed into butterflies, flies, and similar winged animals.

In this manner, I am inclined to believe, tapeworms and other worms arise, which are found in the intestines and other parts of the human body, also in the gall and the liver of sheep; and likewise those other disgusting
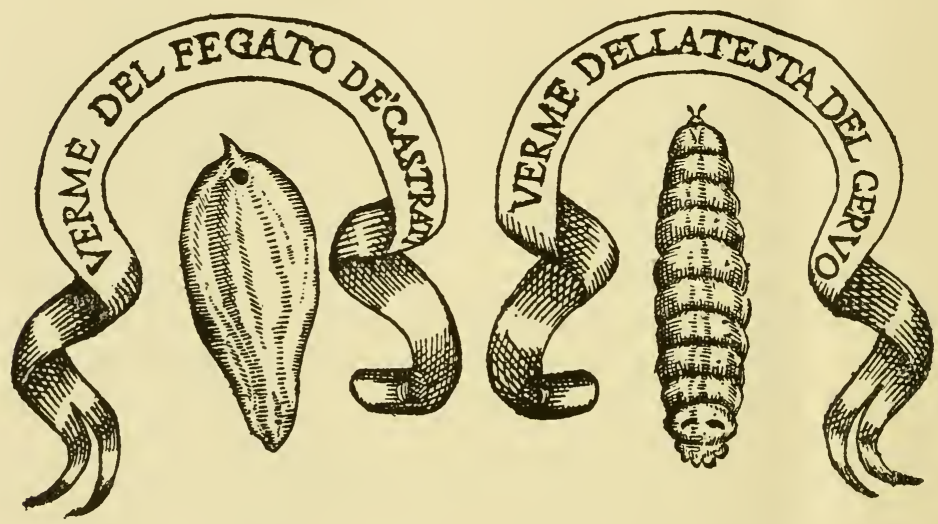

little worms found in the head of deer and sheep. As it may be a new thing to some persons, that worms are found in the liver of sheep and in the head of sheep and deer, I willingly undertake to briefly tell you what I have observed, and herewith send you drawings of both kinds of worms, of the largest size to be found.

Liver-worms of sheep are shaped like a pumpkin-seed, or more exactly, like a small, narrow myrtle leaf with part of the stem attached; they are milky white, with many fine ramifications of veins or canals. The mouth, or whatever the opening may be called, is round and placed in the middle of the belly, not far from the part 
that resembles the stem of the myrtle-leaf. These worms are often found in the gall bladder and not only live and swim about in the gall, but also inhabit all parts of the liver excepting the arteries, in which I have never found any. I think, however, that they are born in the gall bladder and make their way through the bile duct to the blood vessels; then if they multiply excessively, they eat into the inner substance of the liver, and make cavities in it, which fill up with blood mixed with bile; this stagnates, thickens, and becomes of a rusty color mixed with green, ugly and disgusting to the sight and very bitter to the taste; so that anyone, who saw this process, would never care to eat liver again; though it must be said that butchers cleanse the meat of all this dirt before placing it on sale.

Aristotle, the great and wise philosopher, in chapter fifteenth of the second book of the "History of Animals," describes the worms of the deer's head in these words: "All deer have live worms in the head, which are born under the tongue, in a certain cavity near that vertebra, by which the head is attached to the neck. They are larger than the largest worm, that originates in carrion, and they number at most twenty." Impelled by curiosity, I made many investigations with old and young deer, and found worms in almost all cases. On the $27^{\text {th }}$ of February, out of ten deers' heads opened for my examination, nine had worms in them, only a single one being free from this pest. Aristotle compares them in size to the worms usually found in decayed flesh.

"Because he's Aristotle, it implies

That he must be believed e'en though he lies."

But these worms, of the deers' heads, seemed to me incomparably larger, and not at all like the others in 
shape; those that infest the deer are formed like a half cylinder, are flat underneath and rounded above, of white color, but marked with many hairy semicircular rings, in which the hairs are rust colored. They have two very small white horns on the head, which they extend and draw in at will as snails do. Under these horns are two claws or hooks, black, hard and very sharp; it would appear that they use these hooks to crawl along, holding on by them, and dragging the body after. The end of the body, whence the excrements are discharged, is crossed by a duct, which is indicated by two black, semicircular spots. The number of these worms is not invariable, though Aristotle has limited it to twenty; nevertheless I have counted as many as thirty-nine in a single head, but never less than twenty.

Very similar in shape to these worms are those found in the heads of sheep; but they are smaller, less bold, and less hardy, and are only marked with transverse stripes, which are very black and stand out vividly from the svhite body. Only the large adult worms are thus striped; the small or young ones are all white. The two black spots like half moons, seen near the excreting duct of the worms of the deer's head, are perfect circles in those of the sheep. These worms inhabit certain cavities in the frontal bones, where the horns are set in. I have found them in the nasal passages and in the cavity at the base of the horns. Hence Caporali's agreeable verses, in the life of Mæcenas, wherein he alludes to the nature of love, are correctly stated:

Some say that Cupid, God of all the Loves, Is part a child in form and part a bird, And like a falcon fierce feeds on the heart. Still others say, as I have often heard, 
That $\mathrm{He}$, whose wounds do sting, and burn and smart, Is but a worm, like that of the sheep's head, Which underneath the curving horn is bred, And deeply gnaws the tissue of the brain; Thus does Love madden with excess of pain."

Shepherds say that, when at certain times sheep become frantic, as if stung by hornets, their excitement is due to unusual activity on the part of the worms, infesting the head. They are not so numerous as those of the deer, and seldom exceed twelve or fifteen at the most. And here please remember that I limit my statements to those things, that I have seen with my own eyes, and make no affirmations nor denials concerning anything else.

That same vital force, that produces the worms of which I have been speaking is the possible cause of those other abominable and odious creatures called " $\phi \theta \epsilon i \rho \epsilon s$ " by the Greeks, and which infest the external parts of men, quadrupeds and birds; but, if I must express my thought freely, I will say that I am more inclined to believe with the learned Johann Sperling, that they originate from the eggs of the females, fertilized by coition. And though Aristotle, followed by most moderns, gave out that those eggs, or nits as they are called, never produce any sort of animal, he most certainly erred, for they multiply ad infinitum, and it seems useless to prove such an obvious fact. The hair of quadrupeds, and the plumage of birds, are frequently found to be full of those nits, which, though so minute that one needs good eyes to discover them, by the aid of the microscope they can be seen very well, and the full eggs be distinguished from those that have hatched. Anyone inclined to dispute this fact, and to cry out that there was some distortion, produced by the microscope, can 
find satisfactory proof in the eggs attached to the feathers of the royal eagle, the kestrel, and the cow-bird, which is also a bird of prey; these eggs are much larger than a grain of millet, hence the naked eye can discern them and even see the well-formed lice inside, as I have frequently done, thus learning what a weak foundation sustains the statement of Aristotle, and with what slight effort it may be overthrown.

It might perhaps be affirmed, without doing injury to the truth, that all kinds of living creatures are exposed to this noisome pest, and as for Pliny, who wished to exempt asses and sheep from it, I can excuse him, for he relied on the report of another person, that is, he believed in the statement of Aristotle, in the "History of Animals," which statement was confirmed many centuries later by Thomas Moufet, in his praiseworthy "Theatrum Insectorum," in which, not wishing to refute the sayings of that profound philosopher, and racking his brains for an evasion of his dictum, he wrote that the ass does not become lousy because of his natural disinclination for exercise, owing to which he is rarely in a sweat. Afterwards, it occurred to Moufet that the above reason was frivolous and of little weight, so he retreats to the last refuge of logic,, namely, antipathy. In spite of all this conjecture, it is a fact that the ass is subject to lice, and I have reproduced these pests in the following pages, together with those infesting the camel. The most ignorant shepherd knows that sheep are likewise troubled with this vermin, and the Greek, Didymus, speaks plainly on the subject in book eighteenth of his "Country Life." And since his time, Jacob Alfiruzabadi names these plagues in his great Arabic Dictionary, which was called by the Egyptian title "Alcamus," that means Ocean. 
The above mentioned Moufet reports that even beetles are tormented by just such ugly little creatures, and, though I have not had occasion to verify this by observation, I am persuaded that it is true, as I, together with many others can bear eye-witness that even ants are not exempt; and that every kind of ant has its special variety; but it is necessary to have sharp eyes, armed with a fine microscope to discover the lice, for they are so minute as to be almost invisible, and one might be tempted to class them with atoms. The vermin of winged ants are shaped like the hen's tick, which may be seen drawn on plate 2, and those of wingless ants are similar to the ticks infesting the turtle, which also may be seen on the second plate.

Writers in natural history make an assertion, confirmed by all fishermen, that fish are also molested by various kinds of insects, among which the best known are the flea, the louse, and the sea-bug (cimex marinus). Aristotle wrote of this in connection with dolphins and tun-fish; others have affirmed the same in the case of salmon and sword-fish. Pliny speaks of it in a general way, saying: "Nothing exists on the earth which has not its counterpart in the sea. Even those little beasts can be found there which infest the inns in summer, and hop about with annoying celerity, and also those, that hide in the hair. When the hook is drawn from the water, they are often on it; and these, they say, are the pests which at night disturb the sleep of fish in the sea." In order that you may more easily give your adhesion to the authoritative opinions of these approved writers, I will not omit to tell you that, in the month of March, as I was seeking sea-urchins, on the Melloria reef, I saw some little animals caught in the bristles of numerous 
sea-urchins, which were of the same color as cray-fish and were similar in size and shape to " porcellini," though they had no horns, but two very small black eyes and sixty slim legs situated around the edge of their shell; and I hold that Aristotle had them in mind, when he wrote chapter 3 Ist of book 5 th of his most useful "His-

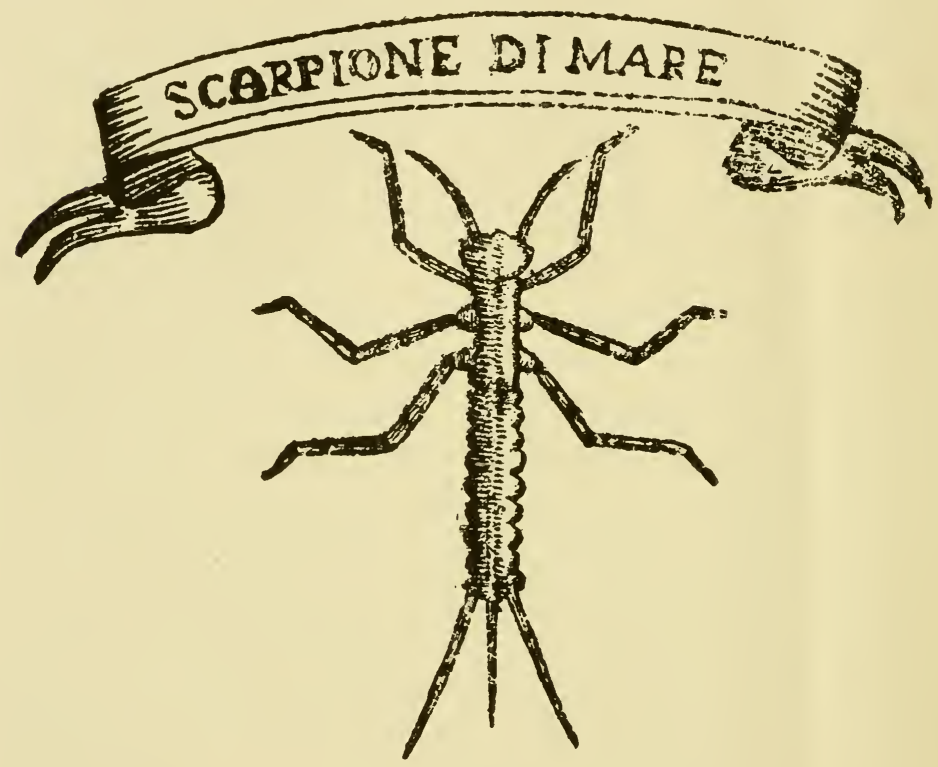

tory of Animals." Several days later I found, in the joints of the sea-locust's shell, another insect, called by fishermen a sea-scorpion. I dare not say whether this was due to accident, or was of usual occurrence; in either case I am inclined to subscribe to the dictum of Aristotle, who asserts that aquatic insects do not breed on the external parts of fish, but arise in the slime, which is, in my opinion, the nest in which the eggs of insects are deposited and hatched. 
Through the princely generosity of His Serene Highness, my Lord, the Grand Duke, I obtained a seal, last winter, which lived out of water four whole weeks without food, and would have lived much longer, if it had not been killed for the use of the Pisan anatomical theatre. During the time that I kept it, I tried many times to ascertain if there were any parasites hidden in its thick, soft fur, but I found nothing of the kind. On the other hand, all birds that dive for prey under water and haunt the swamps and pools, have great quantities of lice, that live in their feathers all the year round.

As I have again mentioned the subject of lice, it will not be inappropriate to speak more in detail of what I have found out concerning them by means of many experiments. Lice are found on all birds, and each kind of bird has its own particular species. I found three kinds of lice on falcons and on guinea-fowl; four on wild duck, two on the swan, the royal wild goose, the kestrel and the plover. It is however true, that some birds have similar, nay even the same kinds of lice, for the royal eagle has large ones such as are found on the kestrel, shown on plate I3. The cow-bird has some similar in shape, not in color to those of the crow, which are represented on plate 16 , and the eagle has others like the oval ones of the falcon. A kind of lice found on the bustard, resembles greatly the long-bodied ones of the falcon, plate I. The woodpecker has the same kind as the starling, plate 2 . The lice in the feathers of the crane are all white, plate 3 , with curious black tracings like arabesques. The same kind, to a hair, are found in some birds, kept in the Boboli Gardens, and lately brought from Africa, where they are called "Bukottaia" by the Arabs; some consider them to be another kind of crane, because 
they greatly resemble the common crane in shape and color, though smaller and more slender, having besides two long white tufts on the head, which makes me think that they belong to the species of Balearic cranes.

All the foreign birds, kept in the above mentioned gardens, have been examined by my order; but at no time were any lice found on ostriches; a stork also was exempt, but that may have been mere chance, as there was only one stork, but there were twelve ostriches, which had lately come from Barbary. The size of the lice does not correspond to the size of the bird, as large birds have both large and small lice, and likewise small birds have large lice, as I recall having found lice in blackbirds, which were not inferior in size to those of the stork.

Now when the lice are observed from above, the mouth is not seen, but when they are turned over it appears plainly, situated on the part of the head, turned to the ground; it is fashioned like a pair of pincers, similar to those arming the mouth of the wood-worm. If you will take the trouble to look at plate 8, you will see this portrayed in the engraving of the swan's louse. The different kinds of lice are indeed so varied and so peculiar, that instead of making a tedious enumeration of them, I have preferred to show you some drawings of them, made at my request by Sig. F. Pizzichi, which I subsequently had engraved in the best manner possible and consistent with the brief time at my disposal. As regards the color of lice, it is very similar to that of the bird's feathers, which they inhabit; but experience has taught me and I firmly believe, that when the lice hatch from the nits they are all white, but afterwards with growth they slowly become colored, retaining however 
always their transparency, so that when viewed through the microscope, and enlarged thereby, it is easy to see the movements of their viscera and the liquids contained therein. In order that you may surmise the real proportions of these little animals, I will not omit to say that in drawing them the same microscope was always used; it is of three lenses and was made in Rome with great skill and accuracy by Eustachio Divini.

With the aid of this single microscope, three kinds of winged ants are reproduced in the following plates, also the grain weevil, the worm that eats into candied fruits and spice, the bug which explores the head and back of man; and that other kind that lurks in the hairs of the loin; the louse of the ass, of the camel, and that of a certain sheep from Tripoli. There is also a drawing of the tick of the wild goat, and likewise one found in the tiger. The lion's tick has the same shape as that of the tiger, but it is different in size and in color; the lion's tick is much larger and is of a light yellow color except in a part of the back, where is seen a splotch of dark tawny color. The tick found on the tiger is entirely of tawny color. I have had search made for lice on tigers, but these animals were apparently not infested by them, and the same can be said of all the leopards, lions, bears, wildcats, ichneumons, and other beasts, which according to ancient and royal custom, are maintained in the menageries of His Highness, the Grand Duke. I do not deny that they may be subject to vermin, but I simply affirm that the animals at present in the menageries are free from them, or else it may be that sufficient care was not exercised in looking for them, as meddling with lions and tigers is a business that few care to undertake. 
When I took up my pen I had in mind to write you a suitable letter, but having exceeded by far its limits, I know not how it has happened that I have almost written a book, and in a rather dry style devoid of grace. Hence I can with reason be blamed and cannot offer any defence, but I would not like to be censured for having given my opinion too frankly about certain statements of the most famous masters of this and past centuries; for every one is free to hold the opinion that he chooses, and I do not think that I have said anything prejudicial to the esteem and reverence which I bear them. On the contrary he, who is no tyrant, should not despise the liberty of procedure that obtains in the Republic of Philosophy, whose only aim is the search for truth, which, as Seneca said: "Omnibus patet, nondum est occupata; qui ante nos fuerunt, non Domini, sed Duces sunt; multum ex illa etiam futuris relictum est." I endeavor to gather up a small portion of this great remainder, and my only regret is that I am unable with my weak powers to produce results corresponding to the great opportunities granted me by the princely beneficence of my sole Lord, the Serene Grand Duke. But it may come to pass, or at least I hope so, that some day with increased knowledge and renewed strength, I may be capable of presenting to so grand a Patron something not entirely unworthy of his royal greatness. In the meanwhile, be assured that this letter or book, as you please to call it, has come to you not for praise but for correction, which I heartily beg you to give; being well aware that,

"My name unto the world is little known." 


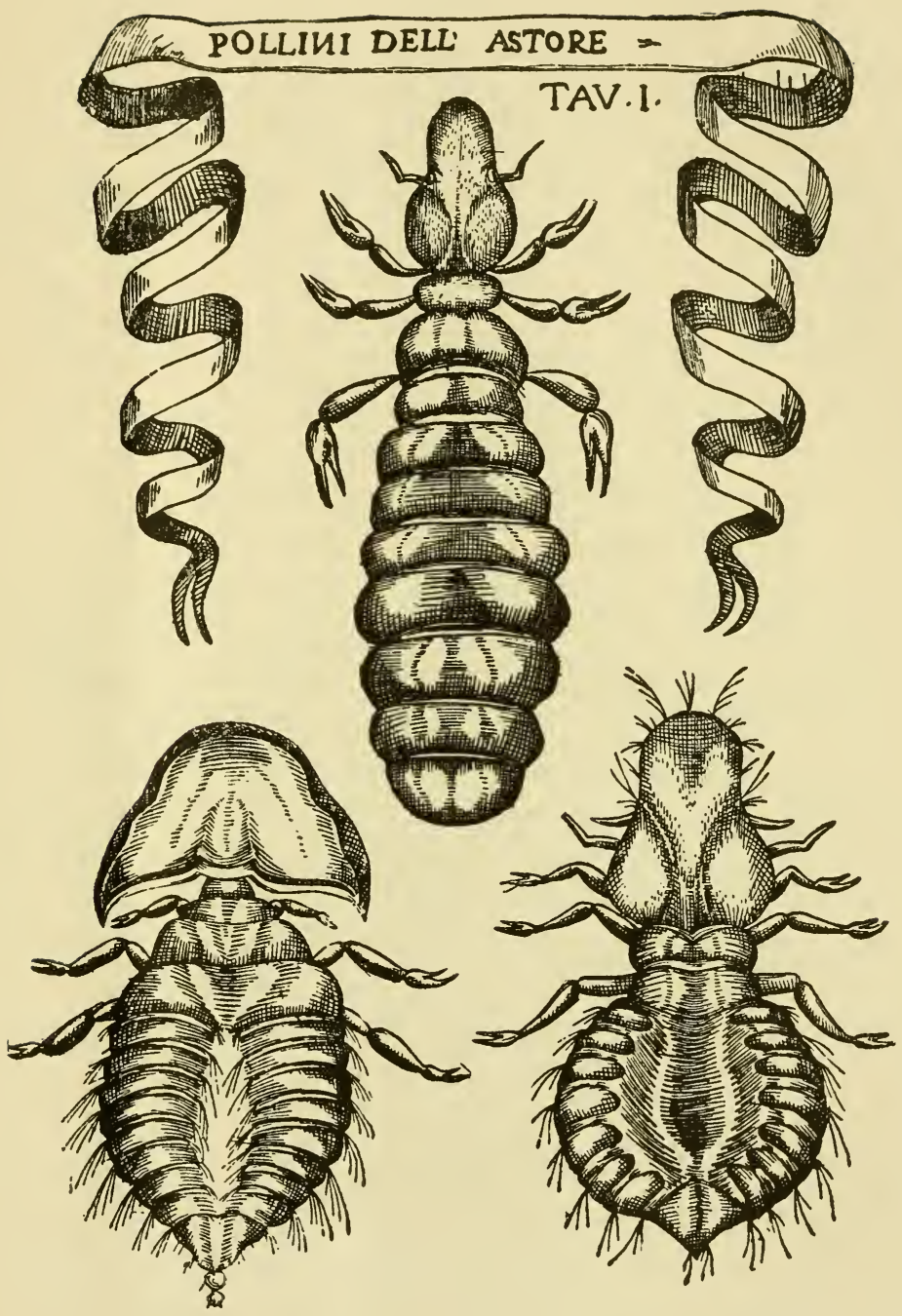




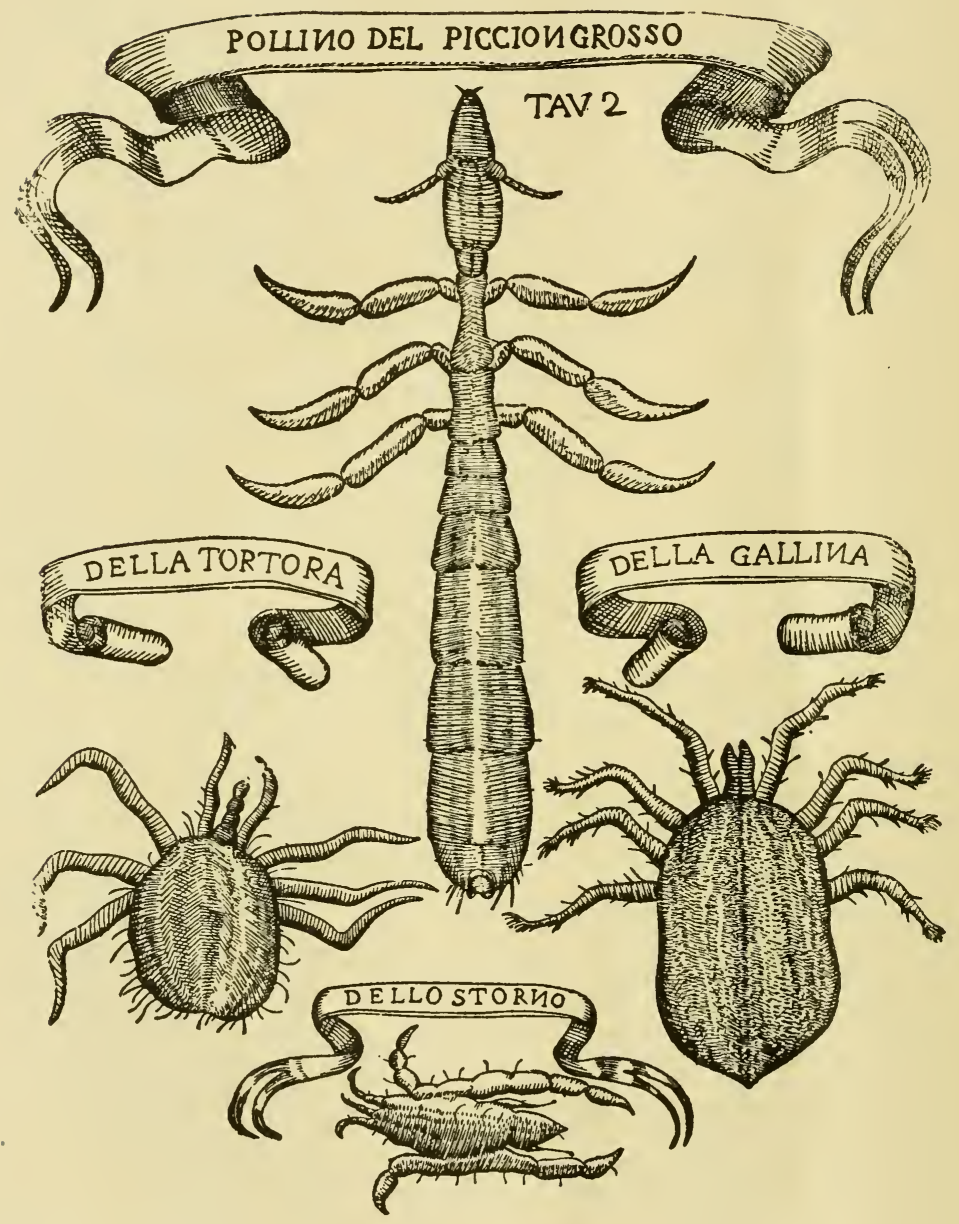




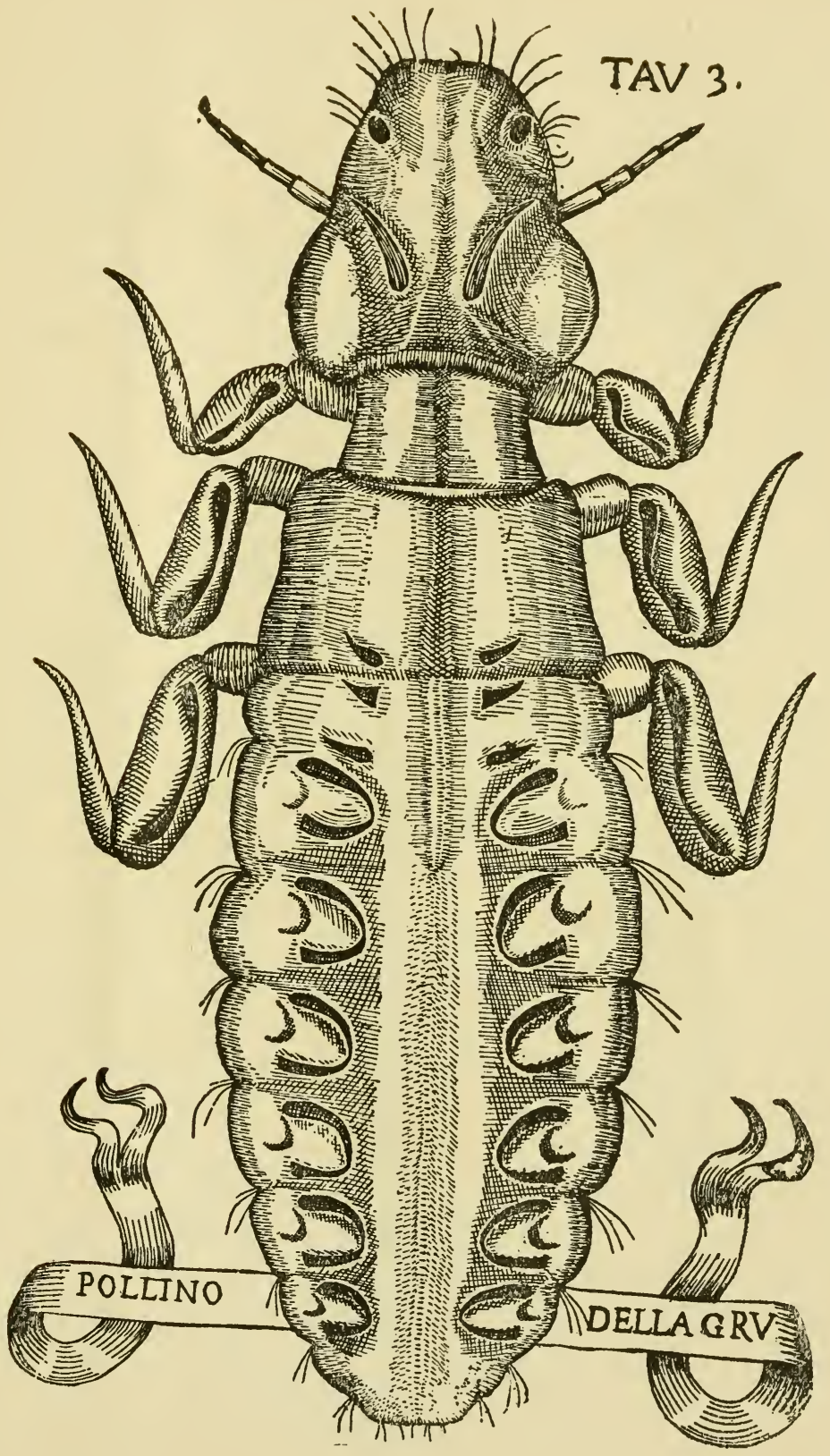




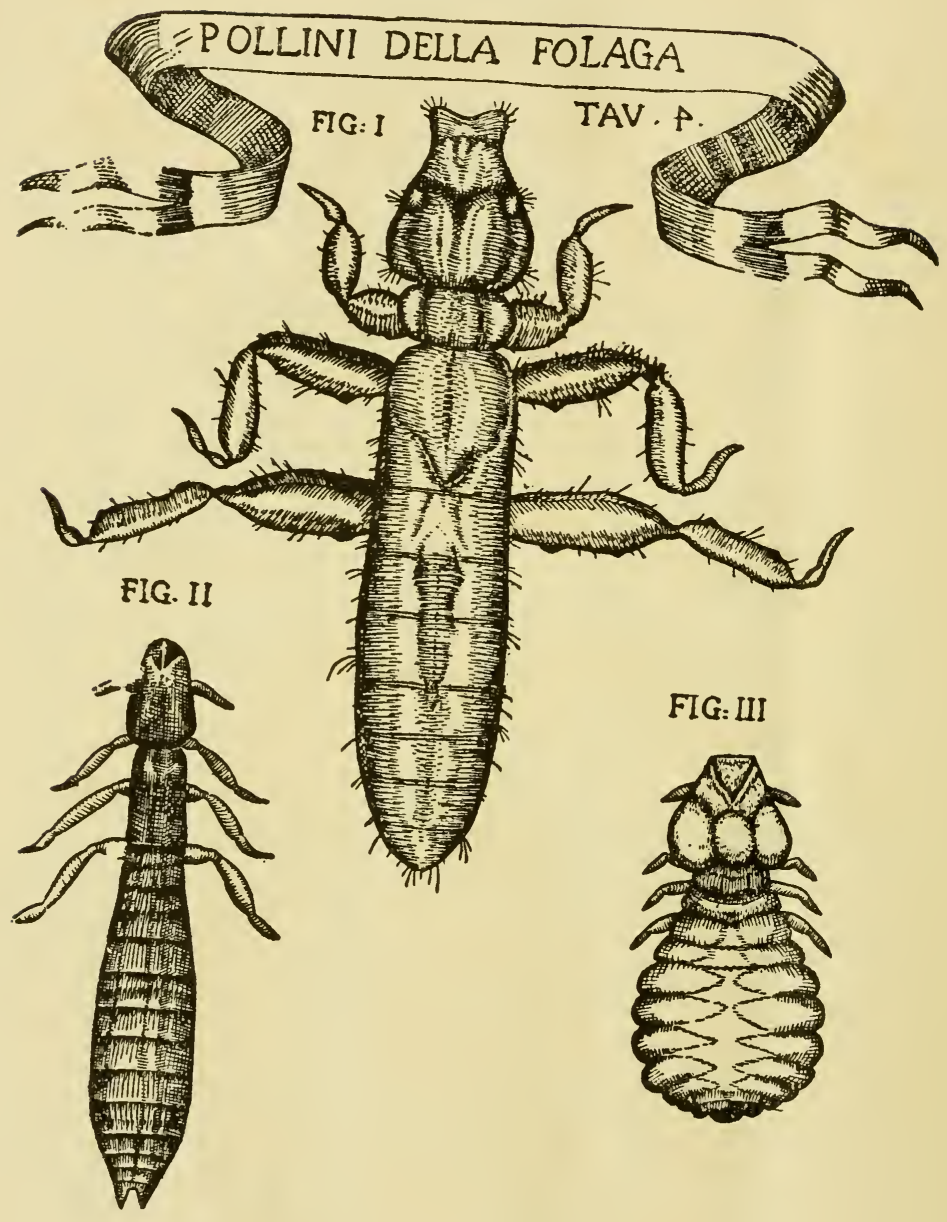



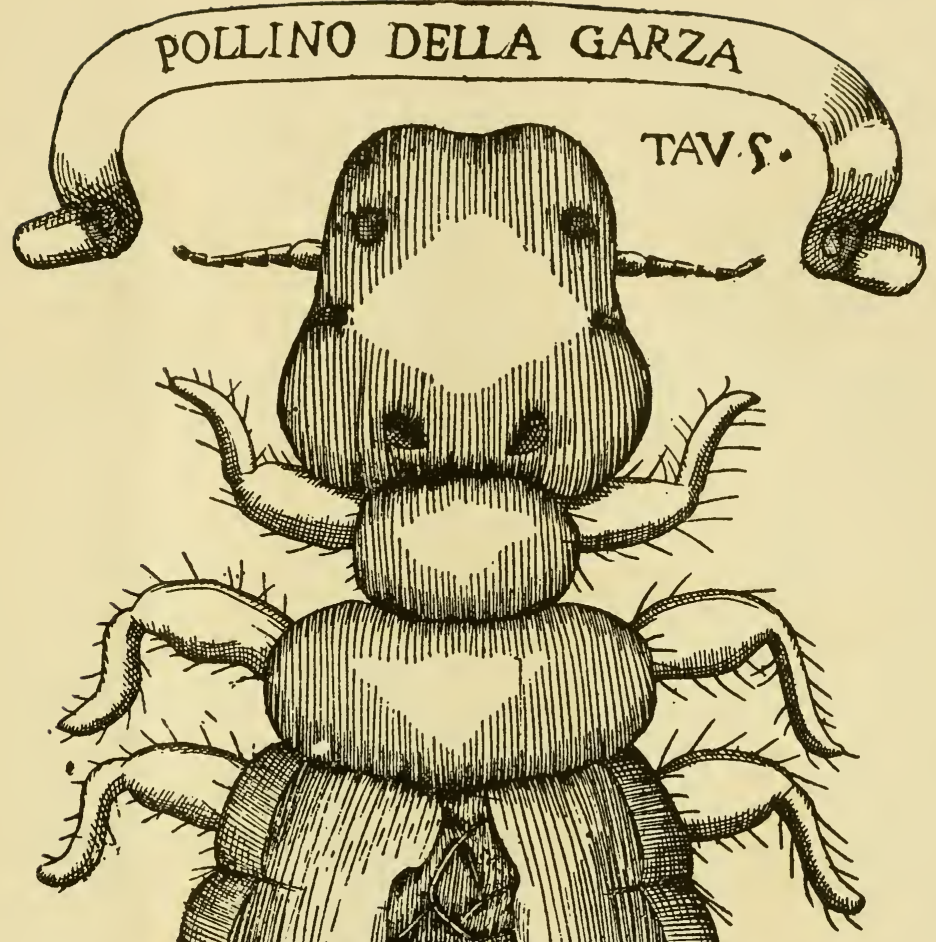


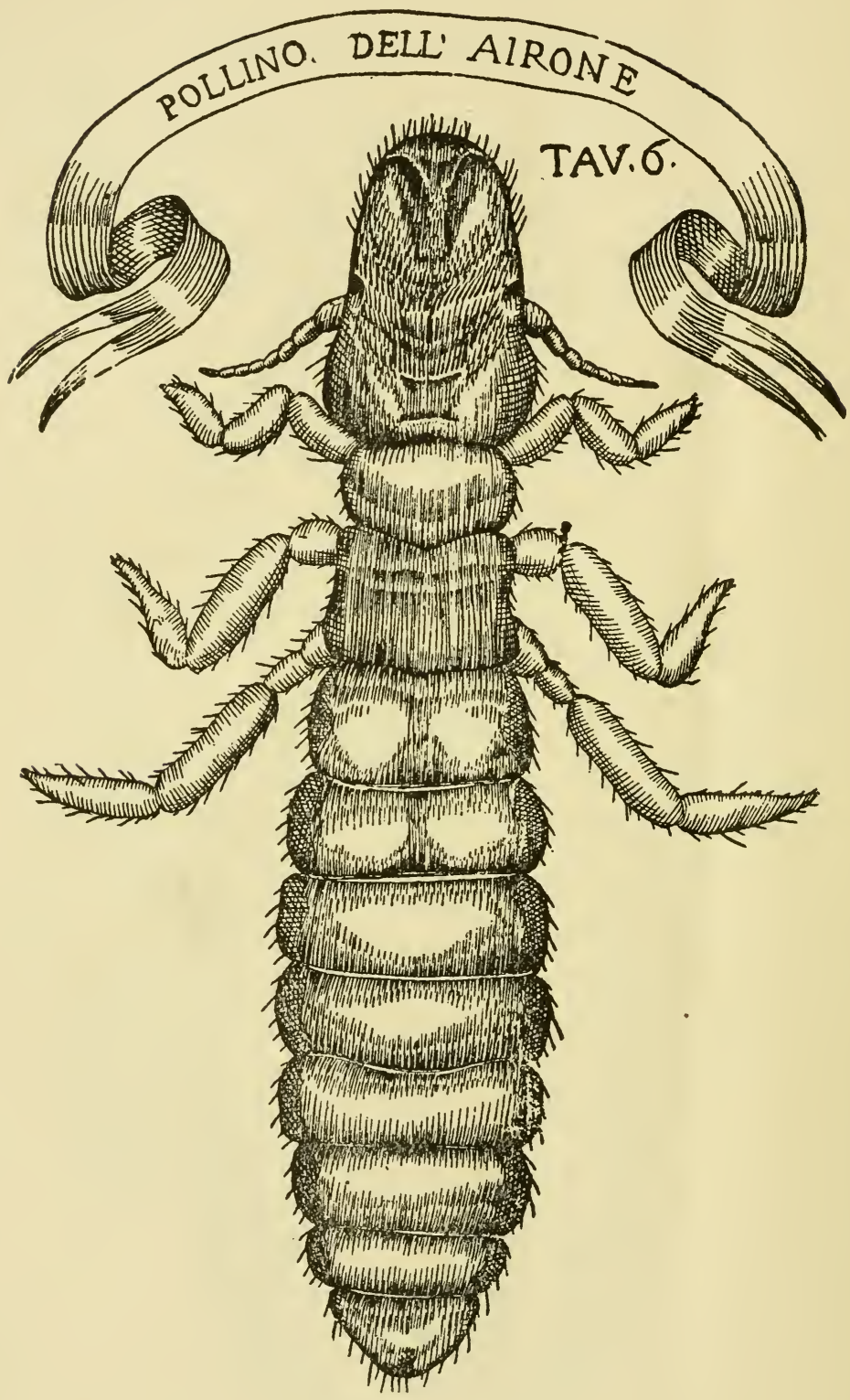




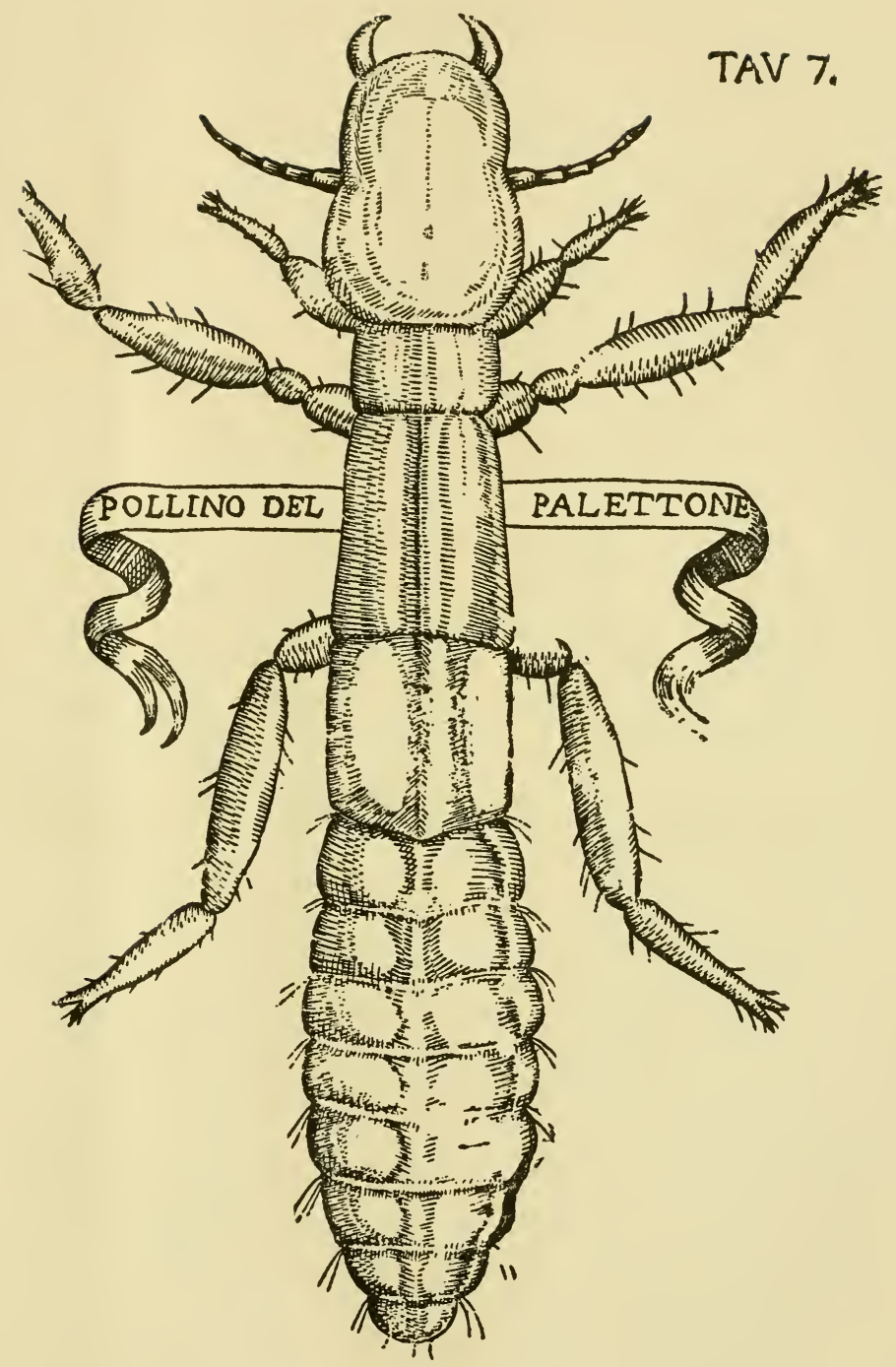




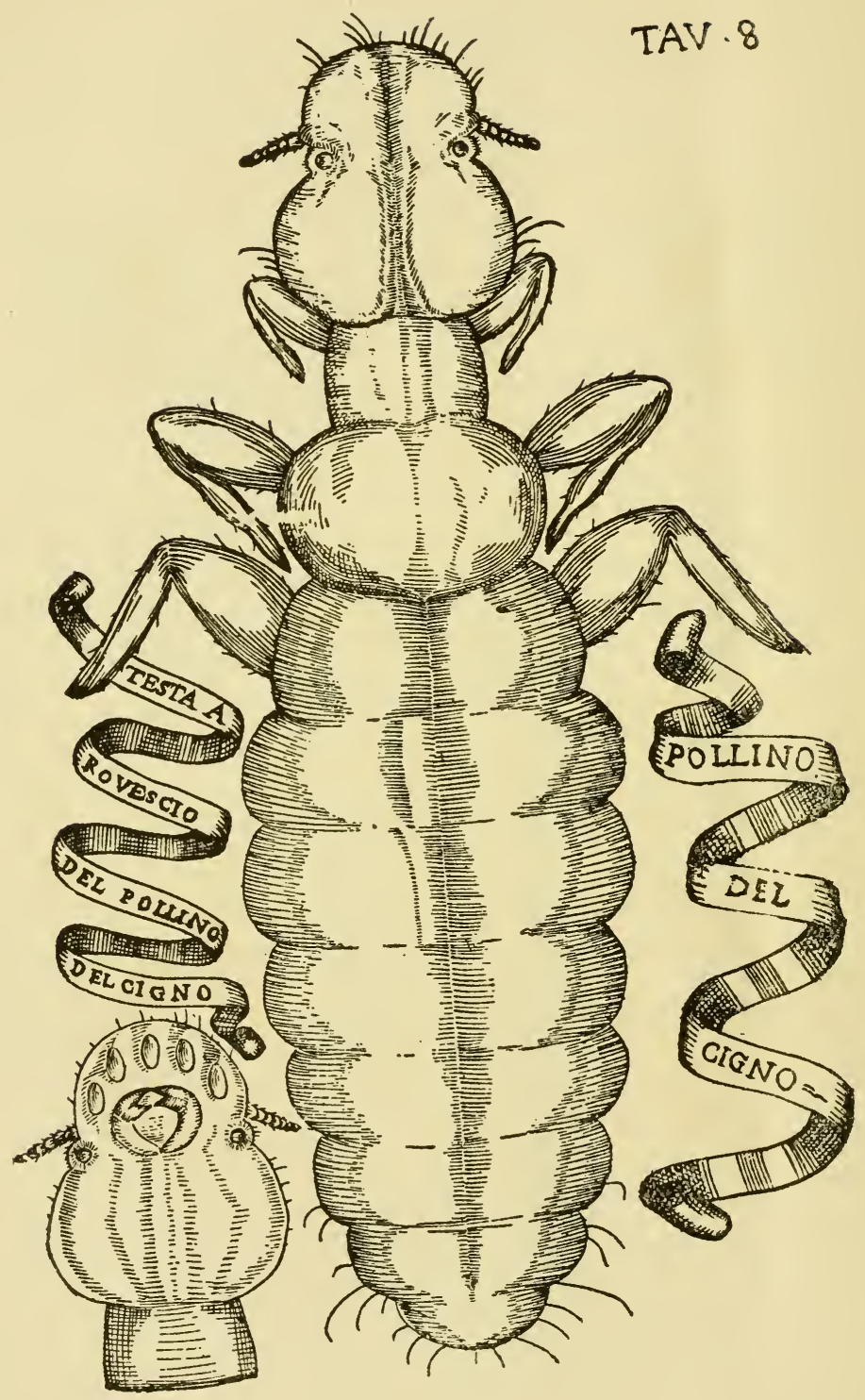




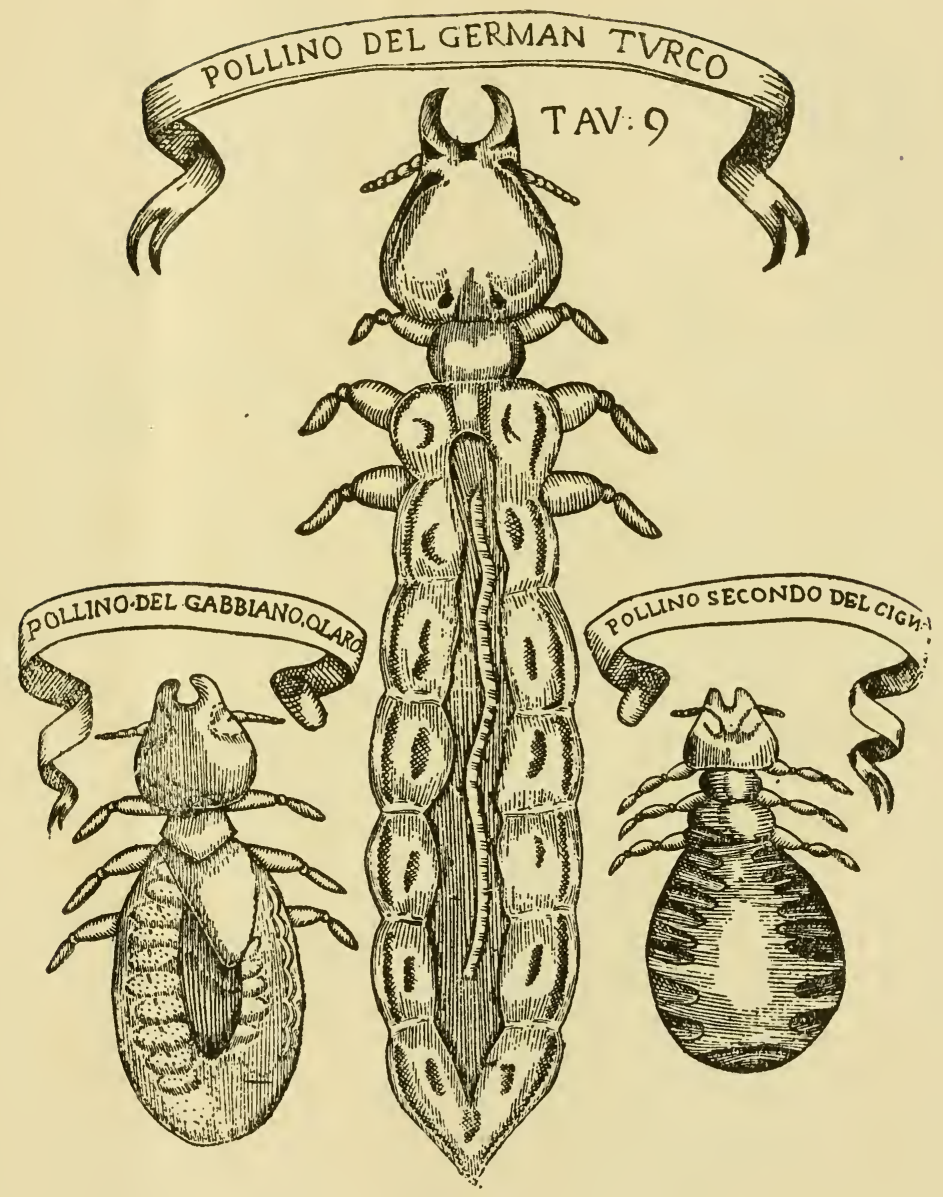




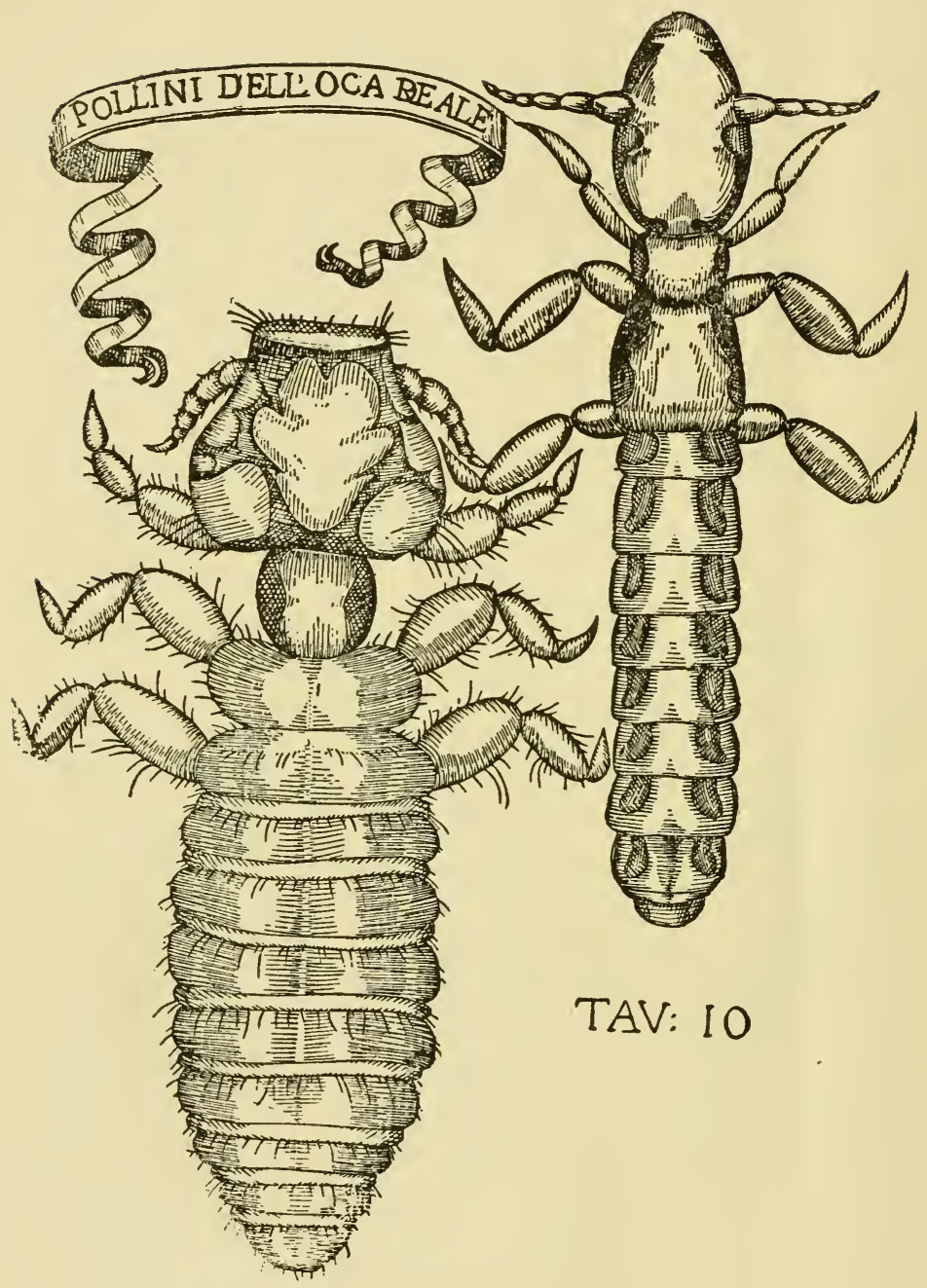




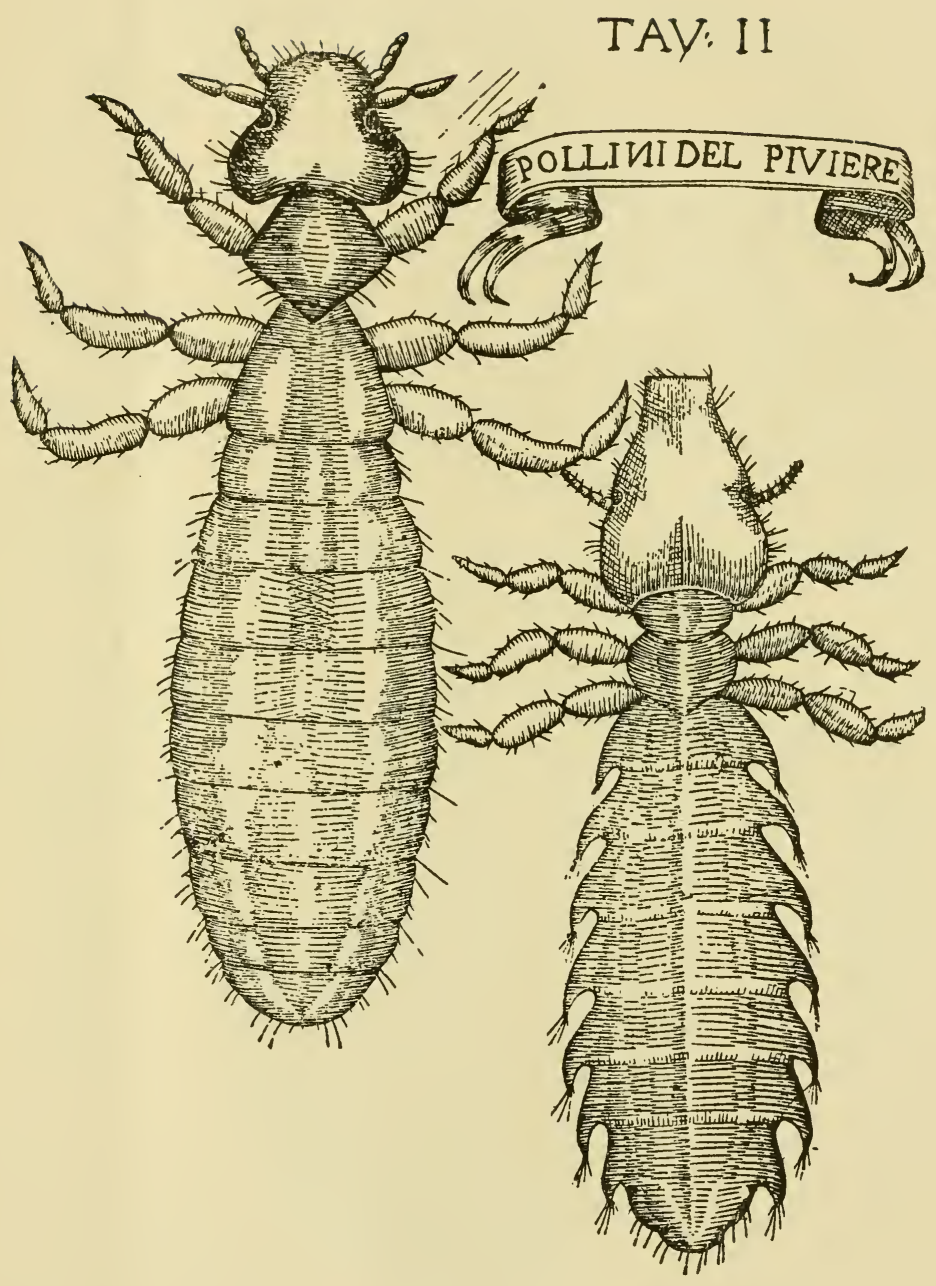




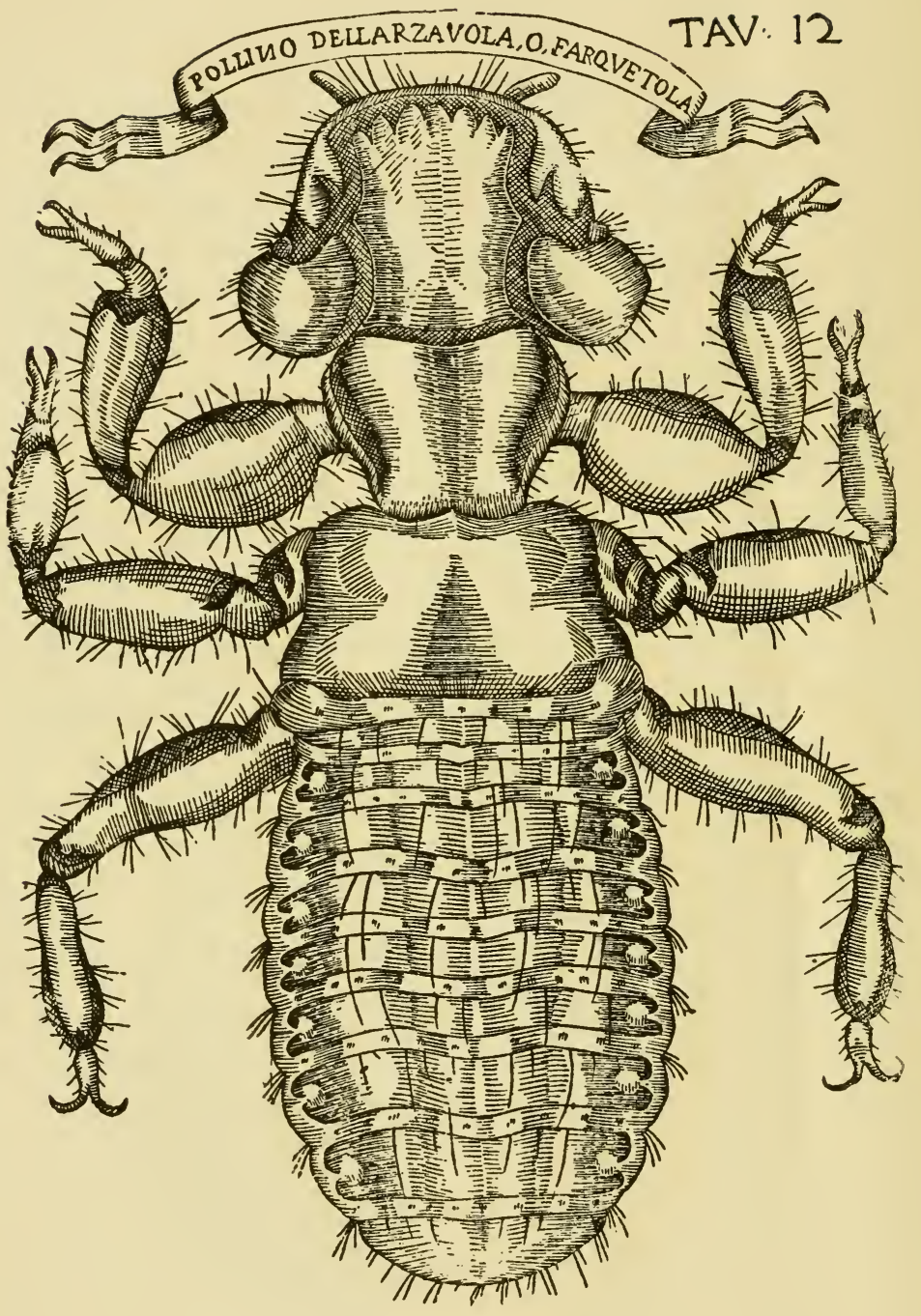




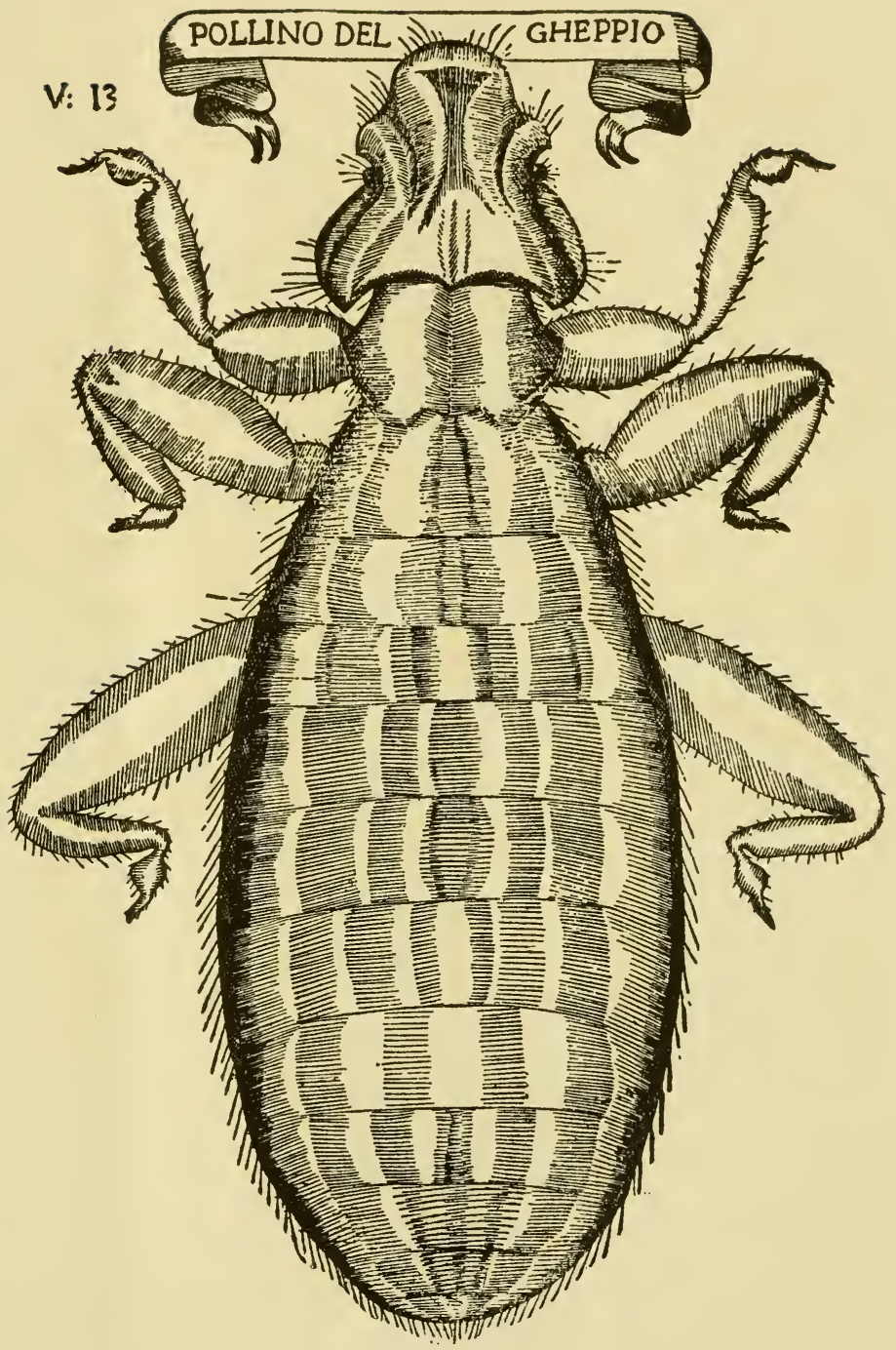




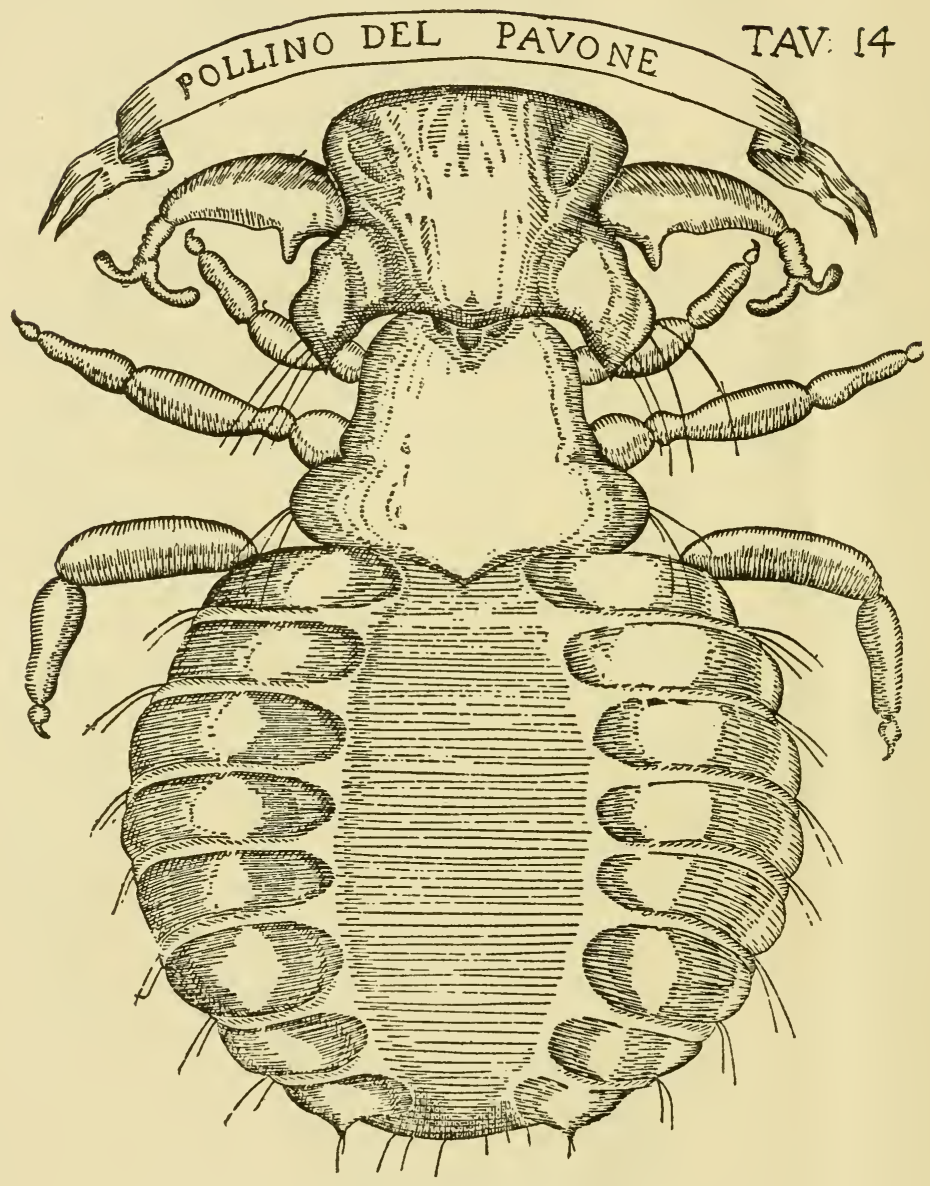




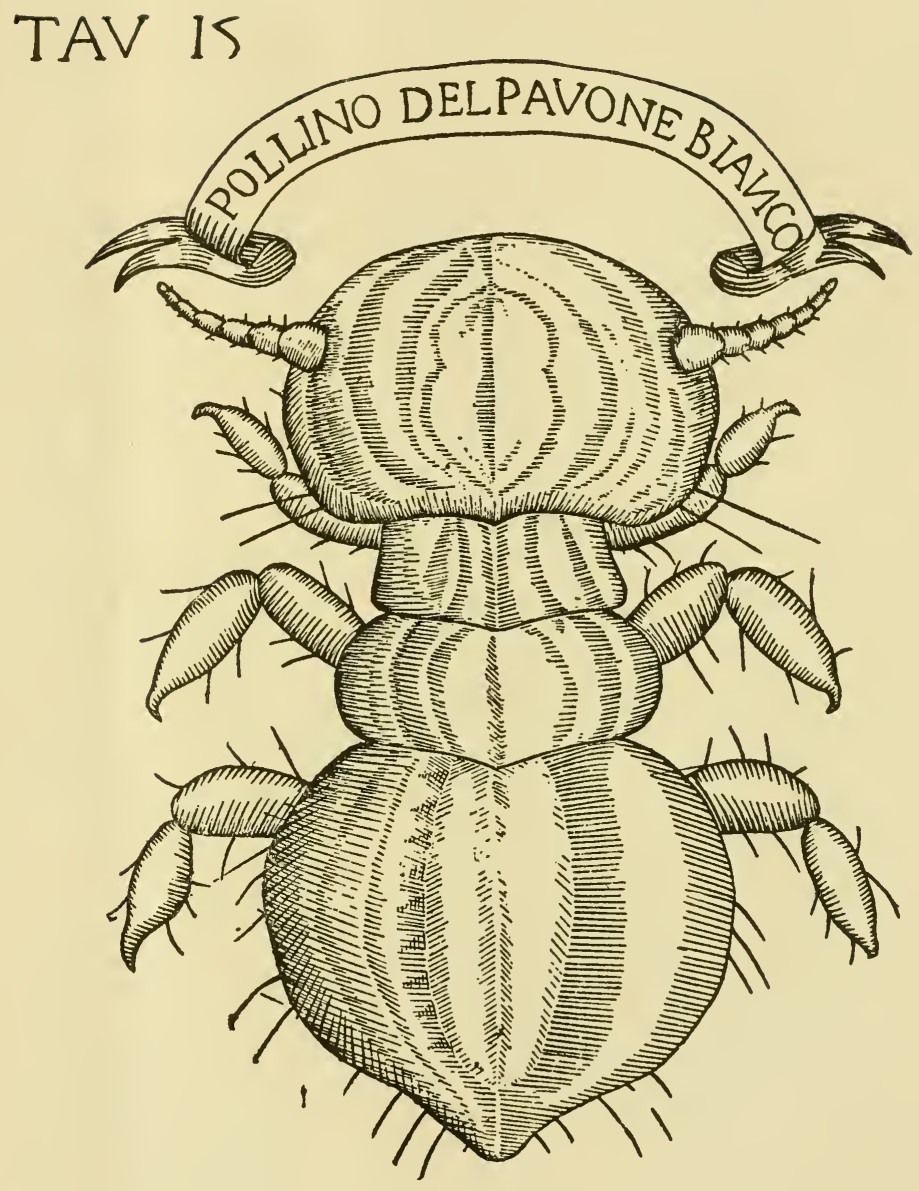




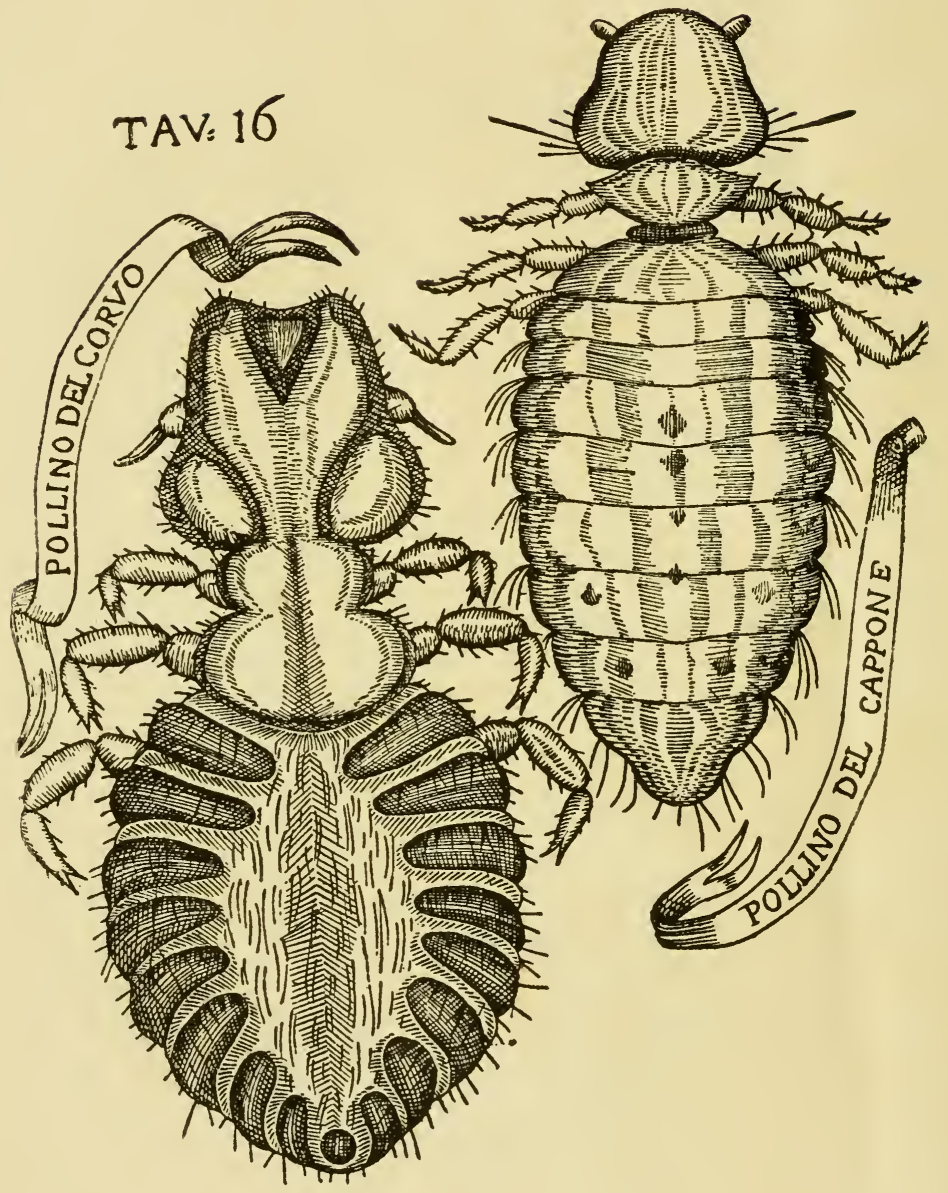




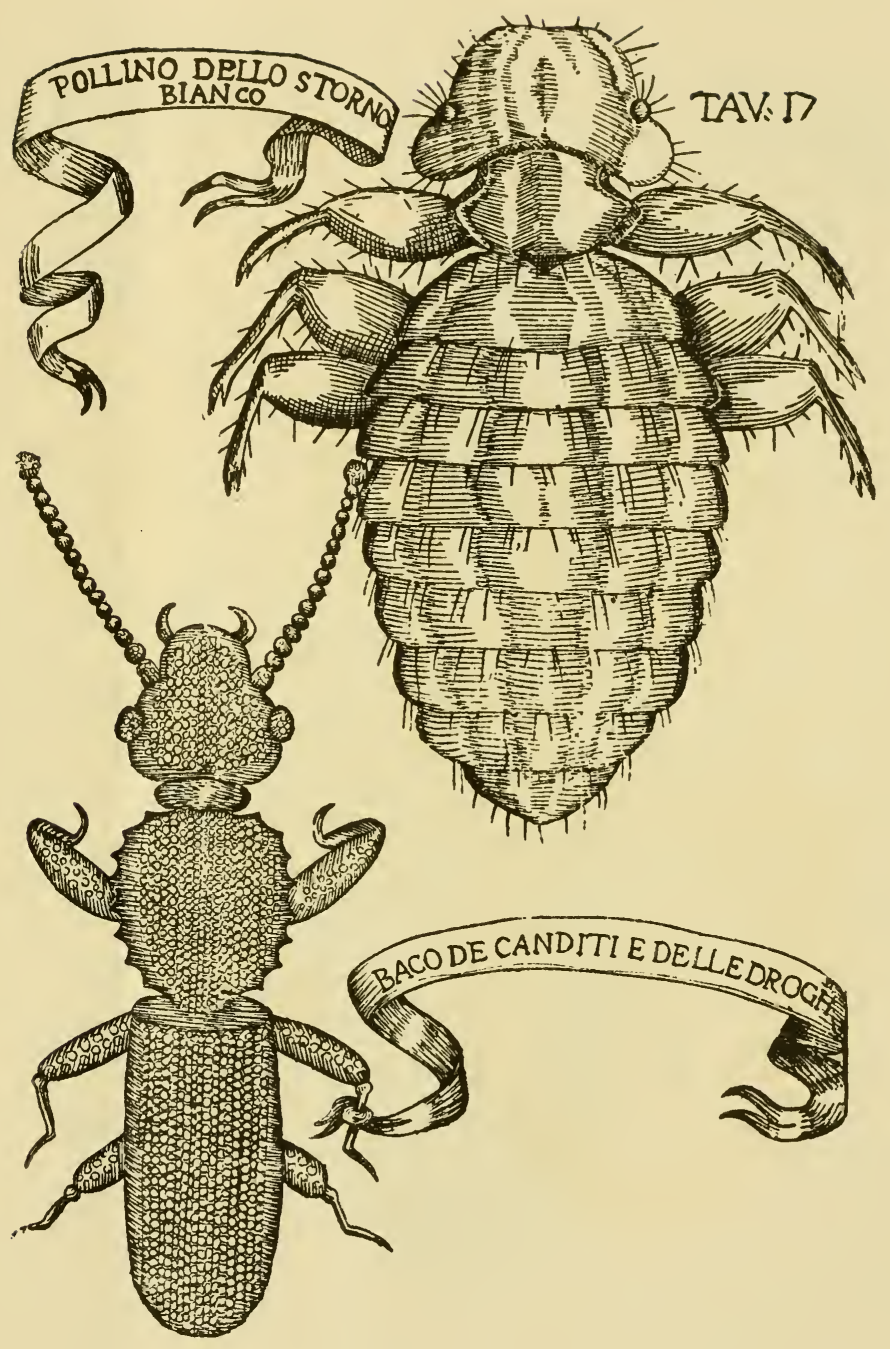




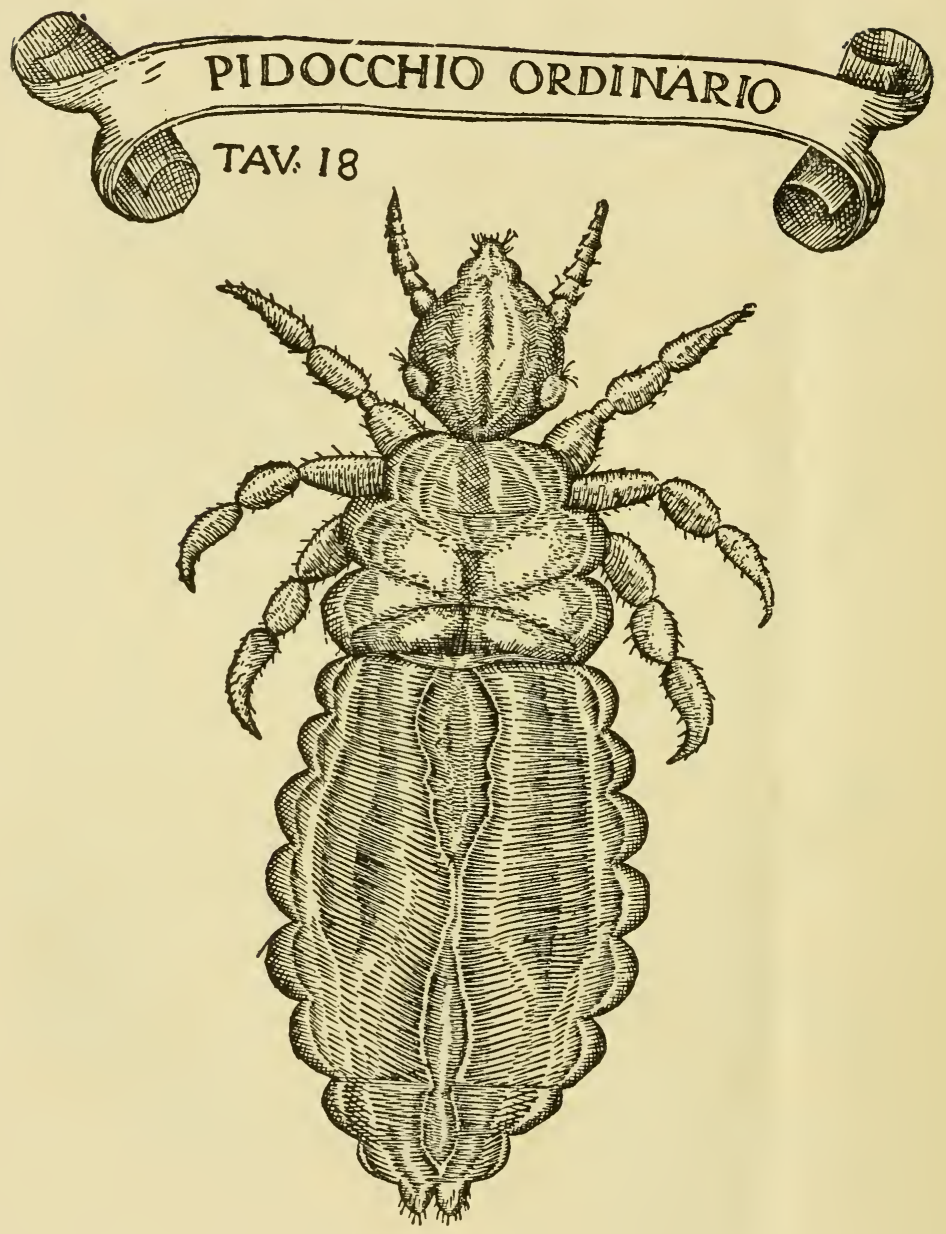




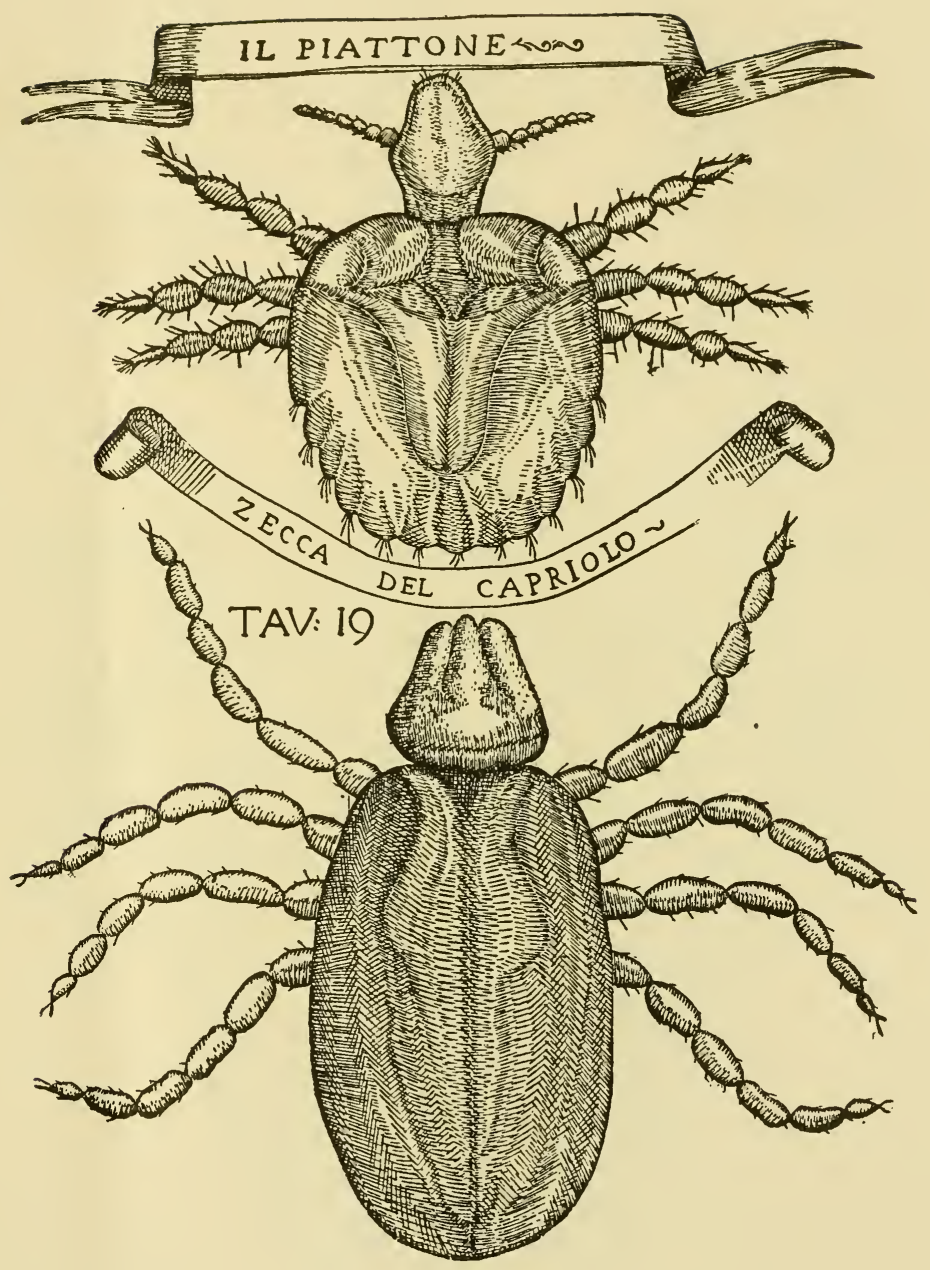




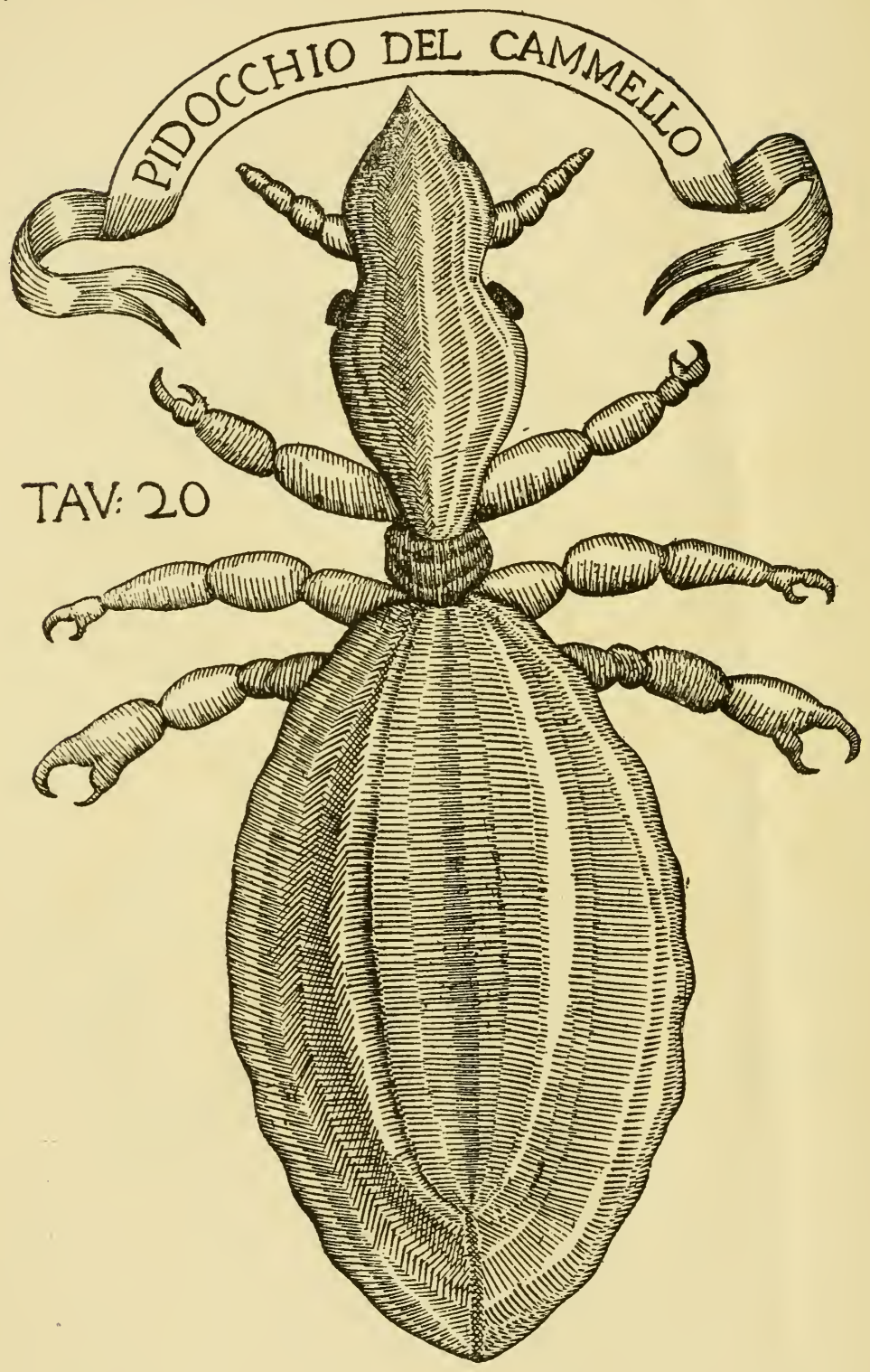




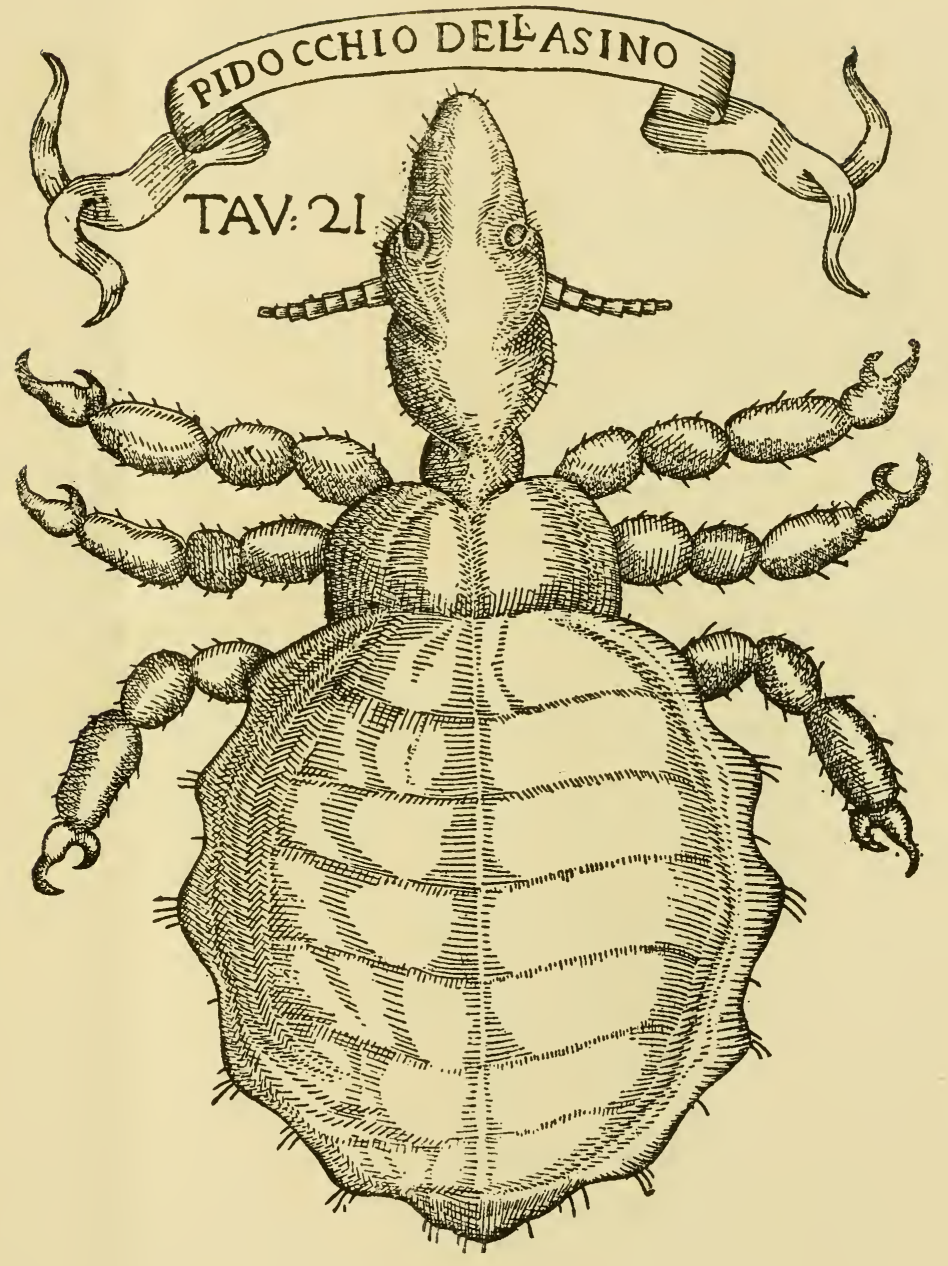




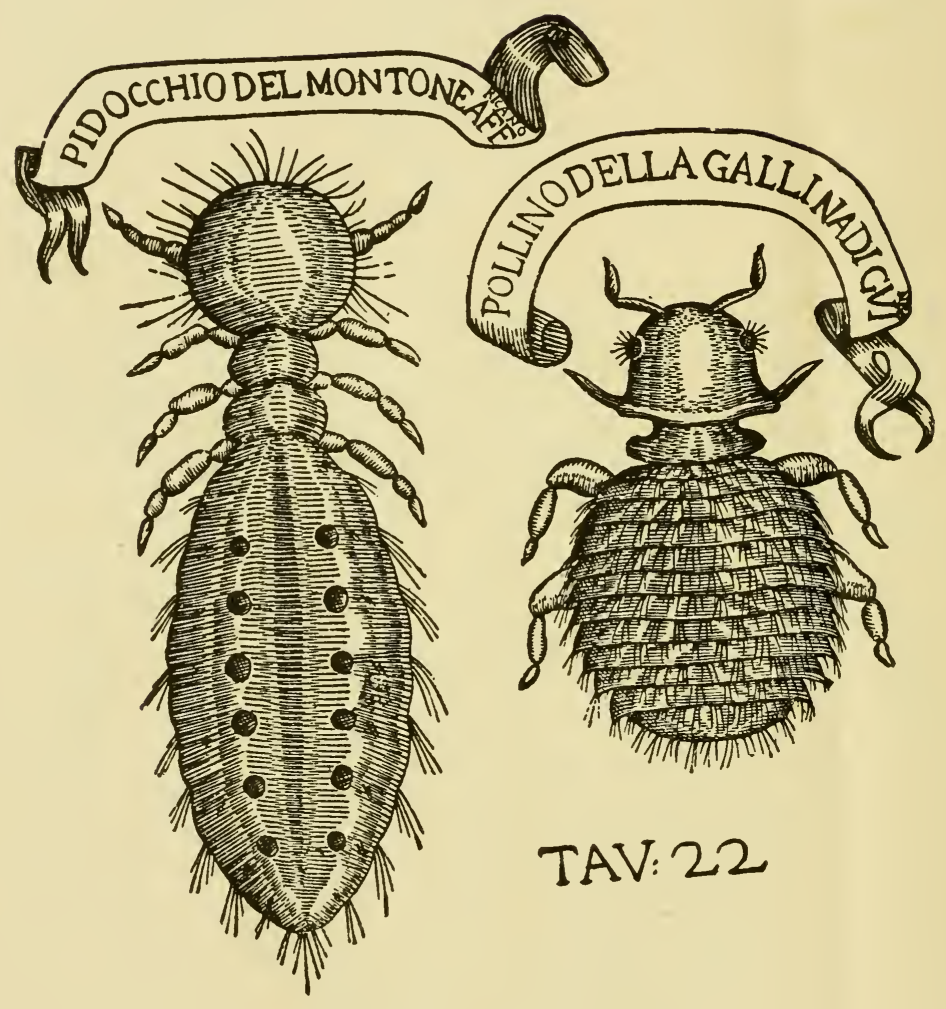




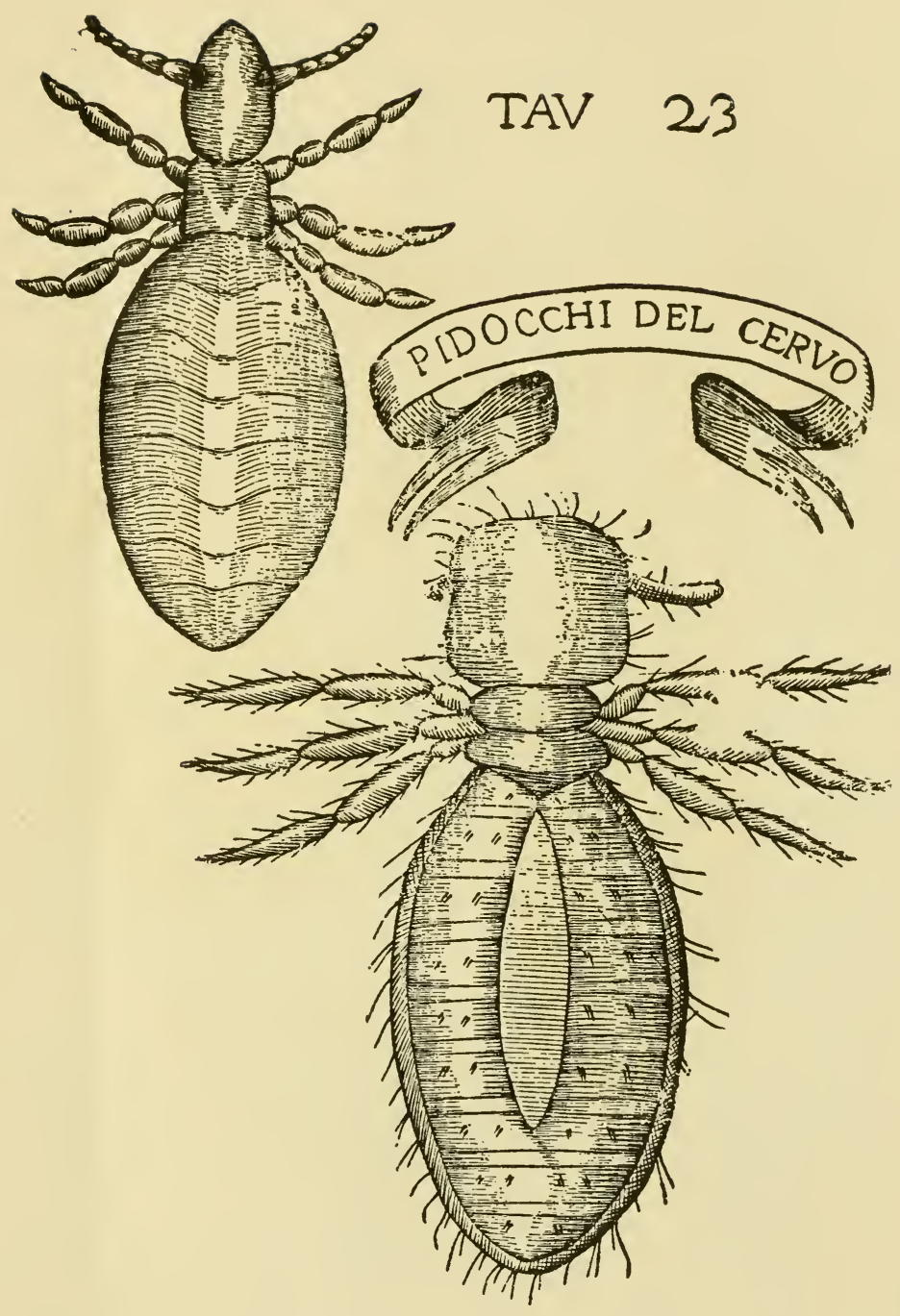




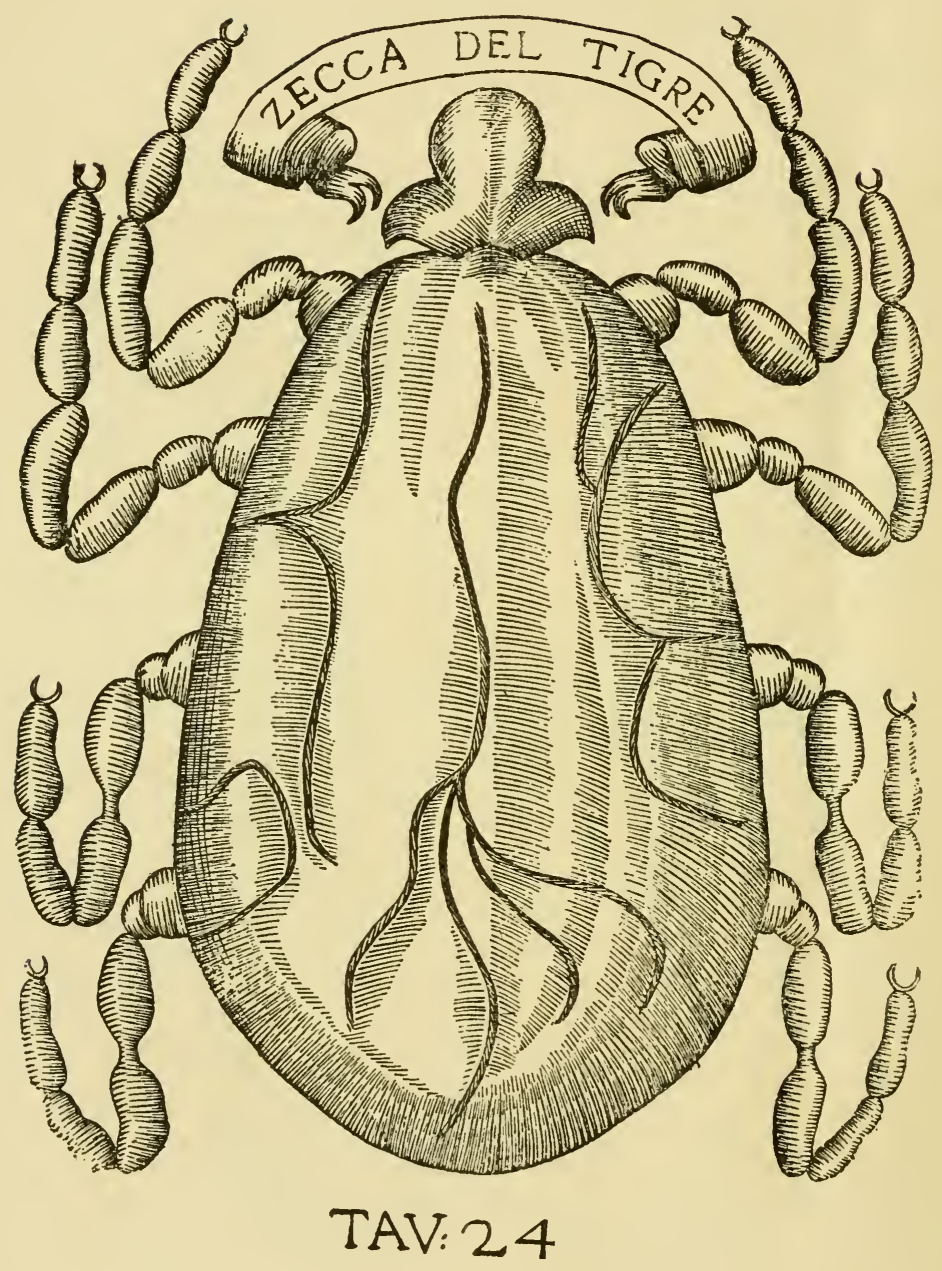




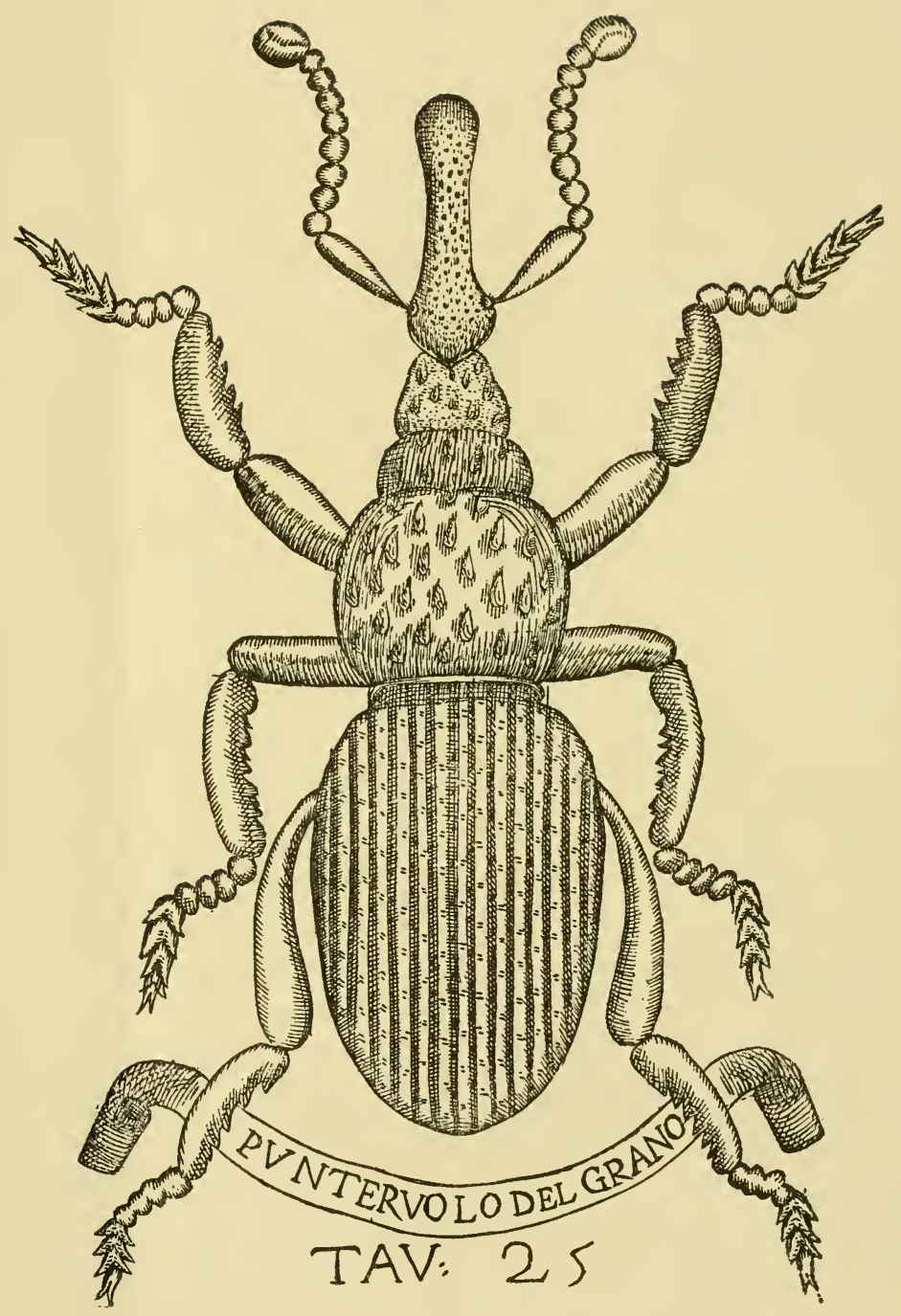




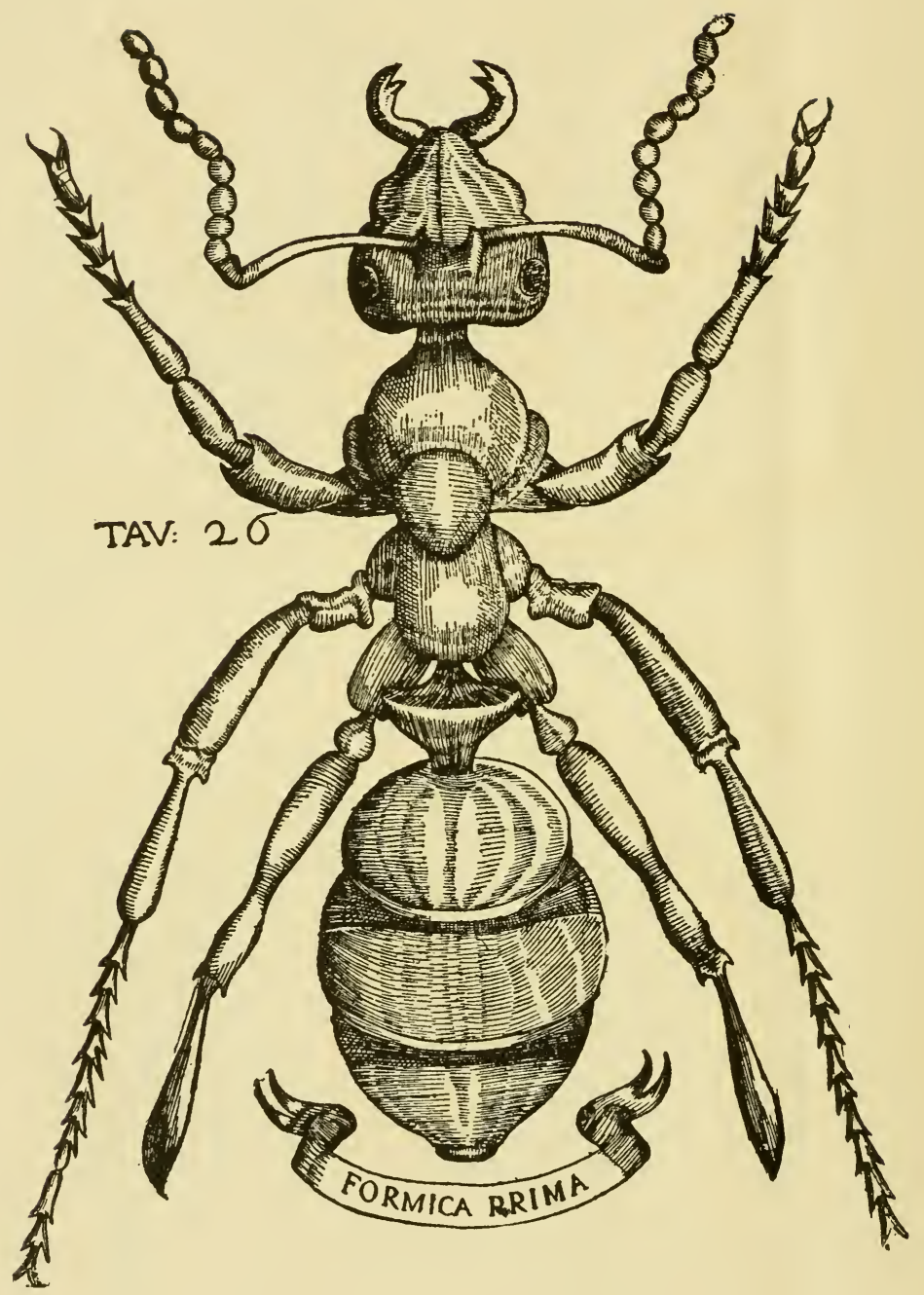




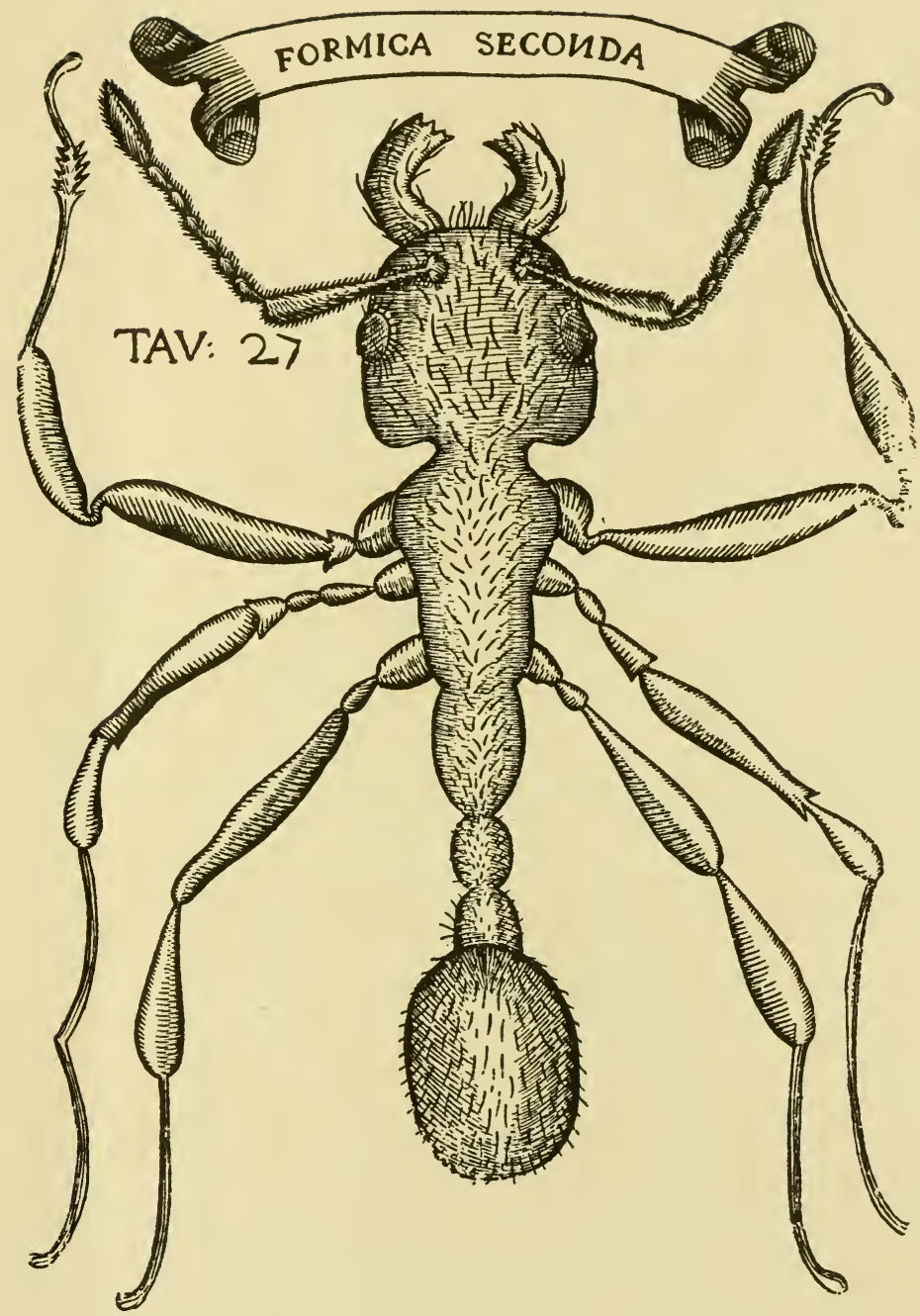




$$
\frac{\sqrt{80}}{D}
$$




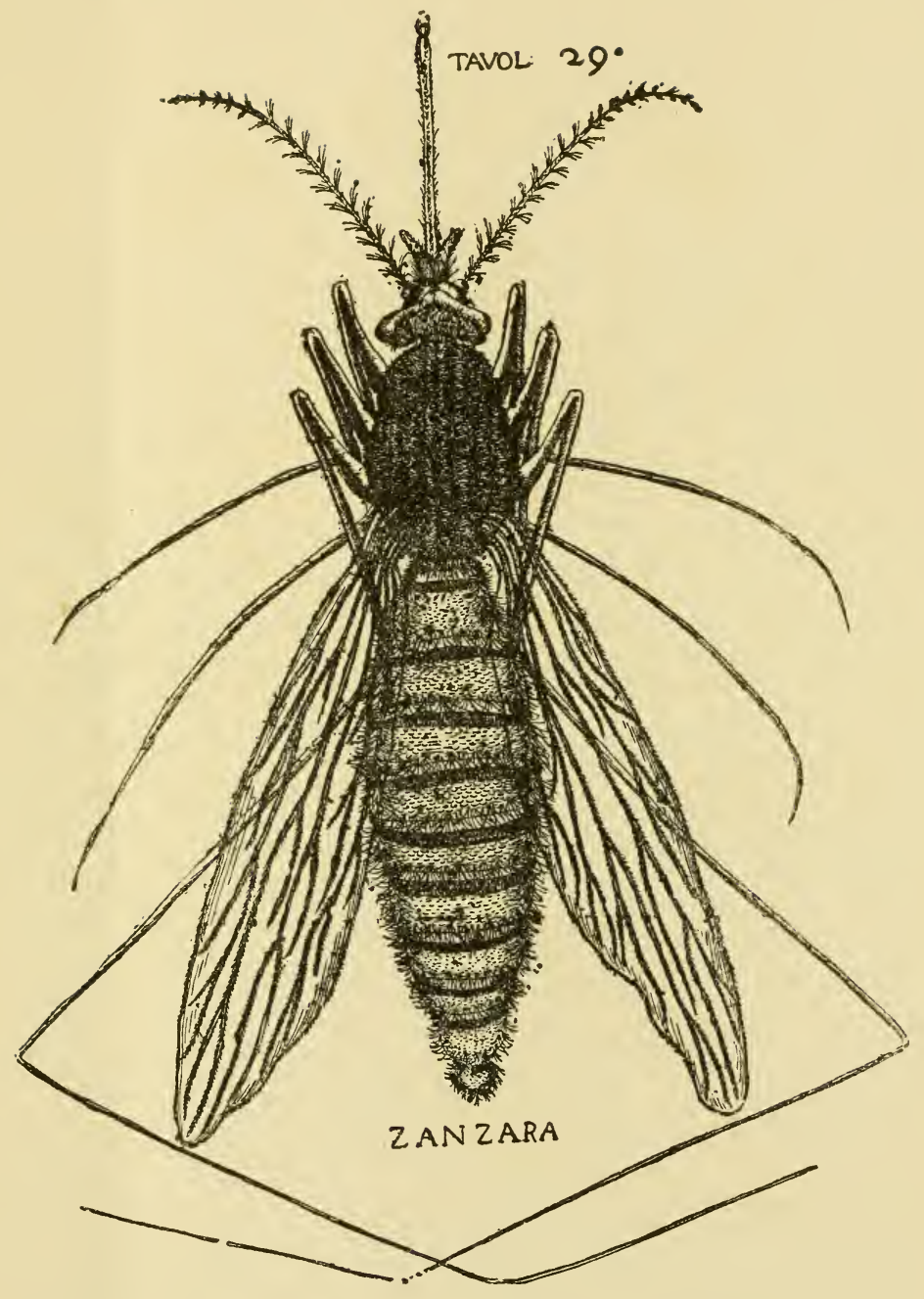





\section{INDEX ${ }^{1}$}

Elianus, 48, 65, 77

Air admitted to flask containing meat, 36

Aldrovandi, Ulysse, 43, 57, 65

Alfiruzabadi, Jacob, names lice in the Alcamus, 120

Anaxagoras, 96

Anaximander, 23

Anima, 9I

Anima mundi, 24

Antigonus Carystius, 38

Ants, parasites of, I2I

Archelaus the Athenian, 22, 42

Aristotle stated that nits do not produce animals, lice, II9

Aristotle, 5, 46, 69, II3

Ascidian, 98

Atoms, 25, 9I

Barbary scorpions, 57

Bark, eggs on, II3

Bartholin, Thomas, 43, 5I

Bees, 38-47, 49

Beetles, 50

Bellini, 7

Berni, poem by, 97-98

Bible, references to bees explained, 44-45

Bibliography, I3

Biogenesis, II, 26-27; dead animal and vegetable matter a breeding place for flies, 90

Bird lice, I23; see plates

Borelli, 7, 9

Bruno, 5
Butterflies, of plum, peach, and pear, 102 coition observed, I03; life historv, I03; of holm oak, I04; of nightshade, I04-I05; of oak, I05107; Ecdysis observed, 106; eggs laid, 106; unfertilized eggs do not hatch, 107; of cabbage, 107-108

Cabbage butterfly, I07-108; life history observed, II 3

Campanella, 5

Cannibalism of animals, 67

Caporali's verses on the life of Mæcenas, I 18

Cardano, Jerome, 43, 50

Carrion flies. 27

Caterpillars, 103-108

Celsus, 38

Cherry worm, 99-100, IOI

Cheese, old views concerning worms in, 73 ; experiments with, 74-75

Chrysalis, 106

Clematis, 85

Closed flasks, experiments with, 33

Cocoons, 103-106

Coition of flies, 74

Columella, 38, 39, 46

Cosimo III, Grand Duke of Tuscany, 6

Crabs, 36

Crescenzi, Pietro, 43, 47

1 Page numbers in italics indicate the position of illustrations. Most of the illustrations are reduced to about two-thirds the size of the original engrav. ings. Plate 15 is the same size. Plates $20-22$ and $25-28$ are reduced to about three-fourths, and Plates 13,26, and 29, to about one half. 
Dante, 20, 47

Dati, C., 7

Dead animals do not produce worms, 38

Decayed plants, insects in, 89

Democritus, 23, 96

Descartes, 9

Didymus, 46; in " Country-Life," speaks of lice, I20

Digby, Sir Kenelm, 36

Digestion, 73

Dioscorides, 89

Divini, Eustachio, maker of microscopes, 125

Dung, breeding place of flies and gnats, not bees, 43

Earth mother, 2I-24

Ecdysis, of caterpillar, I06

Eggs, of carrion flies, 31

Eggs laid by butterflies, II 3 ; on cabbage stalks, in the cracks of bark, on elder tree

Elder, caterpillars " on, parasitized, II 3 -I I5

Empedocles, 22, 96

Epicurus, 22

Evolution, early theories of, 2I24

Experimental method, 20-2I

Experiments: Carrion flies, 27; with closed flasks, 33; meat under ground, 34 ; with dead flies, 34 ; meat in gauze covered flask, 36-37; on the origin of scorpions, $5 \mathrm{I}$; toads proved not to arise from putrefying duck, 64 ; effect of oil on maggots, 65; drowning of flies, 65-66; with cheese, 74-75; with melon and pumpkin, 76

Explanation of plates, 125

Fabri, Honoré, 37, 44, 78

Feeling and motion, 99

Filbert worm, I00-I0I

Filicaja, 6

Fiorentino, 40

Flies, 27; viviparous, 37 ; ovaries, 38 ; bred in tun-fish, 66 ; breed in dung, 43; cheese flies, 74-75; coition observed, 74

Folli, Francesco, inventor of hygrometer, 43

Frogs, 77-80; sudden appearance after rain explained, 80

Fruits, secondary purpose, 92

Fungi, worms in living fungi, 90

Galen, 26, 39, 57

Galileo, 5, 9

Gall, insects, 109-110, I I ; willow galls, II2; Kircher

Galls, 70, 92-95; peculiar insects, 94 ; differ in times of maturity, 94

Gassendi, Pierre, 42, 73, 9I

Generative principle, 73, 91, 92

Gnats parasitic on carrion fly larvae, 32

Gnats, breed in dung, 43

Gottigniez, 7

Grembs, Francis, 43

Hair snakes produced from women's hair, according to Avicenna, 64

Harvey, W., 9; all living things born from seed, 24-25

Heart of snake, 8I

Heterogenesis in living plants, 9I-92, II6; tapeworms, botflies, II 6

Homer, 33

Hornets, eat meat, 47; poison not dependent on food, 48 ; feed on bees and flies, 49; originate in flesh of dead horses, according to Virgil and Ovid, 50

Houillier, Jacques, 52

Ichneumon-fly, IIA

Insects, 23; killed by oil, 65: when really drowned can not be revived, 66 ; in decayed plants, 89

Isopod? (Arcturus?), 122

Jesuits, 5

Johnston, John, 43

Kepler, 5

Kiranis, 64 
Kircher, Athanasius, 7, 34, 43, $64,8 \mathrm{I}$; experiment on frogs, 78-79

\section{Lactantius, 2I}

Liceto, Fortunio, 43, 52, $9 \mathrm{I}$

Lifeless bodies incapable of producing anything without insemination, II5

Low and high, terms unknown to Nature, 95

\section{Magalotti, 7}

Maggots hatched from eggs, 3 I

Maggots, 38

Magone, 38

Malice never found in animals not endowed with speech. 48

Manicheans, 96

Mantis, 88,89 ; two color-varieties, 85 ; external structure, 85 ; ecdysis, 86 ; internal structure, 86; eggs, 86. 88,89 ; grafting experiment, 87

Marchetti, 7

Marine animals, parasites, I2I

Mattiuoli, 52, 70

Melon, 76

Menagio, 49

Menzini, 6

Metamorphosis, 106

Moufet, Thomas, 43, 44, 47, 68, $7 \mathrm{I}$; reports on parasites of beetles, I2I ; Theatrum Insectarum, I 20

Nicander, 42

Oeffer, Wolfgang, 52

Olimpiodorus, 50

Origen, 42

Oro, 50

Osier, berry-like growths, 108

Ovaries of flies, 38

Ovid, 39, 42, 50, 5I, 77

Paracelsus, 36

Paralysis, 99

Parasites, II6; liver fluke; botflies, I17, I18; Aristotle de- scribes worms in deer's head, II7; of caterpillars, II3-II5; of maggots, 32

Pizzichi, F., 124; drawings of lice

Peach, worm in, $\mathrm{IO}_{2}$

Pear, worm in, 102

Philas of Tarsus, 42

Philo the Jew, 42

Philosophy, I26; only aim of philosophy is the search for truth, 126; Seneca, I26

Philes, Manuel, 46

Philetas of Cos, 4I

Pisida, George, 36, 42

Plant-animals, 96, 98-99

Plates, lice of the falcon, 127 ; louse of the large pigeon, turtle-dove, louse or mite, hen-louse, or mite, louse of starling, I28; louse of the crane, I29; lice of the moorhen, figures, I, 2, 3, I 30 ; louse of the white-heron, egret, I3I; louse of the black-heron, I 32 ; louse of the spoon-bill, I33; louse of swan, head of swan-louse under view, I34; louse of wild-duck, louse of sea-gull, mite of the swan, 135; lice of the wild-goose, 136; lice of the plover, I37; louse of the kestrel, I39; louse of the peacock, I40; louse of white peacock, I4I ; louse of the crow, louse of the capon, I42; louse of the white starling, worm found in citron and spice, I43; common louse, I44; crablouse, tick of wild-goat, I 45 ; louse of camel, I46; louse of the ass, I47; louse of African sheep, louse of Guinea-hen, I48; deer lice, I49; tick of the tiger, I50; grain weevil, I5I; ant, I52; ant, 2, 153; ant, 3; shaggy. I54; mosquito, 155

Plato, 96

Pliny, 18, 38, 46, 47, 50, 51, 52, $69,65,76,77,90$ 
Pliny exempts asses and sheep from lice, I20

Plotinus, 96

Plum, worm in, 102

Plutarch, 42

Porta, Battista, 50, 52, 64

Purpose, 92

Putrefaction, 9I

Pythagorus, 96

Pumpkin, 76

Pupæ, 28

Redi, F., life of, 5-8; significance of his work, 8-II; bibliography, I3; belief in biogenesis, 26-27

Rucellai, Giovanni, poem on bees, 40-4I

Sachs, Philip James, 5I

Saint Jerome, 57

Scaliger, 37

Scorpions, 63; myths concerning spontaneous generation of, $5 \mathrm{I}-53$; this theory disproved, 53 ; sexual differençes, 53 ; habits of young, 54 ; position of young in oviduct, 54; abundance in Italy, 55; Italian species compared with forms from Egypt and Tunis, 55-57; weight, 55; aperture of sting, 58 ; poison, its effects, 58-62; flies breed in dead scorpions, 64

Segneri, 7

Seneca, quotation, 126

Senses, their use as a guide to reason, I9

Sensibility of plants, $96-98$

Servius the grammarian, 50

Silkworms, II 5 ; Vida's origin of same in decayed flesh of mule, II 5

Snakes, 27, 49; belief in creation from rotten matter utterly false, 64 ; heart has one ventricle, 8I

Soul, as generative principle, 9I, 92

Sperling, Johann, 37, 43, 65, II9
Spiders, ability to withstand starvation, 66; eggs, 67, 69; young, 67 ; ecdysis, 68 ; nest, 69 ; thread, 69; do not live in galls, 70; web, 7I-72

Sponges, plant-animals, 96; movement, 99

Spontaneous generation, 9, 9I

Spontaneous generation, early belief in, 2I; flesh does not become wormy of itself, 72 ; does not occur in protected fruits and vegetables, 75; does not occur in dead animals, 38 ; in dead flesh denied, 64

Stoics, theory of origin of man, 22

Sweet basil, belief that scorpions are produced by it disproved, 52

Tachinid fly, II4

Tadpoles, 79

Tertullian, 57

Theophrastus, 48

Toads, 64 ; appearance during a shower, explained, 80

Tumors on plants, 8I, 85, 82-84 (see also Galls)

Tun-fish, 65

Turtles, method of laying eggs, 78

Uterus, use of the term, 69

Vallisneri, Io

Varini, 5

Varro, 26, 38, 39, 46, 50

Vida, Girolamo, II 5

Virgil, 39, 42

Vital stimulus, 94

Voss, Gerard, 43

Wasps eat meat, 47 ; poison not dependent on food, 48 ; attack bees and flies, 49; feed on fruit and flowers, 49; originate in flesh of dead horses, according to Varro, 50

Whitethorn, 85

World soul, 24

Zoophytes, 96, 98-99 



